\title{
Revision of the Neotropical genus Triportheus Cope, 1872 (Characiformes: Characidae)
}

\author{
Maria Claudia S. L. Malabarba
}

\begin{abstract}
The genus Triportheus Cope, 1872 is revised and a total of 16 species (including 3 new species) are recognized from most of the major river drainages of South America. Triportheus magdalenae (Steindachner, 1878) is the sole species occurring west of the Andean Cordilleras. Triportheus paranensis (Günther, 1874) is considered a junior synonym of Triportheus nematurus (Kner, 1858) and a new Triportheus species is described for the río Paraguay basin. Chalcinus rotundatus iquitensis Nakashima, 1941 and Chalcinus elongatus iquitensis Nakashima, 1941 are placed into the synonymy of Triportheus albus Cope, 1872 and T. culter (Cope, 1872) respectively. The name Salmo clupeoides employed by Natterer (in Kner, 1860) is considered a nomen nudum. Neotypes are designated for Chalceus angulatus Spix \& Agassiz, 1829, Chalceus rotundatus Jardine in Schomburgk, 1841 and Chalcinus auritus Valenciennes in Cuvier \& Valenciennes, 1850. Lectotypes are designated for Chalcinus brachipomus Valenciennes in Cuvier \& Valenciennes, 1850 and Chalcinus nematurus. Identification keys are provided for the Triportheus species in the major drainage basins of South America.
\end{abstract}

O gênero Triportheus Cope, 1872 é revisado e um total de 16 espécies são reconhecidas (incluindo 3 novas) na maioria das grandes bacias hidrográficas da América do Sul. Triportheus magdalenae (Steindachner, 1878) é a única espécie ocorrendo a oeste da Cordilheira dos Andes. Triportheus paranensis (Günther, 1874) é considerado sinônimo junior de T. nematurus (Kner, 1858) e uma nova espécie de Triportheus é descrita para a bacia do rio Paraguai. Chalcinus rotundatus iquitensis Nakashima, 1941 e Chalcinus elongatus iquitensis Nakashima, 1941 são colocados na sinonímia de T. albus Cope, 1872 e T. culter (Cope, 1872) respectivamente. O nome Salmo clupeoides empregado por Natterer (in Kner, 1860) é considerado um nomen nudum. Neótipos são designados para Chalceus angulatus Spix \& Agassiz, 1829, C. rotundatus Jardine in Schomburgk, 1841 e Chalcinus auritus Valenciennes, 1850. Lectótipos são designados para Chalcinus brachipomus Valenciennes in Cuvier \& Valenciennes, 1850 e Chalcinus nematurus. São fornecidas chaves de identificação para as espécies de Triportheus das maiores bacias hidrográficas da América do Sul.

Key words: Characid, taxonomy, South America, fishes.

\section{Introduction}

The species of the characid genus Triportheus Cope (1872) inhabit most of the major river drainages of South America, and can be easily recognized by their expanded, keeled coracoids and large pectoral fins. Some species of the genus reach a moderate size (200-240 mm), constituting an important element in both commercial and subsistence fisheries. In the Amazon basin, Triportheus is among the fishes most often consumed by humans (Queiroz \& Crampton, 1999). Triportheus species have relatively weak dentition and their usual food items include seeds, plankton, and small invertebrates. In poor oxygenate water, they are able to develop barbels on the lower lips that serve to direct the superficial oxygenate water into the mouth.
The first described species of the genus was Chalceus angulatus proposed by Spix and Agassiz (1829) based on specimens collected by the Spix and Martius expedition in Brazil from 1817 to 1820 (see remarks under that species). The next species to be described, also in Chalceus, was $C$. rotundatus Jardine (in Schomburgk, 1841). Subsequently, Valenciennes (in Cuvier \& Valenciennes 1850), citing the differences between $C$. angulatus and the other species of Chalceus, created a new genus, Chalcinus, to include Chalceus angulatus and two new species, Chalcinus brachipomus and C. auritus, described in the same publication. Most of the Triportheus species described by subsequent authors were referred to the genus Chalcinus (Table 1).

Museu de Ciências e Tecnologia, PUCRS, Av. Ipiranga, 6681. 90619-900 Porto Alegre, RS, Brazil. e-mail: mariacm@pucrs.br 
Table 1. Nominal species assigned to the genus Triportheus and recognized equivalent species according to the results of this study. Nominal species are cited as in the original description and are arranged alphabetically. (*) Type not examined; synonymy based on original description

\begin{tabular}{|c|c|}
\hline Nominal species & Assignment herein \\
\hline Chalceus angulatus Spix \& Agassiz 1829 & Triportheus angulatus \\
\hline Chalceus rotundatus Jardine, in Schomburgk 1841 & Triportheus rotundatus \\
\hline Chalcinus amazonensis Miranda-Ribeiro, 1941 & Triportheus auritus \\
\hline Chalcinus angulatus curtus Garman, 1890 & Triportheus curtus \\
\hline Chalcinus angulatus fuscus Garman, 1890 & Triportheus angulatus \\
\hline Chalcinus angulatus signatus Garman, 1890 & Triportheus signatus \\
\hline Chalcinus angulatus vittatus Garman, 1890 & Triportheus angulatus \\
\hline Chalcinus auritus Valenciennes, in Cuvier \& Valenciennes, 1850 & Triportheus auritus \\
\hline Chalcinus brachipomus Valenciennes, in Cuvier \& Vale nciennes, 1850 & Triportheus brachipomus \\
\hline Chalcinus brachypomus Günther, 1864 & Triportheus brachipomus \\
\hline Chalcinus cruzi Miranda-Ribeiro, $1941 *$ & Triportheus auritus \\
\hline Chalcinus culter Cope, 1872 & Triportheus culter \\
\hline Chalcinus elongatus Günther, 1864 & Triportheus auritus \\
\hline Chalcinus elongatus iquitensis Nakashima, 1941 * & Triportheus culter \\
\hline Chalcinus güntheri Garman, 1890 & Triportheus guentheri \\
\hline Chalcinus knerii Steindachner, $1876 *$ & Triportheus albus \\
\hline Chalcinus magdalenae Steindachner, 1878 & Triportheus magdalenae \\
\hline Chalcinus muellerii De Filippi, 1853 & Triportheus angulatus \\
\hline Chalcinus nematurus Kner, 1858 & Triportheus nematurus \\
\hline Chalcinus paranensis Günther, 1874 & Triportheus nematurus \\
\hline Chalcinus pictus Garman, 1890 & Triportheus pictus \\
\hline Chalcinus rotundatus iquitensis Nakashima, 1941* & Triportheus albus \\
\hline Chalcinus trifurcatus Castelnau, 1855 & Triportheus trifurcatus \\
\hline Salmo clupeoides Natterer, in Kner, 1860 & Nomen nudum \\
\hline Triportheus albus Cope, 1872 & Triportheus albus \\
\hline Triportheus flavus Cope, 1872 & Triportheus angulatus \\
\hline
\end{tabular}

The genus Triportheus was created by Cope (1872), with two new species: T. albus Cope, 1872 and T. flavus Cope, 1872. Triportheus albus was subsequently designated as the type species by Jordan (1919:363).

Eigenmann (1910:440) designated Chalcinus brachipomus as the type species of Chalcinus and considered Triportheus to be a junior synonym of that genus. Although considering the two genera to be synonyms, Myers (1940:170) suppressed Chalcinus Cuvier \& Valenciennes 1850 as a homonym, arguing that the name was preoccupied by Chalcinus Rafinesque 1815 (in Hymenoptera) and resurrected Triportheus to replace Chalcinus Valenciennes. A third generic name, Coscinoxyron, was created by Fowler (1907) to contain a single species, Chalcinus culter Cope, 1872 , but it is herein considered a junior synonym of Triportheus.

The higher level relationships of Triportheus were studied by Malabarba (1998), who proposed eight synapomorphies grouping Triportheus with Lignobrycon, and identified four derived characters to diagnose Triportheus: the very short dorsal process of cleithrum terminating just above the dorsal end of the mesocoracoid; the expansion of the upper end of the cleithrum that contacts the upper portion of the mesocoracoid into a small, medially blade-like projection; the anteroventral extension of the anterior margin of the cleithrum to lie just lateral to the ante- rior margin of the coracoid as a bifurcated anterior process; and the branching of the laterosensory canal segment in the lateral line scales.

This paper treats the species-level diversity of the genus Triportheus, with 16 species recognized of which three species described as new.

\section{Material and Methods}

Measurements were made with a digital caliper with data recorded to tenths of millimeter. Methods of measuring follow Fink \& Weitzman (1974) with some changes. Postorbital distance was measured from the posterior orbit border to the most posterior border of opercle. The distance between the dorsal and adipose fins was taken from the base of the last dorsal-fin ray to the anterior insertion of the adipose fin. Body depth at the pectoral fin was taken at the vertical slightly posterior to the pectoral-fin insertion, where the greatest body depth occurs. Lateral-line scale counts include all scales in the series including those posterior to the hypural joint. The number of branchial gill rakers refers to the count on the lower arm of the first branchial arch. The number of total vertebrae includes the four elements incorporated into the Weberian apparatus and considers the fused PU1 + PU2 as two elements. Vertebral counts were taken from radiographs. Number of scale series on caudal peduncle refers to the num- 
ber of scale rows on each side of caudal peduncle excluding middorsal and midventral series. In the counts of fin rays, lowercase roman numerals indicate unbranched rays, and Arabian numerals indicate branched rays. In counts of the branched anal-fin rays, the last two rays that usually meet basally are counted as one ray. Morphometric data of examined specimens are presented in tables associated with each species description. Entries in brackets represent data for the holotype.

In the Examined Material section of each species, data are arranged in the following sequence: country, state (or equivalent), museum catalog number, number of specimens in lot, collection locality with coordinates (when available) in parentheses. Data on collector and date collected are provided only for type materials. Data of the material collected by the Thayer Expedition were updated based on Higuchi (1996).

The following abbreviations for institutions and collections are used: AMNH, American Museum of Natural History, New York; ANSP, Academy of Natural Sciences, Philadelphia; AUM, Auburn University Museum, Auburn; BMNH, Natural History Museum, London; CAS, California Academy of Sciences, San Francisco; FMNH, Field Museum of Natural History, Chicago; INHS, Illinois Natural History Survey, Champaign; MBUCV, Museu de Biologia, Universidad Central de Venezuela, Caracas; MCP, Museu de Ciências e Tecnologia, Porto Alegre; MCZ, Museum of Comparative Zoology, Cambridge; MNHN, Muséum National d'Histoire Naturelle, Paris; MNRJ, Museu Nacional, Rio de Janeiro; MUSM, Museo de Historia Natural, Universidade Nacional Mayor de San Marcos, Lima; MZUSP, Museu de Zoologia da Universidade de São Paulo, São Paulo; MZUT, Museo Regionale di Scienze Naturali, Torino; NMW, Naturhistorisches Museum Wien, Vienna; NRM, Naturhistoriska Riksmuseet, Stockholm; UFAC, Universidade Federal do Acre, Rio Branco; UMMZ, University of Michigan Museum of Zoology, Ann Arbor; UNELLEZ, Universidad Nacional Experimental de los Llanos Occidentales Ezequiel Zamora; and USNM, National Museum of Natural History, Smithsonian Institution, Washington D.C.

\section{Triportheus Cope, 1872}

Chalcinus Valenciennes in Cuvier \& Valenciennes, 1850:258 [Published as 1849]. Type species: Chalcinus brachipomus Valenciennes, 1850 , by subsequent designation of Eigenmann, 1910:440. Preoccupied by Chalcinus Rafinesque, 1815, in Hymenoptera.

Triportheus Cope, 1872:263. Type species: Triportheus albus Cope, 1872 by subsequent designation of Jordan, 1919:363.

Coscinoxyron Fowler, 1907:450. Type species: Chalcinus culter Cope, 1872:265 by original designation and monotypy.

Diagnosis. Triportheus is diagnosed from other genera of the Characidae by the derived presence of: (1) a very short dorsal process of cleithrum terminating just above the dorsal limit of the mesocoracoid (versus process of cleithrum distinctly extending beyond the upper margin of the mesocoracoid); (2) the expansion of the upper end of the cleithrum which meets the upper portion of the mesocoracoid as a small median blade-like projection (versus expansion of cleithrum absent); (3) the expansion of anterior margin of the cleithrum anteroventrally to lie just lateral to the anterior margin of the coracoid and forming a bifurcated anterior process (versus anterior process of the cleithrum not bifurcated); and (4) the branching of lateral-line scales one to three times (versus canal tubes single and unbranched). An additional character distinguishing Triportheus is the low number of scales (1-2) in the transverse series from the pelvic-fin insertion to the lateral line.

Distribution. Río Magdalena, río Orinoco, Essequibo River, rio Amazonas, rio Tocantins, rio São Francisco, rio Parnaíba, río Paraguay, and lower rio Paraná basins.

Remarks. Myers (1940:170) proposed the suppression of Chalcinus Valenciennes (1850) which was preoccupied by Chalcinus Rafinesque (1815) in Hymenoptera. Eschmeyer (1998:1886) suggested Chalcinus Valenciennes was not preoccupied by Chalcinus Rafinesque (1815), since it was "apparently an unjustified emendation of Chalcis Fabricius (1787) in Hymenoptera". However, according to the ICZN (1999:9, article 10.6), a name once available remains so, irrespective of its lack of validity as an unjustified emendation, and (p. 42, article 33.2.3), it remains available with its own author and date and is a junior objective synonym of the name in its original spelling. Thus, Chalcinus Valenciennes is a junior homonym of Chalcinus Rafinesque, regardless of whether it was a justified emendation for Chalcis Fabricius.

\section{Keys to the species of Triportheus}

The genus Triportheus is readily distinguished from other characids by its body shape, midventral keel and large pectoral fins. However, it demonstrates a limited degree of intrageneric morphological variation. This fact associated to high species endemism (most of species are confined to one of the major South American drainage basins) would limit the usefulness of an all-inclusive species key. In order to facilitate identification of the species, regional keys, each of which includes a drainage system or a set of drainages, are presented. Only three species, $T$. auritus, T. brachipomus, and T. albus, are present in more than one drainage. Triportheus magdalenae (Steindachner, 1878) is the only Triportheus species in the río Magdalenae basin, and the only known occurrence of the genus to the west of the Andean Cordilleras. Table 2 displays the known distribution of the Triportheus species in the major river basins and drainages in South America. As some species distributions are based on very old and/or too limited samples, they will probably change by reporting new occurrences or species provided by further collecting efforts. 
Table 2. Occurrence of species of Triportheus in the major river drainages of South America.

\begin{tabular}{|c|c|c|c|c|c|c|c|c|}
\hline & 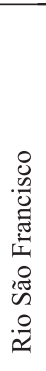 & 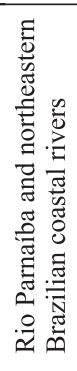 & 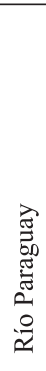 & 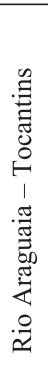 & 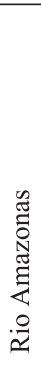 & 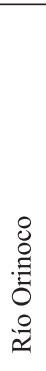 & 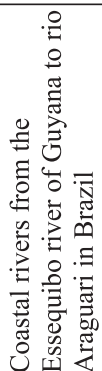 & $\begin{array}{l}\frac{\pi}{0} \\
\frac{\pi}{\pi} \\
\frac{\pi}{00} \\
\sum_{0}^{\pi} \\
0\end{array}$ \\
\hline T. albus & - & - & - & $\mathrm{X}$ & $\mathrm{X}$ & - & - & - \\
\hline T. angulatus & - & - & - & - & $\mathrm{X}$ & - & - & - \\
\hline T. auritus & - & - & - & $\mathrm{X}$ & $\mathrm{X}$ & $\mathrm{X}$ & $\mathrm{X}$ & - \\
\hline T. brachipomus & - & - & - & - & - & $\mathrm{X}$ & $\mathrm{X}$ & - \\
\hline T. culter & - & - & - & - & $\mathrm{X}$ & - & - & - \\
\hline T. curtus & - & - & - & - & $\mathrm{X}$ & - & - & - \\
\hline T. guentheri & $\mathrm{X}$ & - & - & - & - & - & - & - \\
\hline T. magdalenae & - & - & - & - & - & - & - & $\mathrm{X}$ \\
\hline T. nematurus & - & - & $X$ & - & - & - & - & - \\
\hline T. orinocensis & - & - & - & - & - & $\mathrm{X}$ & - & - \\
\hline T. pantanensis & - & - & $\mathrm{X}$ & - & - & - & - & - \\
\hline T. pictus & - & - & - & - & $\mathrm{X}$ & - & - & - \\
\hline T. rotundatus & - & - & - & - & $\mathrm{X}$ & - & - & - \\
\hline T. signatus & - & $\mathrm{X}$ & - & - & - & - & - & - \\
\hline T. trifurcatus & - & - & - & $\mathrm{X}$ & - & - & - & - \\
\hline T. venezuelensis & & & & & & $\mathrm{X}$ & & \\
\hline
\end{tabular}

\section{Key to the species of Triportheus in the Amazon basin}

1. Body deep; depth at dorsal-fin origin usually more than $30 \%$ of SL; 2 scale rows between pectoral-fin insertion and ventral keel ... 2

1'. Body elongated; depth at dorsal-fin origin usually less than $30 \%$ of SL; 1 large scale row between pectoral-fin insertion and ventral keel

2. Branched anal-fin rays, 20-21 ............................. T. pictus

3. Lateral line scales, 28-37; at least 6 scale rows between lateral line and dorsal fin origin; branched anal fin rays, 24-28; gill rakers on lower limb of first gill arch, 24-37

3'. Lateral line scales, 30-33; less than 6 scale rows between lateral line and dorsal fin origin; branched anal fin rays, 25-31; gill rakers on lower limb of first gill arch, 23-28

T. curtus

4. Lateral line scales, 28-34; gill rakers on lower limb of first gill arch, 24-30 T. rotundatus

4'. Lateral line scales, 34-37; gill rakers on lower limb of first gill arch, 29-37 T. angulatus

5. Lateral line scales, 32-35 T. albus

5'. Lateral line scales equal or more than 40 .. 6

6. Gill rakers on lower limb of first gill arch, 22-28; lateral line scales, 40-46; branched anal-fin rays, 24-28 T. auritus

6. Gill rakers on lower limb of first gill arch, 53-83; lateral line scales, 43-47; branched anal-fin rays, 28-30 T. culter
Key to the species of Triportheus in the ParanáParaguay basins

1. Gill rakers on lower limb of first gill arch, 38-48; lateral line scales, 33-37; branched anal-fin rays, 26-31; predorsal distance, $56.1 \%-61.6 \%$ of SL (mean 58.8\%); depth at dorsal fin origin, $31.9 \%-36.9 \%$ of SL (mean $33.6 \%$ ) T. nematurus

1'. Gill rakers on lower limb of first gill arch, 26-33; lateral line scales, 28-37; branched anal-fin rays, 25-30; predorsal distance, 59.3\%-64.6\% of SL (mean 61.8\%); depth at dorsal fin origin, $34.6 \%-42.5 \%$ of SL (mean $38.6 \%$ ) T. pantanensis

Key to the species of Triportheus in the rio Araguaia Tocantins basins

1. Body elongated; 1 scale row between pectoral-fin insertion and ventral keel; depth at dorsal-fin origin usually less than $30 \% \mathrm{SL}$

1'. Body deep; 2 scale rows between pectoral-fin insertion and ventral keel; depth at dorsal fin origin, $27.0 \%-36.2 \%$ of SL (mean $31.2 \%$ ); lateral line scales, 32-35; gill rakers on lower limb of first gill arch, 4047; scale rows between lateral line and dorsal-fin origin, 5-6. T. trifurcatus

2. Lateral line scales, 40-46; gill rakers on lower limb of first gill arch, 22-28 T. auritus

2'. Lateral line scales, 32-35; gill rakers on lower limb of first gill arch, 30-39 T. albus

Key to the species of Triportheus in the rio São Francisco and Parnaíba basins and northeastern Brazilian coastal drainages

1. Lateral line scales, 34-37; gill rakers on lower limb of first gill arch, 35-44; scale rows between lateral line and dorsalfin origin, 6; depth at dorsal-fin origin, 27.6\%-35.0\% of SL (mean 30.7\%)

T. signatus

1'. Lateral line scales, 30-33; gill rakers on lower limb of first gill arch, 52-57; scale rows between lateral line and dorsal fin origin, 5; depth at dorsal fin origin, 28.2\%-37.0\% of SL (mean 33.4\%) T. guentheri

Key to the species of Triportheus in the río Orinoco and coastal rivers from the Essequibo river in Guyana to rio Araguari in Brazil

1. Body elongate; 1 scale row between pectoral-fin insertion and ventral keel; depth at dorsal-fin origin usually less than $30 \%$ SL

1'. Body deep; 2 scale rows between pectoral-fin insertion and ventral keel; depth at dorsal-fin origin usually more than $30 \%$ SL 
2. Lateral line scales, 40-46; gill rakers on lower limb of first gill arch, 22-28; branched anal-fin rays, 24-28; scale rows between lateral line and dorsal-fin origin, 6 T. auritus

2'. Lateral line scales, 32-38; gill rakers on lower limb of first gill arch, 30-40; branched anal-fin rays, 22-27 T. brachipomus

3. Branched anal fin rays, 28-32; lateral-lines scales, 34-39; gill rakers on lower limb of first gill arch, 24-28; depth at dorsalfin origin, $28.7 .6 \%-37.1 \%$ of SL (mean $33.4 \%$ ); scale rows between lateral line and dorsal-fin origin, 7 T. orinocensis

3'. Branched anal fin rays, 24-27; lateral-lines scales, 33-36; gill rakers on lower limb of first gill arch, 27-33; depth at dorsal-fin origin, $26.7 \%-37.6 \%$ of SL (mean $32.9 \%$ ); scale rows between lateral line and dorsal-fin origin 5-6 T. venezuelensis

\section{Triportheus angulatus (Spix \& Agassiz, 1829)} Fig. 1

Chalceus angulatus Spix \& Agassiz, 1829:67-68, fig. 34 (description; inexact type-locality: "in Brasiliae aequinoctialis fluviis").

Chalcinus angulatus. Valenciennes, in Cuvier \& Valenciennes, 1850:263-4 (discussion).

Chalcinus angulatus vittatus Garman, 1890:4 (description, type-locality: "José Fernandez, Villa Bella, Porto do Moz, and Santarem").

Chalcinus angulatus fuscus Garman, 1890:4 (description, type-locality: "Villa Bella and Lake Hyanuary").

Chalcinus müllerii De Filippi, 1853:165-166 (type-locality: Hab. rio Napo).

Triportheus flavus Cope, 1872:264 (description, río Ampyacu, Peru).

Chalcinus angulatus angulatus. Bertoni, 1939:56

Triportheus angulatus. Fowler, 1941:194

Triportheus angulatus angulatus. Fowler, 1950:355-356

Diagnosis. A deep bodied Triportheus species reaching 163 mm of SL (depth at dorsal-fin origin, 29.0-36.7 \% SL; depth at pectoral-fin insertion, 32.9-39.8\% SL). The presence of 2 longitudinal scale rows between the pectoral-fin insertion and ventral keel distinguish this species from the Triportheus species with elongate bodies that have 1 scale row between the pectoral-fin insertion and the ventral keel. Triportheus angulatus differs from the other deep bodied congeners in the combination of lateral line scale counts $(34-37$, mean $=$ $35.7, \mathrm{n}=62)$; the count of gill rakers on the lower limb of first arch $(29-37$, mean $=32.3, \mathrm{n}=68)$; the number of branched anal-fin rays $(26-31$, mean $=28.8, n=67)$; and the presence of longitudinal dark stripes on the lateral surface of the body.

Description. Morphometric data of Triportheus angulatus presented in Table 3. Body deep and compressed laterally.
Greatest body depth located slightly posterior to vertical through insertion of pectoral fin. Dorsal profile of head straight or slightly convex from snout to rear of head. Dorsal profile of body gently curved from rear of head to dorsal-fin origin; posteroventrally slanted from dorsal-fin origin to caudal peduncle; straight along caudal peduncle. Dorsal portion of body slightly keeled.

Ventral profile of head straight from tip of lower lip to anteroventral margin of dentary; straight from that point to isthmus. Ventral profile of body strongly arched from isthmus to pelvic-fin insertion; nearly convex from pelvic-fin insertion to anal-fin insertion; posterodorsally slanted along anal-fin base; slightly concave along caudal peduncle. Prepelvic region greatly expanded vertically and compressed, with well defined keel.

Mouth slightly upturned, with lower jaw longer than upper jaw. Posterior margin of opercle reaching vertical through pectoral-fin insertion. Nostrils of each side close together; anterior opening circular; posterior elongate.

Gill rakers thin and close together, length equivalent to half of branchial filament length; gill rakers 29-37 [33] $($ mean = $32.3 ; n=68)$.

Teeth on premaxilla in 3 rows; teeth of inner row largest. Five or 6 tricuspidate teeth on outer row; outer row teeth arranged along external margin of premaxilla and visible externally. Medial premaxillary tooth row with 2 or 3 tricuspidate teeth. Six or 7 multicuspidate teeth on inner row of premaxilla. Teeth on maxilla 1-3, much smaller than those on premaxilla and tricuspidate. Teeth on lower jaw in 2 rows. Outer row with 4-6 larger teeth, with 5-7 cusps, and decreasing in size posteriorly. Inner row formed by a small conical tooth, slightly curved posteriorly.

Scales cycloid, thin, and large. Lateral line distinctly decurved ventrally, completely pored from supracleithrum to base of caudal fin rays. Thirty-four to 37 [36] scales along lateral line $($ mean $=35.7 ; n=62) ; 5-6$ (usually 6) [6] scale series above lateral line. Two scale rows below lateral line. Two scale rows between pectoral-fin insertion and midventral keel. Five scale series on caudal peduncle. Scales along mid-dorsal line very irregularly arranged, with 6-13 [13] scales from supraoccipital process to dorsal-fin origin.

Dorsal-fin rays ii,9; anal-fin rays iii,26-31 [28] (mean = 28; $\mathrm{n}=67$ ); pectoral-fin rays i,11-13 [11]; pelvic fin rays i,6. Dorsal-fin margin straight, situated on posterior half of body; base of last dorsal-fin ray situated slightly anterior to, or at, vertical through anal-fin origin; second unbranched and first branched ray longest; following rays slightly decreasing in length. Pectoral fin pointed, tip falling within region from middle to tip of pelvic fin. Anal fin margin straight, first branched anal-fin ray longest; following rays gradually decreasing in length. Margin of caudal fin truncate; median rays extend slightly beyond margin of remainder of fin. Scales present over anterior one third of fin.

Total vertebrae 38 .

Coloration in alcohol. Overall ground color yellowish and overlain with guanine. Snout and dorsal region of head 


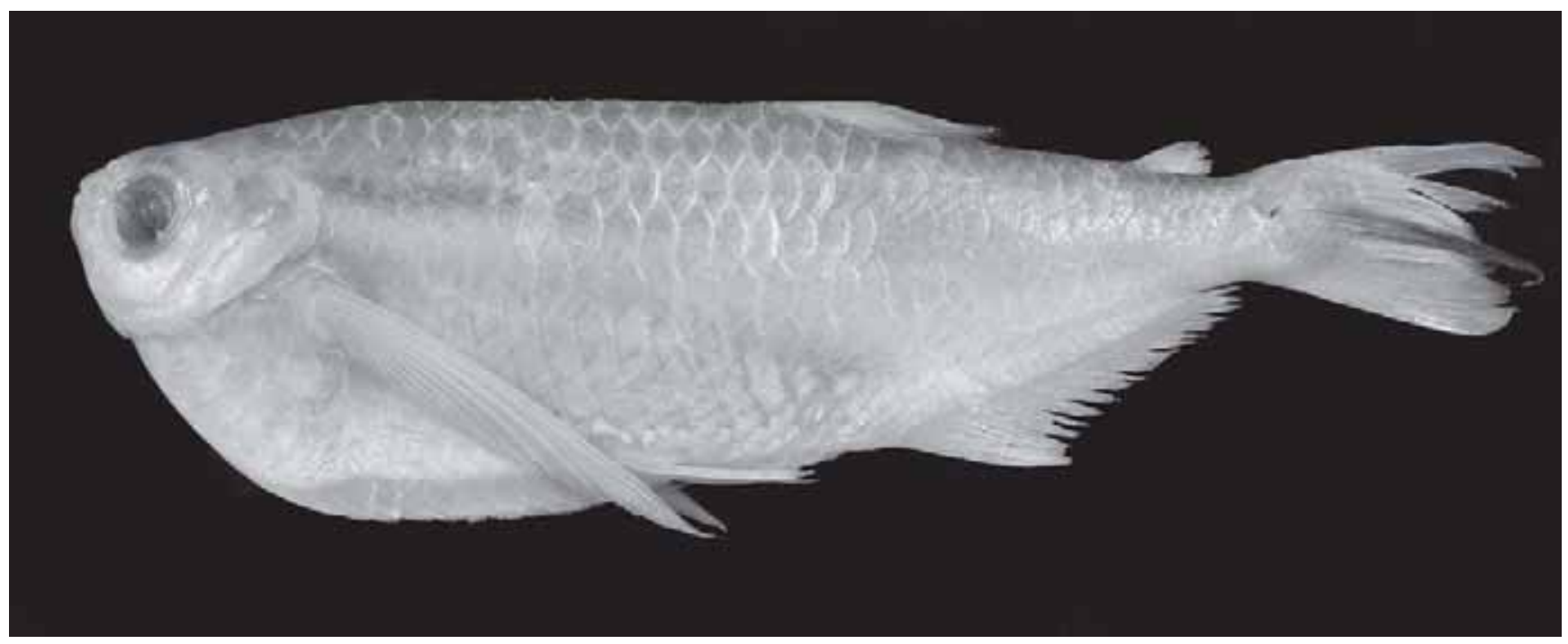

Fig. 1. Triportheus angulatus, neotype, MCP 29943, 130.5 mm SL, Brazil, Amazonas, rio Solimões, ilha do Prego.

dark. Some scattered dark chromatophores present on opercle and infraorbitals 5 and 6 . Body darker dorsally and on analfin base and peduncle. Five or 6 longitudinal brown stripes present on dorsolateral portion of body. Dark chromatophores distributed all over fins. Dorsal fin rays outlined by dark chromatophores. Scattered chromatophores distributed over all of pectoral fin; with more intense pigmentation on first unbranched ray and along fin margin. Some dark chromatophores outlining anal-fin rays. Middle caudal-fin rays very dark.

Distribution. Amazon and Essequibo river basins (Fig. 2).

Remarks about type-locality and type-specimens. Triportheus angulatus is the first described species of the genus and its description was based on specimens collected by the Spix and Martius expedition in Brazil between 1817 and 1820. During this period they first traveled north from Rio de Janeiro, crossing tributaries of the upper rio Paraná, rio São Francisco, and several smaller Atlantic drainages prior to their arrival in Belém. From Belém they traveled by boat along a portion of the rio Tocantins and through the rio Amazonas, to the rio Negro and rio Solimões as far west as Benjamin Constant (Papavero, 1971:65-69 and map). Thus, the collecting locality of Chalceus angulatus could be in the São Francisco, Tocantins, or Amazonas basins. Spix \& Agassiz (1829:67) cite the collecting locality of the material only as "in Brasiliae aequinoctialis fluviis".

The specimens collected by Spix (except those subsequently donated to Agassiz) were housed in Zoologische Staatssammlung München (ZSM) until its destruction during a British bombing raid on the night of 24-25 April 1944 (Kottelat, 1988: 69). Kottelat (1988:84) presents a list of Spix \& Agassiz's types still extant in the ZSM, MHNN (Musée d'Histoire Naturelle de Neuchâtel) and MHNG (Musée d'Histoire Naturelle de Geneve). No Chalceus angulatus specimens are included in this list and the types of the species were apparently lost or destroyed. A neotype (MCP 29943) is herein designated for Triportheus angulatus, as a specimen collected in the rio Amazonas basin (Solimões drainage, Amazonas state, Brazil). This is the species that best fits the original description and drawing provided by Agassiz, in terms of general body shape, dorsal-fin position, pectoral-fin length, and anal-fin ray count.

The type locality of Chalcinus muellerii is listed as "Hab. in Rio Napo" in the original description (Di Filippi, 1853), but the type's label cites the locality as "Rio Negro Brasile".

Type-material examined. Triportheus angulatus: Neotype by present designation, MCP 29943, $130.59 \mathrm{~mm}$ SL, Brazil, Amazonas, rio Solimões, ilha do Prego, opposite to Alvarães, W. Crampton, 15 Jan 2001 ( $3^{\circ} 10^{\prime} 37^{\prime \prime S}$, $\left.64^{\circ} 48^{\prime} 1^{\prime \prime} \mathrm{W}\right)$.

Chalcinus angulatus vittatus: syntypes, Brazil, Amazonas: MCZ 21183 (10), Villa Bella [rio Amazonas at Parintins and environs], L. Agassiz, 2 Sep 1865 [02³8'S, 56 45' W]; MCZ 21224 (33,) José Fernandes lake [presumably near Manaus], J. M. S. Coutinho, Dec 1865. Pará: MCZ 21216 (3), Porto do Moz [rio Xingu at Porto de Mos], Sep 1865, Vinhas [ $1^{\circ} 45^{\prime} \mathrm{S}$, 41 ${ }^{\circ}$ 4'W]; MCZ 21175 (22, MCZ21201 + MCZ21202 + MCZ 21239 +MCZ 21240), near Santarém, 1873, C. Bourget [02 $43^{\prime}$ 'S, 54 $\left.07^{\circ} \mathrm{W}\right]$.

Chalcinus angulatus fuscus: syntypes, Brazil, Amazonas: MCZ 21270 (8 of 18), lago Hyanuary, 29 Sep 1865, L. Agassiz [paraná do Janauari, $03^{\circ} 12^{\prime}$ 'S, 6005'W]; MCZ 21186 (10, MCZ $21190+$ MCZ 21191), Villa Bella [rio Amazonas at Parintins and environs, $\left.2^{\circ} 38^{\prime} \mathrm{S}, 56^{\circ} 45^{\prime} \mathrm{W}\right] 2$ Sep 1865.

Chalcinus muellerii: holotype, MZUT 92641, Rio Napo [Peru], M. Osculati.

Triportheus flavus: lectotype, ANSP 8077, Peru, Ampyacu River, J. Hauxwell. Paralectotypes, ANSP 8074 (2), ANSP 8078-8080, same data as lectotype. 
Table 3. Morphometrics of Triportheus angulatus. Ranges are given separately for the neotype, syntypes of Chalcinus angulatus fuscus (28) Chalcinus angulatus vittatus (32), holotype of Chalcinus muellerii, lectotype of Triportheus flavus and 85 non-type specimens: NRM 30504 (1); NRM 30502 (1 of 4) NRM 30488 (1), NRM 30505 (3), USNM 295166 (8 of 9), USNM 280510 (2), FMNH 103035 (3), FMNH 103042 (2), FMNH 103036 (2), UMMZ 205124 (5 of 14), AUM 23484 (21 of 57), AUM 23566 (4 of 9), INHS 72382 (5 of 8), FMNH 56503 (1 of 2), AUM 23520 (2 of 3), UMMZ 204881 (11), USNM 179513 (3), UMMZ 56780 (10 of 12)

\begin{tabular}{|c|c|c|c|c|c|c|c|}
\hline \multirow{2}{*}{ Character } & \multicolumn{5}{|c|}{ Types } & \multicolumn{2}{|c|}{ Non-types } \\
\hline & Neotype & C. vittatus & C. fuscus & C. muellerii & T. flavus & Range & Mean \\
\hline Standard length (mm) & 130.5 & $42.8-159.0$ & $80.8-139.7$ & 128.33 & 126.73 & $62.7-163.0$ & 105.2 \\
\hline \multicolumn{8}{|c|}{ Percents of standard length } \\
\hline Bony head length & 23.1 & $23.4-27.5$ & $22.7-25.3$ & 22.6 & 24.8 & $22.0-27.5$ & 25.0 \\
\hline Snout to anal-fin origin & 71.9 & $68.8-75.3$ & $53.9-72.8$ & 70.7 & 68.0 & $68.5-76.3$ & 72.6 \\
\hline Snout to dorsal-fin origin & 58.4 & $39.9-63.4$ & $56.6-62.5$ & 58.6 & 60.7 & $46.8-63.4$ & 59.5 \\
\hline Snout to pelvic-fin origin & 51.5 & $49.0-70.8$ & $46.8-70.4$ & 50.2 & 49.3 & $49.7-58.1$ & 53.5 \\
\hline Anal-fin base length & 26.0 & $21.0-29.0$ & $21.3-27.2$ & 26.8 & 23.7 & $22.2-28.6$ & 25.7 \\
\hline Caudal peduncle length & 7.2 & $7.1-11.0$ & $7.6-11.5$ & 8.02 & 9.0 & $5.1-8.6$ & 6.8 \\
\hline Caudal peduncle depth & 8.3 & $7.6-10.5$ & $7.8-9.5$ & 8.5 & 7.9 & $7.6-10.2$ & 8.8 \\
\hline Depth at dorsal-fin origin & 29.8 & $25.1-34.0$ & $26.3-33.1$ & 28.5 & 30.3 & $29.0-36.7$ & 33.1 \\
\hline Depth at pectoral fin & 34.1 & $26.2-36.3$ & $31.1-35.7$ & 32.4 & 32.5 & $32.9-39.8$ & 36.0 \\
\hline Dorsal-fin height & 17.7 & $14.6-23.8$ & $17.8-20.9$ & 28.5 & 16.7 & $16.0-21.5$ & 19.2 \\
\hline Pelvic-fin length & 15.8 & $9.3-15.6$ & $11.6-15.6$ & 13.9 & 9.8 & $10.3-17.3$ & 14.5 \\
\hline Pectoral-fin length & 38.6 & $29.5-40.0$ & $34.1-41.1$ & 38.7 & 37.9 & $32.6-41.3$ & 37.9 \\
\hline \multicolumn{8}{|c|}{ Percents of head length } \\
\hline Snout length & 21.2 & $18.7-25.7$ & $20.1-30.7$ & 20.4 & 22.1 & $17.1-23.8$ & 20.7 \\
\hline Upper jaw length & 22.0 & $20.9-27.9$ & $16.0-28.5$ & 23.9 & 19.5 & $20.7-27.7$ & 23.7 \\
\hline Horizontal eye diameter & 27.7 & $24.4-33.6$ & $26.1-33.6$ & 26.8 & 30.1 & $23.3-31.6$ & 27.6 \\
\hline Least interorbital width & 31.4 & $26.1-36.7$ & $30.7-37.1$ & 33.2 & 31.6 & $28.1-36.2$ & 32.0 \\
\hline
\end{tabular}

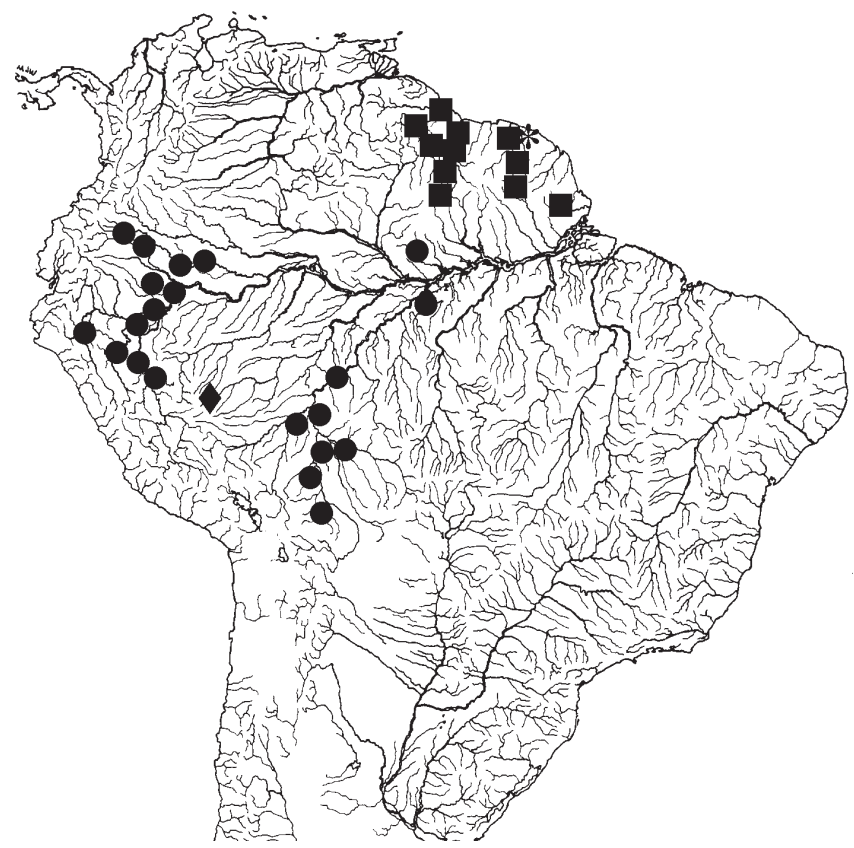

Fig. 2. Map of central and northern South America showing geographic distribution of Triportheus angulatus (circles; diamond $=$ neotype locality) and $T$. brachipomus (squares; asterisk $=$ lectotype locality) (some symbols represent more than one locality or lot of specimens).

Non-type material. Bolivia: Beni: UMMZ 205100 (4), arroyo Grande at mouth, $1 \mathrm{~km} \mathrm{~N}$ of Guayaramerin (10 $\left.48^{\prime} \mathrm{S}, 65^{\circ} 24^{\prime} \mathrm{W}\right)$; UMMZ 205124 (14), río Mamoré near head of Isla Nicolas Suarez, between Guayaramerin and Guajara Mirim $\left(10^{\circ} 49^{\prime} \mathrm{S}, 65^{\circ} 21^{\prime} \mathrm{W}\right)$;
AUM 23484 (57), lago Tumi Chucua, 26 km SSW Riberalta (11 7' S, 661'W); AUM 23566 (9), Lago Tumi Chucua, 26 km SSW Riberalta (11 $\left.{ }^{\circ} 7^{\prime} \mathrm{S}, 66^{\circ} 11^{\prime} \mathrm{W}\right)$; FMNH 56503 (2), San Joaquin; AUM 23520 (3), río Beni 25 km SW Riberalta (11 ${ }^{\circ} 12^{\prime}$ S, 66 69' W); USNM 303109 ( 2 of 4), Ballivia Prov., río Curiraba at $10 \mathrm{~km} \mathrm{NE} \mathrm{El} \mathrm{Porvenir}$ Biological Station, 40 air km E San Borja (145' $\left.\mathrm{S}, 66^{\circ} 17^{\prime} \mathrm{W}\right)$; UMMZ 204881 (11), río Baures $2 \mathrm{~km}$ above mouth (at second sand riffle) $\left(12^{\circ} 32^{\prime} \mathrm{S}, 6^{\circ} 19^{\prime} \mathrm{W}\right)$. Brazil: Amazonas: INHS 72382 (8), lago Terra Preta, about $8 \mathrm{~km} \mathrm{SW}$ Manaus $\left(3^{\circ} 12^{\prime} \mathrm{S}, 60^{\circ} 1^{\prime} \mathrm{W}\right)$; USNM 179513 (3), rio Urubu 25 miles from Itacoatiara ( $3^{\circ} 0^{\prime} \mathrm{S}$, $\left.58^{\circ} 25^{\prime} \mathrm{W}\right)$; FMNH 56505 (1), Manaus (312'S, 60¹'W). Pará: FMNH 56502 (3 of 4), Santarém ( $\left.0^{\circ} 57^{\prime} \mathrm{S}, 46^{\circ} 59^{\prime} \mathrm{W}\right)$; USNM 307111(1), lago Murumuru, plantação de juta, Janauacá, $\left(3^{\circ} 25^{\prime} \mathrm{S}\right.$, $60^{\circ} 16^{\prime} \mathrm{W}$ ); USNM 30776 (3 of 4), paraná of Ilha de Marchantaria (44'S, 597'W). Rondônia: UMMZ 56780 (12), Porto Velho, rio Madeira, Amazonas drainage ( $\left.8^{\circ} 46^{\prime} \mathrm{S}, 63^{\circ} 54^{\prime} \mathrm{W}\right)$. Ecuador: Napo: FMNH 103035 (3), río Yasuni, 1-2 km downstream from confluence with río Jatuncocha $\left(0^{\circ} 59^{\prime} \mathrm{S}, 7^{\circ} 25^{\prime} \mathrm{W}\right)$; FMNH 103036 (2), río Yasuni, laguna Jatuncocha, all parts $\left(1^{\circ} 0^{\prime} \mathrm{S}, 75^{\circ} 26^{\prime} \mathrm{W}\right)$. FMNH 103042 (2), río Aguarico about $1 \mathrm{~km}$ upstream from Destacamento Lagartococha (0³8'S, 75² $\left.18^{\prime} \mathrm{W}\right)$. Guyana: ANSP 178468 (1), Essequibo River, extensive sandbar $2 \mathrm{~km}$ upstream from Paddle Rock campsite $\left(04^{\circ} 42^{\prime} \mathrm{N}, 58^{\circ} 42^{\prime} \mathrm{W}\right)$. Peru: Loreto: INHS 43221 (1), Puerto Iquitos; NRM 28635 10, río Putumayo drainage: downstream of El Estrecho, Cedros Cano ( $\left.2^{\circ} 28^{\prime} \mathrm{S}, 72^{\circ} 41^{\prime} \mathrm{W}\right)$; NRM 30502 (1 of 4), río Putumayo right bank, El Estrecho ( $2^{\circ} 28^{\prime} \mathrm{S}$, $\left.72^{\circ} 41^{\prime} \mathrm{W}\right)$; USNM 280510 (2), District Coronel Portillo, Yarinacocha, side Cano ( $8^{\circ} 16^{\prime}$ 'S, $\left.74^{\circ} 36^{\prime} \mathrm{W}\right)$; NRM 30504 (1), río Samiria drainage: Atún Cano, gramalote ( $\left.4^{\circ} 41^{\prime} \mathrm{S}, 74^{\circ} 18^{\prime} \mathrm{W}\right)$; NRM 30488 (1), río Itaya; NRM 30505 (3), río Samiria drainage (441’S, 74¹8'W). Madre de Dios: USNM 295166 (9), Parque Nacional Manu, Pakitza and vicinity (12 $15^{\prime}$ 'S, 70 $\left.54^{\prime} \mathrm{W}\right)$; NRM 13449 (2), caño between Yarinacocha and Cashibococha, $8 \mathrm{~km} \mathrm{NW}$ of Puerto Callao ( $8^{\circ} 18^{\prime}$ 'S, 7436' W). 


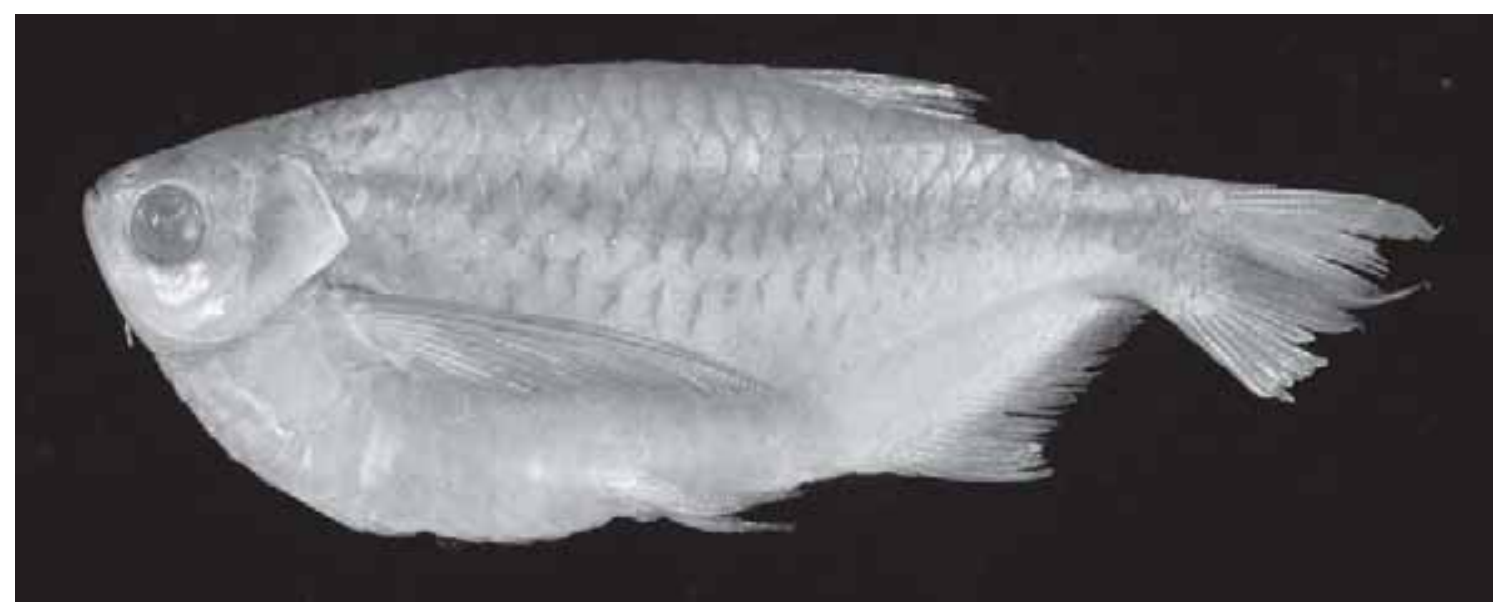

Fig. 3. Triportheus rotundatus, neotype, MCP 34863, 97.83 mm SL, Brazil, Acre, rio Purus drainage, lago Amapá.

Triportheus rotundatus (Jardine in Schomburgk, 1841) Fig. 3

Chalceus rotundatus Jardine in Schomburgk, 1841:209-10 (drawing; type-locality: river Padauiri). Günther, 1864:341 (as synonym of Chalcinus brachypomus). Eigenmann \& Eigenmann, 1891:56 (as synonym of Chalcinus angulatus). Eigenmann, 1910:440 (as synonym of Chalcinus güntheri).

Chalcinus rotundatus. Fowler, 1907:450.

Triportheus rotundatus. Fowler, 1945:154 (listed; Peru (Iquitos), Guayana, Brazil).

Diagnosis. A deep bodied Triportheus species that reaches $178 \mathrm{~mm}$ of SL (depth at dorsal-fin origin, 29.7-40.1\% SL; depth at pectoral-fin insertion, 34.0-39.9\% SL). Triportheus rotundatus can be distinguished from other Triportheus species by the combination of the presence of 2 longitudinal scale rows between the pectoral-fin insertion and ventral keel; the number of gill rakers on the lower limb of first arch $(24-32$, mean $=27.6, n=37)$; the number of branched anal-fin rays $(25-29$, mean $=27.1, \mathrm{n}=37)$, and number of lateral line scales $(28-35$, mean $=32.3, n=35)$; the presence of longitudinal dark stripes on the lateral surface of the body; and the median caudal rays developed into a slightly projecting extension.

Description. Morphometric data of Triportheus rotundatus presented in Table 4. Body deep and compressed laterally. Greatest body depth located slightly posterior to vertical through insertion of pectoral fin. Dorsal profile of head straight from snout to rear of head. Dorsal profile of body gently curved from rear of head to dorsal-fin origin; posteroventrally slanted from dorsal-fin origin to caudal peduncle; slightly curved along caudal peduncle.

Ventral profile of head straight from tip of lower lip to anteroventral margin of dentary; straight from that point to isthmus. Ventral profile of body arched from isthmus to pelvic-fin insertion; nearly convex from pelvic-fin insertion to anal-fin origin; posterodorsally slanted along anal-fin base; slightly concave along caudal peduncle. Prepelvic region very expanded and compressed, with well defined keel.

Head blunted in profile; posterior margin of opercle not reaching pectoral-fin insertion. Mouth terminal; slightly upturned. Nostrils of each side close together; anterior opening circular; posterior elongate.

Gill rakers thin and close together; length equivalent to one-half of branchial filament length; gill rakers on lower limb of first arch 24-32 [28] (mean = 27.6, $\mathrm{n}=37)$.

Teeth on premaxilla in 3 rows; teeth of inner row largest. Four or 5 tricuspidate teeth in outer row; outer row teeth positioned along external margin of mouth and can be seen externally. Middle tooth row with 3 tricuspidate teeth; 6 multicuspidate teeth on inner tooth row. Teeth on maxilla 2 , teeth smaller than those on premaxilla and flattened. Teeth on lower jaw in 2 rows, outer row with 5 large anterior teeth, and 6 smaller posterior teeth. Inner row formed of single conical, symphyseal tooth.

Scales cycloid, thin, and large. Lateral line distinctly decurved ventrally, completely pored from supracleithrum to base of caudal-fin rays. Twenty-eight to 34 [30] $($ mean $=32.3$, $\mathrm{n}=35$ ) scales along lateral line; 6 scale series above lateral line; 2-3 [2] scale rows below lateral line. Two scale rows between pectoral-fin insertion and midventral keel; 4-5 scale series on caudal peduncle. Scales along mid-dorsal line irregularly arranged, 6-13 (mean $=9.3, \mathrm{n}=30$ ) between tip of supraoccipital and dorsal-fin origin.

Dorsal-fin rays ii,9; anal-fin rays iii, 25-29 [27] $($ mean $=$ 27.1, $\mathrm{n}=37$ ); pectoral-fin rays i, 11-13 [11] $($ mean $=11.5, \mathrm{n}=$ 36); pelvic fin rays i,6. Dorsal-fin margin straight, situated on posterior one half of body; last dorsal-fin ray located at vertical through base of third or fourth branched anal-fin ray; first branched ray longest; following rays slightly decreasing in length. Pectoral fin pointed, tip extending to region falling between middle and tip of pelvic fin. Anal fin margin straight, first branched anal-fin ray longest; following rays gently decreasing in length. Margin of caudal fin truncate; median rays extend slightly beyond margin of remainder of fin. Scales cover basal one-third of caudal fin.

Total vertebrae 37 . 


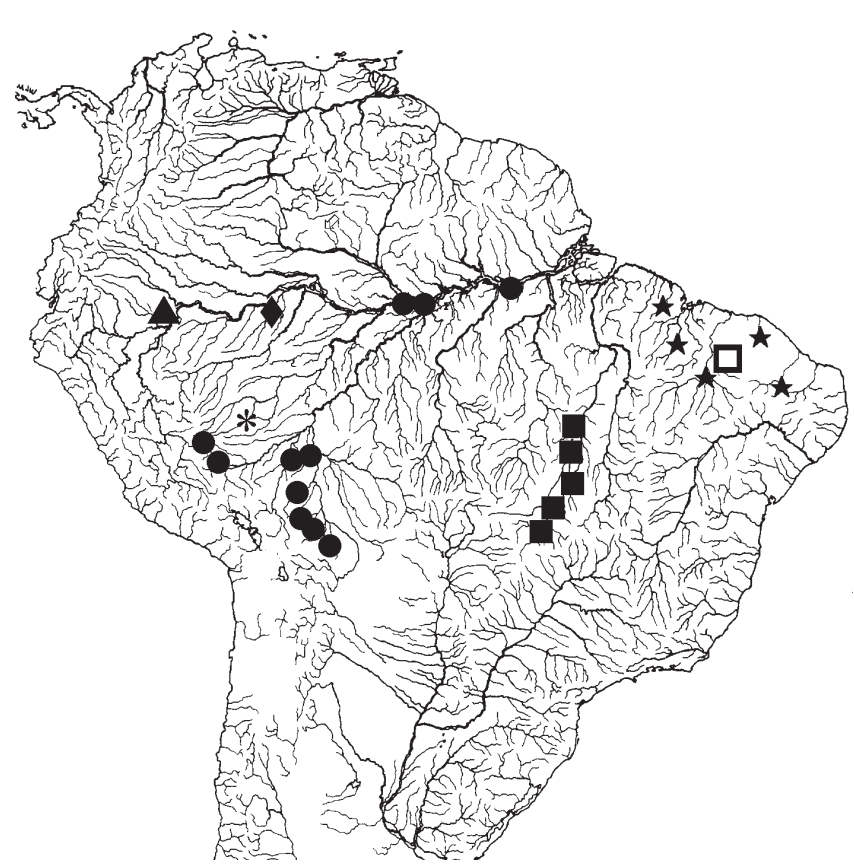

Fig. 4. Map of central and northern South America showing geographic distribution of Triportheus rotundatus (circles; asterisk = neotype locality), T. trifurcatus (black squares), $T$. pictus (triangle; diamond = type-locality) and $T$. signatus (stars, white square $=$ type-locality) (some symbols represent more than one locality or lot of specimens).

Table 4. Morphometrics of Triportheus rotundatus. Range includes measurements of 40 non-type specimens: INHS73448 (2), INHS 65721(6), USNM307076 (3 of 4), FMNH 56502 (2), UMMZ 66469 (4 of 10), USNM 303124 (2), INHS 37104(4), INHS 37161 (1), INHS 37031 (1), USNM 302528 (3), USNM 317745 (3), USNM 310303 (2 of 3), USNM 326861 (1), MUSN 4875(3), MUSN 8757 (3).

\begin{tabular}{|c|c|c|c|c|}
\hline Character & Neotype & $\mathrm{N}$ & Range & Mean \\
\hline Standard length $(\mathrm{mm})$ & 97.8 & 40 & $39.1-178.0$ & 85.0 \\
\hline \multicolumn{5}{|c|}{ Percents of standard length } \\
\hline Bony head length & 24.2 & 40 & 21.4-29.2 & 26.3 \\
\hline Snout to anal-fin origin & 76.4 & 40 & $68.6-76.1$ & 72.4 \\
\hline Snout to dorsal-fin origin & 61.5 & 40 & $58.0-66.4$ & 62.3 \\
\hline Snout to pelvic-fin origin & 55.2 & 40 & $46.7-58.2$ & 54.6 \\
\hline Anal-fin base & 24.6 & 40 & $23.8-29.2$ & 26.6 \\
\hline Caudal peduncle length & 6.9 & 40 & $5.3-8.8$ & 7.0 \\
\hline Caudal peduncle depth & 10.8 & 40 & $7.7-11.2$ & 9.9 \\
\hline Depth at dorsal-fin origin & 38.6 & 39 & $29.7-40.1$ & 35.7 \\
\hline Depth at pectoral fin & 39.6 & 40 & $34.0-39.9$ & 37.8 \\
\hline Dorsal-fin length & 20.6 & 39 & $18.0-21.2$ & 19.8 \\
\hline Pelvic-fin length & 16.4 & 40 & $10.7-19.2$ & 15.1 \\
\hline Pectoral-fin length & 42.0 & 40 & $31.4-43.5$ & 38.5 \\
\hline \multicolumn{5}{|c|}{ Percents of head length } \\
\hline Snout length & 20.9 & 40 & $16.6-23.2$ & 20.5 \\
\hline Upper jaw length & 24.7 & 40 & $20.4-27.3$ & 24.0 \\
\hline Horizontal eye diameter & 25.6 & 40 & $21.8-30.2$ & 27.4 \\
\hline Least interorbital width & 35.4 & 40 & $26.3-37.2$ & 32.4 \\
\hline
\end{tabular}

Coloration in alcohol. Overall ground color yellowish and overlain by guanine. Snout and dorsal portion of the head dark. Scattered dark chromatophores present on opercle and infraorbitals 5 and 6. Body darker dorsally and over anal-fin base and caudal peduncle. Dorsolateral portion of body with
5 or 6 sinuous, brown, longitudinal stripes. Dark chromatophores distributed over all fins. Dorsal-fin rays outlined by dark chromatophores. Chromatophores distributed over pectoral fin between rays; with more intense pigmentation present on first unbranched ray. Anal-fin margin dark. Middle caudalfin rays very dark.

Distribution. Rio Amazonas drainage (Fig. 4).

Remarks about type specimens. The type material of $C$. rotundatus is apparently lost. No specimens identified as types of Chalceus rotundatus are listed in the BMNH registers (Anne-Marie Hodges, BMNH; pers. comm.). Chalceus rotundatus was described based on material collected by Schomburgk, the type-locality cited in the original description as the "river Padauari", an Amazon River tributary near the Guiana-Venezuela border. According to Papavero (1971:304), Schomburgk collected twice in Guyana, between 1834 and 1839, and from 1840 to 1844 . During the latter trip he also explored the Orinoco river. Unfortunately, it is not clear where Schomburgk collected and it was not possible to locate a Padauari river in any of the countries Schomburgk traveled. The drawing provided by Schomburgk is almost useless in terms of identifying the species he collected. A specimen collected in the Amazonas basin (MCP 34863, rio Purus, lago Amapá), is herein designated as a neotype for Triportheus rotundatus. This represents the species that best fits in the original description of $T$. rotundatus as for as overall body shape and number of lateral line scales.

Type-material examined. Triportheus rotundatus: Neotype by present designation, MCP 34863, 97.83 mm SL, Brazil, Acre, Rio Purus drainage, lago Amapá, UFAC, 20 Dec 2001 (10²’36’'S, 6750’24’W).

Non-type material. Bolivia: Beni: INHS 37104 (4), Cuneta (borrow pit); INHS 37161 (1), río Moseruna; INHS 37031 (1), río Matos; UMMZ 66469 (4 of 10), Lago Rogoagua and lagoons nearby (135' 'S, 66 $58^{\circ}$ 'W); USNM 303124 (2), lago Normandi, 40 km E

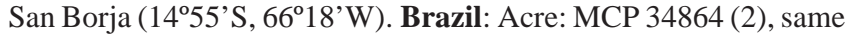
locality as neotype. Amazonas: INHS 73448 (2), lago Janauacá channel between lago Murumuru and Janauacá, about $42 \mathrm{~km} \mathrm{SW}$ Manaus ( $3^{\circ} 25^{\prime}$ S, $60^{\circ} 16^{\prime \prime}$ 'W); INHS 65721 (6), lago Janauacá channel between lago Murumuru and Janauacá, about $42 \mathrm{~km}$ SW Manaus ( $3^{\circ} 25^{\prime}$ S, $\left.60^{\circ} 16^{\prime \prime \prime} \mathrm{W}\right)$; USNM 307076 (3 of 4), Paraná of Ilha de Marchantaria (44'S, 59 $\left.7^{\circ} \mathrm{W}\right)$; FMNH 56502 (2), Santarém (0`57’S, 4659'W). Peru: Madre de Dios: USNM 302528 (3) Manu; Cocha Salvador, oxbow lake off río Manu about 1 hour down river from Pakitza (12¹6’S, 7050'W); USNM 317745 (3), Manu, Manu National Park, Pakitza, Cocha Chica, close to Quebrada Pachija; USNM 319303 (2 of 3), Manu, Manu National Park, Pakitza, Río Manu close to Pachija mouth (7¹6'S, 7646'W); USNM 326861 (1), Manu, Manu National Park, Pakitza, Río Manu close to Pachija mouth ( $\left.7^{\circ} 16^{\prime} \mathrm{S}, 76^{\circ} 46^{\prime} \mathrm{W}\right)$; MUSM 4875 (3), Manu, Cocha Salvador (12 $16^{\prime}$ S, 7050'W); MUSM 8757 (3), Tambopata, Zona Reservada Tambopata Candano, río de la Torre, Cocha La Torre (1243'S, 69 $\left.11^{\prime} \mathrm{W}\right)$. 


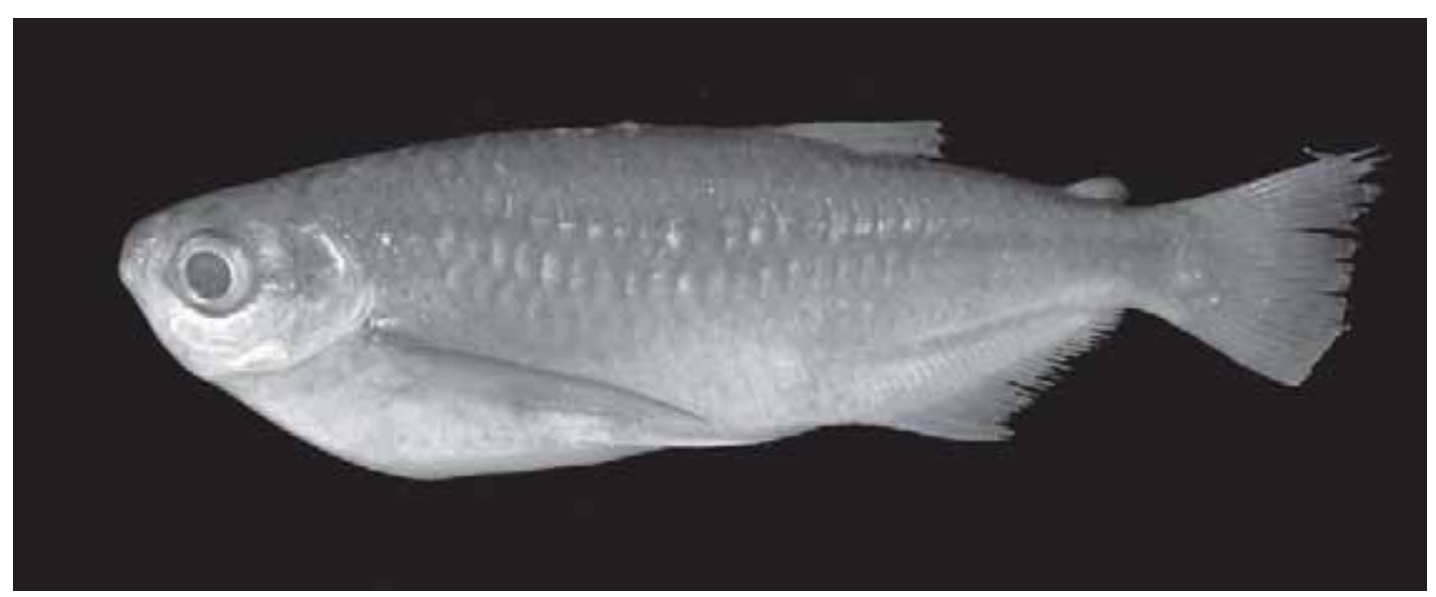

Fig. 5. Triportheus brachipomus, INHS 49094, 133.57 mm SL, Guyana, Demerara River, 8 km SSW Linden.

\section{Triportheus brachipomus (Valenciennes, in Cuvier \& Valenciennes, 1850)}

Figs. 5 and 6

Chalcinus brachipomus Valenciennes in Cuvier \& Valenciennes, 1850:259-262. Garman, 1890 (synonym of Chalcinus angulatus). Ulrey, 1895:294 (synonym of Chalcinus angulatus). Eigenmann, 1910:440 (designated as type-species of Chalcinus). Eigenmann, 1912:377 (synonym of Chalcinus rotundatus). Fowler, 1950:359 (synonym of Triportheus rotundatus).

Chalcinus brachypomus. (misspelling or unjustified emendation) Günther, 1864:341. Eigenmann, 1910:440 (synonym of Chalcinus angulatus). Eigenmann, 1912:377 (synonym of Chalcinus rotundatus). Eigenmann \& Allen, 1942:260-261 (synonym of Chalceus angulatus); 262 (synonym of Chalcinus rotundatus). Géry, 1977:343, 672 (synonym of Triportheus rotundatus). Portugal, 1990:91 (synonym of Triportheus rotundatus).

Chalcinus brachypoma. Eigenmann \& Eigenmann, 1891:56 (synonym of Chalcinus angulatus).

Chalcinus trachypomus. (error) Regan, 1911:19.

Characinus brachyformes. (error) Travassos, 1951: 284

Diagnosis. An elongate Triportheus species reaching 219 $\mathrm{mm} \mathrm{SL}$ (depth at dorsal-fin origin, 24.9-32.4\% SL; depth at pectoral-fin insertion, 27.5-34.1\% SL). The presence of 1 longitudinal scale row between the pectoral-fin insertion and the ventral keel distinguish this species from all deep bodied Triportheus species all of which have two longitudinal scale rows between the pectoral-fin insertion and the ventral keel. The combination of the possession of 32-38 lateral line scales, 22-28 branched anal-fin rays, 32-40 gill rakers on the lower limb of first arch distinguishes $T$. brachipomus from elongate congeners except by T. albus. T. brachipomus is distinguished from $T$. albus by the length of the postorbital region of the head (36.1-44.6\% of HL, mean $=39.9, \mathrm{n}=30$ versus $43.3-48.9 \%$ of $\mathrm{HL}$, mean $=45.8, \mathrm{n}=30$ in T. albus), and the distance from the insertion of posterior most dorsal-fin ray to the adipose-fin origin (14.5-21.2\% of $\mathrm{SL}$, mean $=17.4, \mathrm{n}=30$ versus $20.2-23.2 \%$ of SL, mean $=21.4$, $\mathrm{n}=30$ in $T$. albus).

Description. Morphometric data for Triportheus brachipomus presented in Table 5. Body elongate and compressed laterally. Greatest body depth located slightly posterior to vertical through pectoral-fin insertion. Dorsal profile of head slightly convex from upper lip to nares; nearly straight from nares to rear of head. Dorsal profile of body gently convex from rear of head to dorsal-fin origin; posteroventrally slanted along dorsal-fin base; straight from posterior end of dorsal fin to caudal peduncle; slightly concave along caudal peduncle. Dorsal portion of body transversely rounded.

Ventral profile of head vertical and straight from dorsal border of lower lip to anteroventral margin of dentary; posteroventrally slanted from that point to joint with quadrate. Ventral profile of body distinctly convex from isthmus to pelvic-fin insertion; nearly straight from that point to anal-fin insertion; posterodorsally slanted along anal-fin base; slightly concave along caudal peduncle. Prepelvic region ventrally expanded with midventral keel.

Head obtusely pointed in profile; snout straight in profile. Mouth terminal; lower jaw slightly longer than upper jaw. Nostrils of each side close together; anterior opening circular; posterior kidney-shaped. Eye large, without adipose eyelid.

Premaxillary teeth in 2 rows. Outer row with 5 pentacuspidate teeth and somewhat irregular. Seven teeth on inner row in premaxilla; 2 medial teeth smaller than other teeth in series; teeth of inner row larger. Teeth on maxilla 2-3, smaller than those on premaxilla and tricuspidate. Teeth on lower jaw in two rows, 6 teeth with 5-7 cusps on outer row; inner row with conical symphyseal tooth.

Scales cycloid, thin, and large. Lateral line distinctly decurved ventrally, completely pored from supracleithrum to base of caudal-fin rays. Thirty-two to 38 (mean $=35.4, \mathrm{n}=39$ ) scales in lateral line (50\% of specimens with $36-37$ scales); 5 
scale series between lateral line and dorsal-fin origin; 2 scale rows between lateral line and pelvic-fin insertion. Large scale row between pectoral-fin insertion and midventral keel; 12-17 (mean $=14.6, \mathrm{n}=28)$ scales along mid-dorsal line between tip of supraoccipital spine and dorsal-fin origin. Four rows of scales on caudal peduncle.

Dorsal-fin rays ii,9; anal-fin rays iii,22-28 [26] $($ mean $=24.9$, $\mathrm{n}=45$ ); pectoral-fin rays i,12-13 [12]; pelvic-fin rays i,6. Dorsal-fin margin straight, dorsal-fin base situated on posterior one-half of body; base of last dorsal-fin ray located anterior to vertical through anal-fin origin. Pectoral fins large and extending posteriorly past one-half length of pelvic fin. First branched anal-fin ray longest; following rays rapidly decreasing in length. Caudal emarginate, nearly forked, scaled only at base. Middle caudal-fin rays extended slightly beyond posterior margin of remainder of fin.

Total vertebrae $37-38$ [38].

Coloration in alcohol. Overall ground color yellowish brown. Snout, lower lip, and dorsal portion of head dark. Dorsolateral portion of postorbital region with scattered, small, dark chromatophores. Body with mid-lateral dark stripe extending from supracleithrum posteriorly to caudal peduncle; posterior portion of stripe vertically expanded and broadened into distinctly wider diffuse dark spot on lateral surface of caudal peduncle. Body darker dorsal to stripe. Dark chromatophores forming a diffuse and posterodorsally inclined stripe situated above analfin base. Stripe distinctly separated from anal fin base anteriorly, and approaching base posteriorly. Dorsal and pectoral-fin rays outlined by dark chromatophores. Distal tips of anal-fin rays dark. Caudal-fin rays outlined by series of dark chromatophores.

Distribution. Río Orinoco, Essequibo River, Demerara River, Courantijne River, Maroni River and rio Araguari drainages (Fig. 2).

Remarks about type specimens. There are three lots identified as syntypes of Chalcinus brachipomus at MNHN. Two specimens (MNHN 5402) brought from Mana by M. Dourmec Leschenault, and two lots, MNHN A 9916, 5 specimens, and MNHN A 9836, 1 specimen, both from the Essequibo River by Schomburgk. An examination of the material revealed the presence of two species among the syntypes, with the specimens in MNHN 5402 and MNHN 9836 belonging to a different species than MNHN A 9916. The original description of Chalcinus brachipomus includes few features that are useful to determine that the specimens in MNHN 5402 and MNHN 9836 served as the basis of the original description of the species. Proportions of body depth in total length, head length in total length, eye diameter in head length and dorsal fin position cited in the original description are coincident with those presented by the specimens in the lots MNHN A 9836 and MNHN 5402. One of the specimens registered as MNHN 5402 is designated herein as the lectotype of Chalcinus brachipomus, and numbered as MNHN 2004-3095 (Fig. 6). Remaining specimens of the lot MNHN 5402 and MNHN A
9836 become paralectotypes. The original syntypes numbered MNHN A 9916 are also paralectotypes, but are herein identified as Triportheus angulatus.

Type-material examined. Chalcinus brachipomus: Lectotype by present designation, MNHN 2004-3095, $219 \mathrm{~mm}$ SL, French Guyana, Mana, Dourmec Leschenault, 1824. Paralectotypes, MNHN 5402 (1), 175 mm SL, French Guyana, Mana, Dourmec Leschenault, 1824 [544'N, 53⒌'W]. MNHN A 9836, 180 mm SL, Essequibo river drainage, Guyana, R. H. Schomburgk, 1847. MNHN A 9916 (5), 125-185 mm SL, [specimens originally designated as syntypes of Chalcinus brachipomus but belonging to Triportheus angulatus].

Non-type material: Brazil: Amapá: MZUSP 58855 (7 of 13), channel of rio Araguari, município Ferreira Gomes $\left(0^{\circ} 08^{\prime} \mathrm{N}, 51^{\circ} 13^{\prime} \mathrm{W}\right)$. French Guyana: NRM 28397 (1), Maroni, St-Laurent-du-Maroni, Maroni River: small tributaries on French Guiana side and left bank island on Suriname

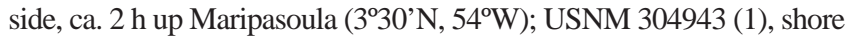
of Maroni River by ban Shore of Grand Santi (4 $\left.4^{\circ} 15^{\prime} \mathrm{N}, 54^{\circ} 22^{\prime} \mathrm{W}\right)$. Guyana: AUM 27844 (6), Mazaruni-Potaro River drainage (5'59'N, $58^{\circ} 33^{\prime} \mathrm{W}$ ); INHS 49320 (3) Mazaruni-Potaro drainage (5'59' N, 58 33' W); AUM 27940 (2), Demerara River 5.05 mi SSW Linden (556'N, 58 $18^{\prime}$ 'W); INHS 49094 (3), 5 mi SSW Linden, Demerara River (05 $56^{\prime} 0^{\prime} \mathrm{N}, 58^{\circ} 18^{\prime} 22^{\prime}$ W); AUM 27791 (1 of 2), Mazaruni-Potaro, Essequibo River, beach $0.72 \mathrm{mi}$ SW Rockstone (5'58' N, 58 $33^{\circ} \mathrm{W}$ ); INHS 49232 (3), Essequibo River, beach 0.72 mi SW Rockstone (5'58'N, 5833'W); AUM 28012 (2), Mazaruni-Potaro, large sandbar and small cataract, 31.9 mi S Rockstone (5³1'N, 58³7’ W); AUM 28061 (3), Potaro River at beach on $\mathrm{N}$ bank, downstream of Tumatumari cataract

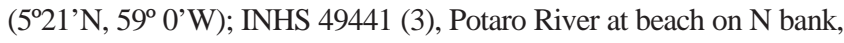
downstream of Tumatumari cataract $\left(5^{\circ} 21^{\prime} \mathrm{N}, 5^{\circ} 0^{\prime} \mathrm{W}\right)$; AUM 28091 (2), Mazaruni-Potaro, Creek on N side of Potaro River ( $\left.5^{\circ} 21^{\prime} \mathrm{N}, 5^{\circ} 0^{\prime} \mathrm{W}\right)$; FMNH 53592 (5), Crab Falls, (6² $\left.15^{\prime} \mathrm{N}, 58^{\circ} 47^{\prime} \mathrm{W}\right)$; FMNH 7554 (1) Crab Falls, Essequibo River (6 $\left.{ }^{\circ} 15^{\prime} \mathrm{N}, 58^{\circ} 47^{\prime} \mathrm{W}\right)$; FMNH 53591 (2), Bartica $\left(6^{\circ} 24^{\prime} \mathrm{N}, 58^{\circ} 37^{\prime} \mathrm{W}\right)$; FMNH 53590 (1), Wismar $\left(6^{\circ} 0^{\prime} \mathrm{N}\right.$, $\left.58^{\circ} 18^{\prime} \mathrm{W}\right)$. Suriname: USNM 225628 (1), Matappi Creek ( $5^{\circ} 1^{\prime} \mathrm{N}$, 57¹7'W); USNM 225280 (1), Nickerie District; Creek About 2 km N

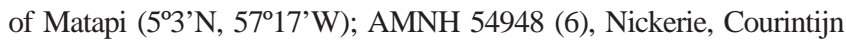
river, Camp Hydro, $30 \mathrm{~km}$ north of Tiger Falls ( $\left.3^{\circ} 58^{\prime} \mathrm{N}, 58^{\circ} 1^{\prime} \mathrm{W}\right)$; AMNH 220999 (2), Marowijne Albina (5³0’N, 54²'W); AMNH 221001 (1), Marowijne, Litani river, Third compound ( $\left.3^{\circ} 17^{\prime} \mathrm{N}, 54^{\circ} 5^{\prime} \mathrm{W}\right)$. Venezuela: Amazonas: FMNH 103913 (11), pool behind beach of río Ventuari on S side of river, about $12 \mathrm{~km}$ above mouth in Río Orinoco laguna Pavon (44'N, 6656'W); FMNH 103911 (1), pool behind beach of rio Ventuari on south side of river, $5 \mathrm{hr}(12 \mathrm{~km})$ above mouth in Río Orinoco laguna Pavon (4º' N, 66 56 ' W); FMNH 103903 (7), caño Tuparero, above San Francisco de Atabapo, in Río Orinoco ( $4^{\circ} 2^{\prime} \mathrm{N}$, $\left.67^{\circ} 42^{\prime} W\right)$. Apure: INHS 98928 (1), caño San Miguel, Río Cinaruco (6³ $\left.34^{\prime} \mathrm{N}, 67^{\circ} 17^{\prime} \mathrm{W}\right)$.

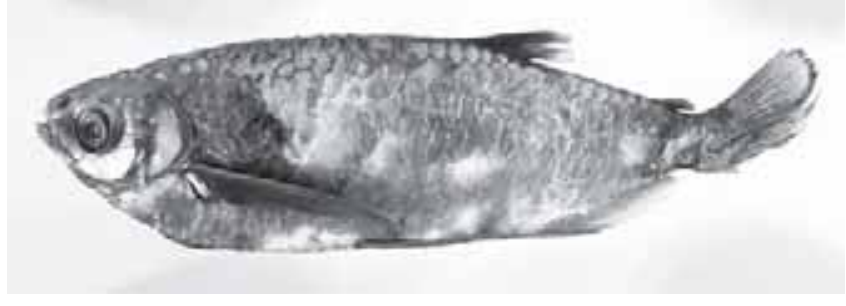

Fig. 6. Chalcinus brachipomus, lectotype, MNHN 2004-3095, $219 \mathrm{~mm}$ SL, French Guiana. 
Table 5. Morphometrics of Triportheus brachipomus. Described ranges include measurements of 40 non-type specimens: AUM 27791 (2), AUM 27844 (6), AUM 27940 (2), AUM 28012 (2), AUM 28061 (3), AUM 28091 (2), INHS 49232 (3), INHS 49320 (3), INHS 49441 (3), INHS 49094 (1 of 3), NRM 28397 (1), USNM 225280 (1), USNM 225628 (1), USNM 304943 (1), AMNH 54948 (6), AMNH 220999 (2), AMNH 221001 (1).

\begin{tabular}{lcccc}
\hline \multirow{2}{*}{ Character } & \multirow{2}{*}{ Lectotype Paralectotypes } & \multicolumn{2}{c}{ Non-types } \\
\cline { 3 - 5 } & \multicolumn{3}{c}{ Range } & Mean \\
\hline Standard length (mm) & 219 & $175.0-180$ & $43.4-184.5$ & 89.7 \\
& Percents of standard length & & \\
Bony head length & 23.7 & $22.2-23.1$ & $22.5-27.6$ & 24.7 \\
Snout to anal-fin origin & 74.0 & $68.7-70.3$ & $66.9-76.5$ & 71.7 \\
Snout to dorsal-fin origin & 64.0 & $55.4-61.3$ & $56.8-66.4$ & 61.9 \\
Snout to pelvic-fin origin & 50.5 & $47.3-48.1$ & $48.5-55.6$ & 52.2 \\
Anal-fin base & 24.9 & $20.1-23.5$ & $21.8-26.2$ & 24.0 \\
Caudal peduncle length & 6.9 & $6.8-7.2$ & $5.2-11.0$ & 7.6 \\
Caudal peduncle depth & 7.8 & $7.6-8.5$ & $7.1-9.7$ & 8.7 \\
Depth at dorsal-fin origin & 30.4 & $27.7-27.8$ & $24.9-32.4$ & 28.3 \\
Depth at pectoral fin & 30.7 & $26.5-27.8$ & $27.5-34.1$ & 30.4 \\
Dorsal-fin length & 15.7 & $15.3-16.1$ & $13.9-20.5$ & 17.4 \\
Pelvic-fin length & 13.9 & $13.3-13.5$ & $10.8-19.2$ & 14.2 \\
Pectoral-fin length & 32.7 & $31.2-32.1$ & $29.4-37.0$ & 33.2 \\
& Percents of head length & & \\
Snout length & 24.9 & $24.7-25.5$ & $19.8-25.0$ & 22.1 \\
Upper jaw length & 23.6 & $23.1-23.5$ & $19.7-27.9$ & 24.7 \\
Horizontal eye diameter & 31.4 & $30.1-35.8$ & $28.4-35.2$ & 31.6 \\
Least interorbital width & 34.7 & $32.0-32.2$ & $25.7-34.1$ & 30.5 \\
\hline
\end{tabular}

\section{Triportheus auritus (Valenciennes, in Cuvier \& Valenciennes, 1850)} Fig. 7

Chalcinus auritus Valenciennes, in Cuvier \& Valenciennes, 1850:262-263 (description).

Triportheus auritus. Fowler, 1950:357 (synonymy; Brazil, Amazonas, rio Araguaia).

Chalcinus elongatus Günther, 1864:342 (description; typelocality: "?").

Triportheus elongatus. Fowler, 1945:153 (listed with synonyms, for Peru).

Chalcinus cruzi Miranda-Ribeiro, 1941: 173 (description, Brazil, rio Amazonas).

Chalcinus amazonensis Miranda-Ribeiro, 1941:174 (description, Brazil, no type-locality)

Diagnosis. An elongate Triportheus species reaching 242 $\mathrm{mm}$ SL (depth at dorsal-fin origin, 22.5-28.8 \% SL; depth at pectoral-fin insertion, 24.8-32.0\% SL). The presence of 1 longitudinal scale row between the pectoral-fin insertion and ventral keel distinguish this species from all deep-bodied Triportheus species that have 2 longitudinal scale rows between the pectoral-fin insertion and ventral keel. Triportheus auritus is distinguished from all elongate and deep-bodied Triportheus species by the combination of the small number of gill rakers on the lower limb of first gill arch (22-28, mean = $24.8, \mathrm{n}=39)$ and the high number of lateral-line scales $(40-46$, mean $=43.9, \mathrm{n}=36$ ).
Description. Morphometric data of Triportheus auritus presented in Table 6. Body elongate and compressed laterally. Greatest body depth located slightly posterior to vertical through pectoral-fin insertion. Dorsal profile of head slightly convex from upper lip to nares; nearly straight from nares to rear of head. Dorsal profile of body nearly straight from rear of head to dorsal-fin origin; posteroventrally slanted along dorsal-fin base; less inclined from posterior terminus of dorsal fin to caudal peduncle; slightly concave along caudal peduncle. Dorsal portion of body transversely rounded.

Ventral profile of head vertically straight from dorsal border of lower lip to anteroventral margin of dentary; straight from that point to joint with quadrate. Ventral profile of body arched from isthmus to pelvic-fin insertion; slightly curved to nearly straight from that point to analfin origin; posterodorsally slanted along anal-fin base; slightly concave along caudal peduncle. Prepelvic region ventrally expanded with midventral keel; kell extending to anal-fin origin.

Head pointed in profile. Mouth terminal; lower jaw as long as upper jaw. Nostrils of each side close together; anterior opening circular; posterior kidney-shaped. Eye large, without adipose eyelid.

Gill rakers thick and separated, gill-raker length about one-half length of branchial filament; gill rakers on lower limb of first arch 22-28 [25] ( mean $=24.8, \mathrm{n}=39)$.

Teeth on premaxilla in 3 rows; teeth of inner row larger. Outer row formed by 5 pentacuspidate teeth; middle row with 2 teeth, inner row with 6 teeth. Maxilla with 2-4 teeth, smaller than smallest teeth on premaxilla. Teeth on lower jaw in 2 rows with 5-6 teeth with 5-7 cusps in outer row and inner row consisting of single conical symphyseal tooth.

Scales cycloid, thin, and large. Lateral line distinctly decurved ventrally, completely pored from supracleithrum to base of caudal-fin rays. Forty to 46 [43] $($ mean $=43.9, n=36)$ scales in lateral line; 6 scale series between lateral line and dorsal-fin origin; 2 scale rows between lateral line and pelvic-fin insertion. One large scale row between pectoral-fin insertion and midventral keel; 14-20 [19] (mean = 17.6, $\mathrm{n}=$ 31) scales along mid-dorsal line between tip of supraoccipital spine and dorsal-fin origin. Five rows of scales on caudal peduncle.

Dorsal-fin rays ii,9; anal-fin rays iii,24-28 [28] (mean = $26.2, \mathrm{n}=39)$; pectoral-fin rays i,11-13 [11] $($ mean $=11.9, \mathrm{n}=$ 39); pelvic-fin rays i,6. Dorsal-fin margin straight, dorsal-fin base situated on posterior one-half of body; base of last dorsal-fin ray located anterior to vertical through anal-fin origin. Pectoral large, extending posteriorly as far as mid length of pelvic fin. First branched anal-fin ray longest; following rays rapidly decreasing in length. Caudal truncate, scaled only at base. Middle caudal-fin rays extended slightly beyond posterior margin of remainder of fin.

Total vertebrae 43-44. 


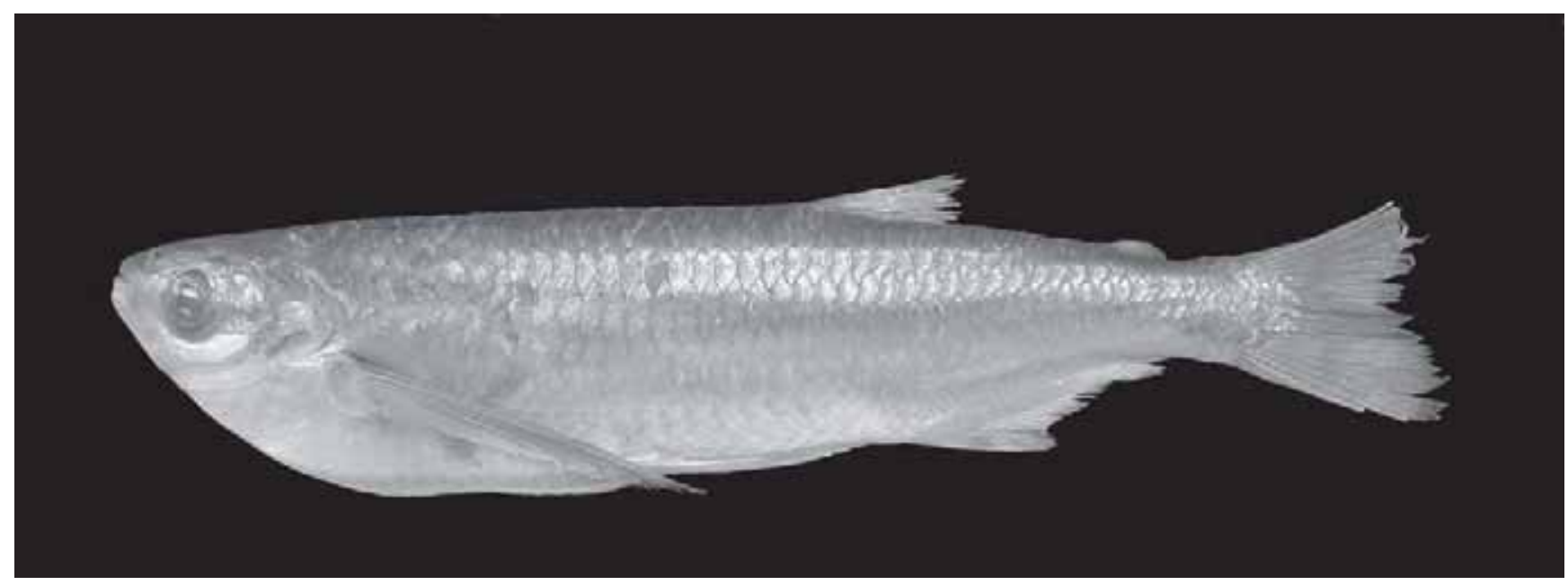

Fig. 7. Triportheus auritus, neotype, MZUSP 58859, 185.9 mm SL, Brazil, Amazonas, rio Negro, Anavilhanas.

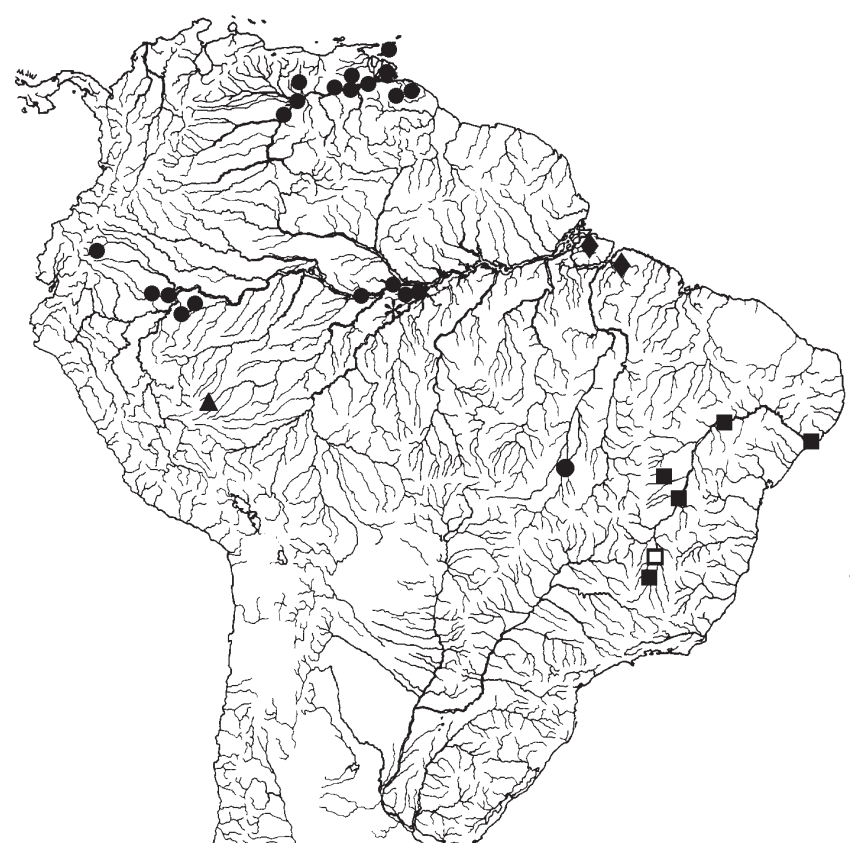

Fig. 8. Map of central and northern South America showing geographic distribution of Triportheus auritus (circles; asterisk = neotype locality), T. guentheri $($ black squares; white square $=$ type-locality) and $T$. curtus (triangle; diamond = syntype-localities) (some symbols represent more than one locality or lot of specimens).

Coloration in alcohol. Overall ground color yellowish brown. Snout, lower lip, and dorsal portion of head dark. Scattered dark chromatophores present on all head bones. Body with mid-lateral dark stripe extending from supracleithrum posteriorly to caudal peduncle; stripe becoming diffuse posteriorly and broadened into distinctly wider diffuse dark spot on lateral surface of caudal peduncle. Body darker brown dorsal to midlateral stripe. Dorsal margin of body dark. All fins pigmented along rays. Dorsal and pectoral-fin rays outlined by dark chromatophores. Distal tips of anal-fin rays darker. Caudal-fin rays outlined by series of dark chromatophores.
Distribution. Rio Amazonas, Tocantins, and Araguaia basins, río Orinoco basin, Trinidad (Fig. 8).

Remarks about type-specimens. Cuvier \& Valenciennes (1849:263) noted that "[the length of our fish is six pounces. The specimens deposited in the collection of the museum were collected in the Amazon by Mr. Castelnau] (my translation). No specimens identified as Chalcinus auritus with these data were located in the holdings of MNHN (where the specimens were supposed to belong). A neotype collected in the rio Amazonas drainage (MZUSP 58859, rio Negro, Anavilhanas), is designated herein for Triportheus auritus. That species as defined herein best fits the original description by Valenciennes, in terms of overall body and head shape, and counts of the lateral-line scales and anal-fin rays.

Type-material examined. Triportheus auritus: Neotype by present designation, MZUSP 58859, 185.9 mm SL, Brazil, Amazonas, rio Negro, Anavilhanas, M. Goulding, Oct 1979 (242’ S, 6045' W).

Chalcinus elongatus: holotype, BMNH 1852.9.13:10, no locality. Günther (1864:342) in the original description of Chalcinus elongatus refers to the type-material as being "From the Collection of the Zoological Society" and the distribution as "Hab._??". A specimen identified as the holotype of Chalcinus elongatus is housed in BMNH (BMNH 1852.9.13:10).

Chalcinus amazonensis: holotype, MNRJ 2771, rio Amazonas, M. Lobato.

Chalcinus cruzi: holotype, MNRJ 2775, South America, O. Cruz.

Non-type material. Brazil: Amazonas: USNM 229127 (2), near Manaus, lago Janauari, lago Canta Galos ( $3^{\circ} 12^{\prime}$ S, $\left.60^{\circ} 1^{\prime} \mathrm{W}\right)$; USNM 307147 (3), Ressaca da Ilha de Marchantaria (4²' S, 59 $7^{\circ} \mathrm{W}$ ); USNM 307137 (1), lago Canta Galos, lago Janauari ( $3^{\circ} 12^{\prime}$ 'S, $\left.60^{\circ} 1^{\prime} \mathrm{W}\right)$; USNM 311094 (1), rio Solimões between Manaus and Tefé (322'S, 64²1'W); USNM307103 (1), paraná da Ilha de Marchantaria (44'S, 59 $9^{\circ}$ 'W); INHS 71472 (4), lago Janauari about $8 \mathrm{~km} \mathrm{SW}$ Manaus (312'S, 60¹'W); INHS 73035 (3), lago Marchantaria, Camaleão inlet, Marchantaria Island, 
Table 6. Morphometrics of Triportheus auritus. Ranges include measurements of type specimens (C. auritus (A), C. cruzi (B) and C. amazonensis (C)) and 68 non-type specimens: NRM 30941 (1), NRM 30487 (1), USNM 280493 (1), USNM 280508 (1), USNM 280625 (1), INHS 39760 (1), USNM 280492 (1), USNM 280494 (2), INHS 40370 (6), INHS 38943 (1 of 9), USNM 229127 (2), USNM 307147 (3), USNM 307137 (1), USNM 311094 (1), USNM 307103 (1), INHS71472 (4), INHS 73035 (3), INHS 67386 (2), USNM 307117 (2), USNM 307139 (3 of 8), USNM 233639 (6), FMNH 103056 (10), FMNH 7496 (2), FMNH 103902 (1), USNM 233227 (2), UMMZ 211304 (4), AMNH 217731 (5).

\begin{tabular}{lccccc}
\hline \multirow{2}{*}{ Character } & & & & \multicolumn{2}{c}{ Non-types } \\
\cline { 3 - 6 } & $\mathrm{A}$ & $\mathrm{B}$ & $\mathrm{C}$ & Range & Mean \\
\hline Standard length (mm) & 185.9 & 175.0 & 229.2 & $60-242.0$ & 119.5 \\
& $\begin{array}{c}\text { Percents of } \\
\text { Btandard length }\end{array}$ & & \\
Bony head length & 20.0 & 21.7 & 20.0 & $20.0-25.4$ & 22.8 \\
Snout to anal-fin origin & 72.3 & 72.9 & 75.0 & $68.0-76.9$ & 73.9 \\
Snout to dorsal-fin origin & 60.5 & 63.7 & 62.8 & $60.1-66.4$ & 64.0 \\
Snout to pelvic-fin origin & 49.8 & 48.9 & 49.7 & $48.8-54.7$ & 52.0 \\
Anal-fin base length & 20.1 & 20.5 & 20.6 & $19.1-25.4$ & 21.7 \\
Caudal peduncle length & 9.3 & 7.3 & 7.2 & $4.0-10.2$ & 6.4 \\
Caudal peduncle depth & 7.6 & 7.8 & 7.8 & $6.9-8.6$ & 7.9 \\
Depth at dorsal-fin origin & 22.6 & 22.7 & 23.6 & $22.5-28.8$ & 24.9 \\
Depth at pectoral fin & 24.8 & 24.6 & 25.2 & $24.8-32.0$ & 27.9 \\
Dorsal-fin height & 15.0 & 15.0 & 14.0 & $13.4-18.6$ & 15.7 \\
Pelvic-fin length & 14.6 & 14.3 & 13.6 & $12.3-16.0$ & 14.3 \\
Pectoral-fin length & 33.7 & 35.2 & 33.6 & $31.9-41.6$ & 35.6 \\
& Percents of head length & & \\
Snout length & 26.0 & 22.3 & 22.5 & $17.0-26.8$ & 21.2 \\
Upper jaw length & 26.5 & 24.4 & 24.4 & $20.6-32.6$ & 24.7 \\
Horizontal eye diameter & 33.5 & 29.9 & 28.5 & $23.8-35.8$ & 29.2 \\
Least interorbital width & 33.1 & 29.7 & 31.2 & $28.0-34.1$ & 31.0 \\
\hline
\end{tabular}

about $12 \mathrm{~km} \mathrm{~S}$ Manaus (44'S, 597'W); INHS 67386 (2), lago Canta Galos off lago Janauari, about 8 km SW Manaus (3¹2'S, $\left.60^{\circ} 1^{\prime} \mathrm{W}\right)$; USNM 307117 (2), Ressaca da Ilha de Marchantaria (44'S, 59 $7^{\circ} \mathrm{W}$ ); USNM 307139 (3 of 8), Ressaca da Ilha de Marchantaria (44'S, 597’W); MZUSP 19768 (9), lago Janauacá. Mato Grosso: MCP s/n (3), rio Araguaia, Barra do Garças (16 $20^{\circ} \mathrm{S}$, $\left.52^{\circ} 41^{\prime} \mathrm{W}\right)$. Pará: FMNH 56501 (1), Santarém (057'S, 4659'W). Goiás: MCP 17212 (5), Rio Araguaia near Luis Alves (13¹4'S, 50³5'W). Equador: Napo: FMNH 103056 (10), río Yasuni, Laguna Jatuncocha ( $1^{\circ} 0$ 'S , 75'29'W). Guiana: FMNH 7496 (1), Morawhanna ( $\left.8^{\circ} 16^{\prime} \mathrm{N}, 59^{\circ} 45^{\prime} \mathrm{W}\right)$. Peru: Loreto: USNM 280625 (1), green water caño on left bank of río Manite, about $8 \mathrm{~km}$ upriver of junction of río Manite and rio Amazonas ( $\left.3^{\circ} 31^{\prime} \mathrm{S}, 72^{\circ} 40^{\prime} \mathrm{W}\right)$; USNM 280493 (1), río Nanay approximately $20 \mathrm{~km}$ upstream of mouth, main channel, side channels and side pools ( $\left.3^{\circ} 51^{\prime} \mathrm{S}, 73^{\circ} 1^{\prime} \mathrm{W}\right)$; USNM 280508 (1), río Itaya, main river channel and lower portions of caños, 5 to $20 \mathrm{~km}$ upstream of Belen, Iquitos ( $3^{\circ} 51^{\prime} \mathrm{S}$, 73²'W); USNM 280492 (1), Quebrada Corrientillo, at Corrientillo, on road running West From Iquitos to río Nanay ( $3^{\circ} 50^{\prime} \mathrm{S}, 73^{\circ} 13^{\prime} \mathrm{W}$ ). USNM 280494 (2), canyons entering río Nanay, Northeast of Iquitos (349'S, 7311'W); NRM 30491 (1), río Itaya drainage, Quisto Cocha, W lake margin, (3'50'S, 7316' W); NRM 30487 (1), rio Nanay drainage, Bella Vista, Vieja Cocha. INHS 39760 (1) lago Pabellon, río Orosa, Amazonas drainage, 40 min from Paucarillo (034' S, $\left.72^{\circ} 25^{\prime} \mathrm{W}\right)$; INHS 40370 (6), río Nanay Amazonas drainage, Pampa Chica, $\mathrm{N}$ edge of Iquitos $\left(03^{\circ} 44^{\prime} \mathrm{S}, 73^{\circ} 16^{\prime} \mathrm{W}\right)$; INHS 38943 (1 of 9), Iquitos dock at Requena, (03⒋ 's, $\left.73^{\circ} 14^{\prime} \mathrm{W}\right)$; USNM 176118 (1), Caño Shansho, Ampyacu (46' S, 7259’W). Trinidad:
USNM 229911 (5), Chatham at river mouth about $100 \mathrm{~m}$ upstream $\left(10^{\circ} 53^{\prime} \mathrm{N}, 61^{\circ} 52^{\prime} \mathrm{W}\right)$. Venezuela: Delta do Amacuro: USNM 233639 (6), río Orinoco, small side caño, caño Araguao, 112 Naut. mi upstream from sea buoy ( $\left.8^{\circ} 38^{\prime} \mathrm{N}, 61^{\circ} 43^{\prime} \mathrm{W}\right)$; AMNH 217731 (5), North side río Orinoco, caño on isla Guacujana, S shore. Amazonas: FMNH 103902 (1), Río Orinoco ca. 5 h above Atabapo by falca $\left(4^{\circ} 2^{\prime} \mathrm{N}, 67^{\circ} 42^{\prime} \mathrm{W}\right)$; INHS 29146 (1), río Mavaca $\left(2^{\circ} 31^{\prime} \mathrm{N}\right.$, $\left.65^{\circ} 11^{\prime} \mathrm{W}\right)$; AMNH 93061 (1), río Mavaca, $45 \mathrm{~min}$ up river from base camp ( $\left.2^{\circ} 31^{\prime} \mathrm{N}, 65^{\circ} 11^{\prime} \mathrm{W}\right)$. Monagas: FMNH 55905 (1), La Pedrita; USNM 233227 (2), isolated lagoon on isla Tapatapa, at Los Castillos, 163 Naut. mi from sea buoy ( $\left.8^{\circ} 31^{\prime} \mathrm{N}, 62^{\circ} 26^{\prime} \mathrm{W}\right)$. Bolívar: UMMZ 211304 (4), small canyons on the west side of río Arature, several km upstream from mouth, Orinoco drainage $\left(8^{\circ} 35^{\prime} \mathrm{N}\right.$, $\left.60^{\circ} 53^{\prime} \mathrm{W}\right)$; INHS 35088 (1), laguna Castillero, near río Orinoco $\left(7^{\circ} 38^{\prime} \mathrm{N}, 6^{\circ} 9^{\prime} \mathrm{W}\right)$; INHS 35220 (1), laguna Castilhero $\left(7^{\circ} 38^{\prime} \mathrm{N}\right.$, $\left.66^{\circ} 9^{\prime} \mathrm{W}\right)$. Guarico: INHS 34483 (1), río San Bartolo at Aguas Muertas (8²'N, 66² $\left.40^{\prime} \mathrm{W}\right)$. Apure: INHS 61491 (2), Cano San Miguel, río Cinaruco $\left(6^{\circ} 4^{\prime} \mathrm{N}, 6^{\circ} 17^{\prime} \mathrm{W}\right)$. Anzoategui: INHS 29281, laguna Orsinera $\left(8^{\circ} 9^{\prime} \mathrm{N}, 6^{\circ} 34^{\prime} \mathrm{W}\right)$. INHS 29267 (1), laguna las Tejitas $\left(8^{\circ} 9^{\prime} \mathrm{N}, 63^{\circ} 26^{\prime} \mathrm{W}\right)$.

\section{Triportheus trifurcatus (Castelnau, 1855) Fig. 9}

Chalcinus trifurcatus Castelnau, 1855: 70, Pl. 37, fig. 1, rio Araguaia, Brazil. Günther, 1864:340-341 (synonym of Chalcinus brachypomus). Garman, 1890:3 (synonym of Chalcinus angulatus). Eigenmann \& Eigenmann, 1891:56 (synonym of Chalcinus angulatus). Ulrey, 1895:294 (synonym of Chalcinus angulatus). Eigenmann, 1910:440 (synonym of Chalcinus angulatus). Fowler, 1950:359 (synonym of $T$. rotundatus).

Triportheus trifurcatus. Portugal, 1990:129-135 (redescription, illustration, map).

Diagnosis. A deep bodied Triportheus species reaching $165 \mathrm{~mm}$ of SL (depth at dorsal-fin origin, 27.0-36.2 \% SL; depth at pectoral-fin insertion, 31.6-39.1\% SL). The presence of 2 longitudinal scale rows between the pectoral-fin insertion and ventral keel distinguish this species from all elongate bodied Triportheus species that have 1 longitudinal scale row between the pectoral-fin insertion and the ventral keel. Triportheus trifurcatus differs from other deep-bodied Triportheus species by the combination of the number of gill rakers on the lower limb of the first gill $\operatorname{arch}(40-47$, mean $=42.1, \mathrm{n}=24)$; the number of lateral line scales $(32-35$, mean $=32.8, \mathrm{n}=20)$; and the 5 scale series dorsal to the lateral line.

Description. Morphometric data for Triportheus trifurcatus presented in Table 7. Body deep and compressed laterally. Greatest body depth located slightly posterior to vertical through pectoral-fin insertion. Dorsal profile of head straight from snout to rear of head. Dorsal profile of body gently curved from rear of head to dorsal-fin origin; posteroventrally slanted from dorsal-fin origin to caudal peduncle; slightly curved along caudal peduncle. 


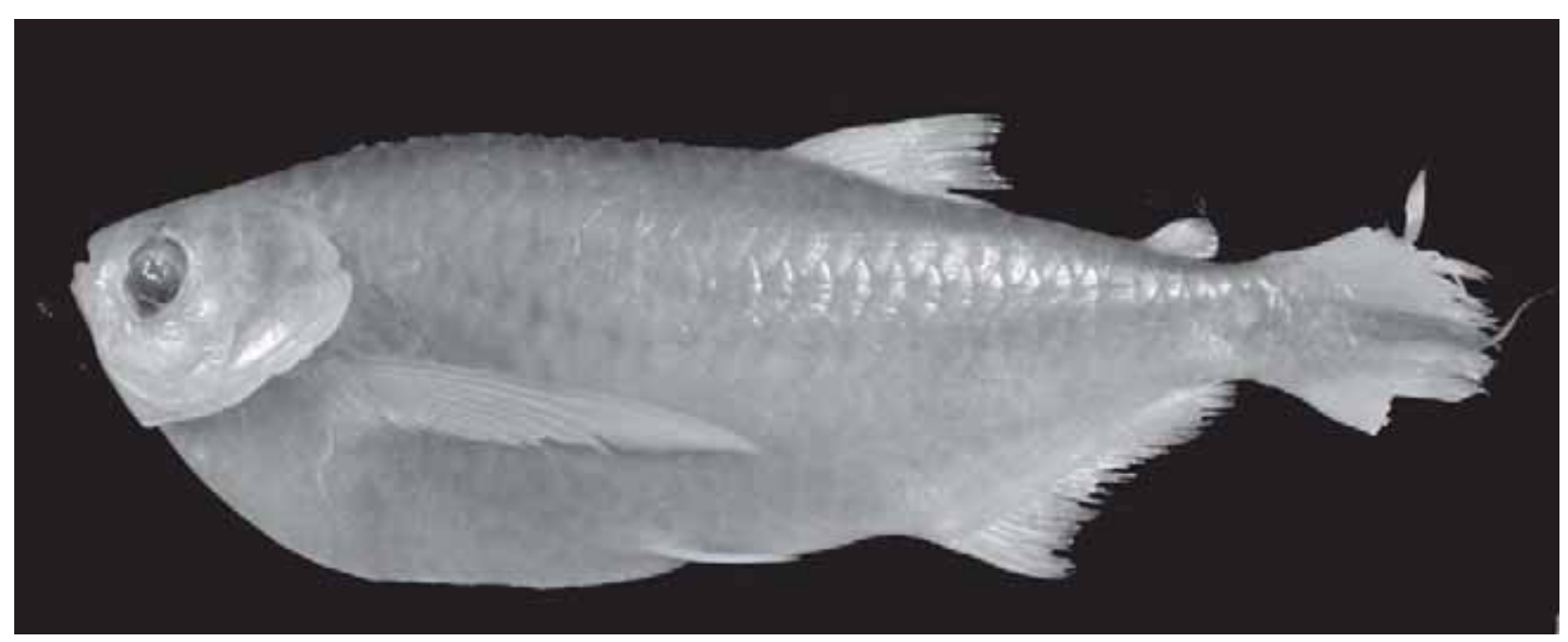

Fig. 9. Triportheus trifurcatus, MZUSP 19633, 165 mm SL, Brazil, Mato Grosso, rio Araguaia, Santa Terezinha.

Table 7. Morphometrics of Triportheus trifurcatus. Ranges include measurements of non-type specimens: MZUSP 4832 (21 of 36), MZUSP 52122 (3), MZUSP 19633 (3) and MZUSP 20640 (5). Holotype measurements obtained from X-ray.

\begin{tabular}{lcccc}
\hline \multicolumn{1}{c}{ Character } & Holotype & N & Range & Mean \\
\hline Standard length (mm) & 136.29 & 32 & $66.7-165.0$ & 92.5 \\
& Percents of standard length & \\
Bony head length & 20.98 & 32 & $24.3-28.1$ & 25.8 \\
Snout to anal-fin origin & 72.23 & 32 & $66.9-74.8$ & 70.7 \\
Snout to dorsal-fin origin & 60.12 & 32 & $56.4-62.1$ & 58.7 \\
Snout to pelvic-fin origin & 25.87 & 31 & $50.2-54.1$ & 52.5 \\
Anal-fin base length & 27.58 & 32 & $23.3-27.2$ & 24.9 \\
Caudal peduncle length & 5.62 & 32 & $6.5-9.5$ & 8.0 \\
Caudal peduncle depth & 9.30 & 32 & $7.2-9.9$ & 8.4 \\
Depth at dorsal-fin origin & 31.36 & 31 & $27.0-36.2$ & 31.2 \\
Depth at pectoral fin & 32.90 & 32 & $31.6-39.1$ & 34.3 \\
Dorsal-fin height & 17.76 & 31 & $18.4-23.2$ & 20.1 \\
Pelvic-fin length & 7.78 & 29 & $10.5-15.8$ & 13.6 \\
Pectoral-fin length & 33.89 & 32 & $34.5-42.2$ & 37.3 \\
& Percents of head length & & \\
Snout length & 22.97 & 32 & $19.6-24.1$ & 21.6 \\
Upper jaw length & & 32 & $21.7-30.0$ & 24.7 \\
Horizontal eye diameter & 38.80 & 32 & $25.1-35.2$ & 31.7 \\
Least interorbital width & & 32 & $28.2-33.7$ & 31.2 \\
\hline
\end{tabular}

Ventral profile of head straight from tip of lower lip to anteroventral margin of dentary; straight from that point to isthmus. Ventral profile of body arched from isthmus to pelvic-fin insertion; nearly convex from pelvic-fin insertion to anal-fin origin; posterodorsally slanted along anal-fin base; slightly curved along caudal peduncle. Prepelvic region ventrally expanded and flattened, with well defined keel.

Head blunt in profile; posterior margin of opercle reaching pectoral-fin insertion. Mouth terminal; lower jaw as long as upper jaw. Nostrils of each side close together; anterior opening circular; posterior elongate.

Gill rakers thin and close together, almost so long as branchial filament length; gill rakers on lower limb of first arch 40-47.

Teeth on premaxilla in 3 rows; teeth of inner row largest. Five tricuspidate teeth on outer row; outer row teeth arranged along margin of mouth and can be seen externally in closed mouth. Medial row with 3 tricuspidate teeth; inner row with 6 multicuspidate teeth. Maxilla with 2 flattened teeth, smaller than those on premaxilla. Teeth on lower jaw in 2 rows, outer row with 4 smaller teeth posteriorly and 4 larger teeth anteriorly. Inner row consisting of one conical symphyseal tooth.

Scales cycloid, thin, large. Lateral line distinctly decurved ventrally, completely pored from supracleithrum to base of caudal-fin rays. Thirty-two to 35 (mean $=33.8, \mathrm{n}=20)$ scales in lateral line; 5 scale series above lateral line; 2-3 scale rows below lateral line. Two scale rows between pectoral-fin insertion and midventral keel; 4-5 scale series on caudal peduncle. Nine to12 scales $($ mean $=10.2, \mathrm{n}=20)$ along mid-dorsal line from supraoccipital process to dorsal-fin origin.

Dorsal-fin rays ii,9; anal-fin rays iii-iv, 26-29 ( mean $=27.3$, $\mathrm{n}=24$ ); pectoral-fin rays i,10-12; pelvic-fin rays i, 6 . Dorsalfin base located on posterior one-half of body with last dorsal-fin ray located at vertical line through base of third or fourth anal-fin ray; first branched ray longest; following rays decreasing slightly in length. Pectoral fin pointed, tip reaching posteriorly to area middle and tip of pelvic fin. Anal-fin margin straight, first branched anal-fin ray longest; following rays gradually decreasing in length. Margin of caudal fin truncate; median rays extend about one-half their length beyond margin of remainder of fin. Scales covering basal one-third of fin.

Total vertebrae 37 .

Coloration in alcohol. Overall ground color yellowish silvery. Snout and dorsal portion of head dark. Scattered dark chromatophores present on opercle and infraorbitals 5 and 6. Body darker dorsally and dorsal to anal-fin base and on caudal peduncle. Five or 6 sinuous, brown, longitudinal stripes present on dorsolateral portion of body. Dark chromatophores distributed over all fins. Dorsal-fin rays outlined by dark chromatophores. Chromatophores distributed over pectoral-fin between the rays; more intense pigmentation present on first unbranched ray. Anal-fin margin darker. Middle caudal-fin rays very dark. 


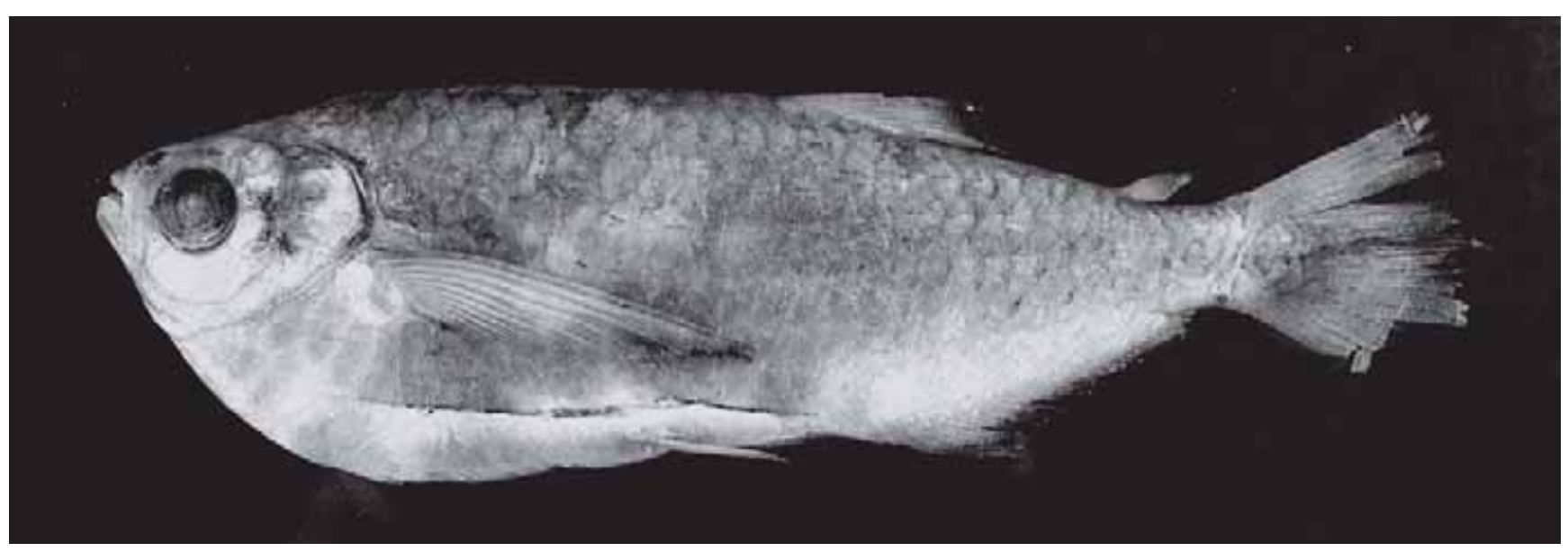

Fig. 10. Chalceus nematurus, lectotype, NMW 69034, 148.2 mm SL, Brazil, Mato Grosso, Cuiabá.

Distribution. Rio Tocantins and rio Araguaia drainages (Fig. 4).

Type-material remarks. The type material of Chalcinus trifurcatus consists of a dry specimen (MNHN A 9837). Measurements of the holotype presented in Table 7 are fairly accurate. They were obtained from a radiograph of that specimen.

Type-material examined. Chalcinus trifurcatus: holotype, MNHN A 9837, 136.29 mm SL, (dry specimen, only radiograph examined), Brazil, Pará, Araguaya, collected by Castelnau.

Non-type material. Brazil: Goiás: MZUSP 4832 (21 of 36), rio Araguaia, Aruanã $\left(14^{\circ} 53^{\prime} \mathrm{S}, 5^{\circ} 4^{\prime} \mathrm{W}\right)$. Tocantins: MZUSP 52122 (3), Araguaçu, rio Água Fria in the road between Araguaçu and Barreira do Piqui, $27 \mathrm{~km}$ North to Araguaçu $\left(12^{\circ} 43^{\prime} \mathrm{S}, 4^{\circ} 55^{\prime} \mathrm{W}\right)$. Mato Grosso: MZUSP 19633 (3), rio Araguaia, Santa Terezinha (10³5’S, 50³4'W). Pará: MZUSP 20640 (5), Tucuruí, rio Tocantins, below Tucuruí lake in the margin of igarapé Espírito Santo ( $\left.3^{\circ} 46^{\prime} \mathrm{S}, 49^{\circ} 41^{\prime} \mathrm{W}\right)$.

\section{Triportheus nematurus (Kner, 1858)}

Figs. 10 and 11

Chalcinus nematurus Kner, 1858:163. Kner, 1860:13-15 (more detailed description). Garman, 1890:3 (synonym of $C$. angulatus). Eigenmann \& Eigenmann, 1891:56 (synonym of Chalcinus angulatus). Ulrey, 1895:294 (synonym of Chalcinus angulatus). Ribeiro, 1941:162 (table with morphometrics).

Chalcinus paranensis Günther, 1874:454 (description, type locality: rio Paraná).

Triportheus paranensis. Fowler, 1950:358 (listed; rio Paraguay, rio Paraná). Portugal, 1990: 136-142. Britski et al., 1999:27. Reis et al., 2003:158.
Diagnosis. A deep bodied Triportheus species reaching 159 $\mathrm{mm}$ of SL (depth at dorsal-fin origin, 31.9-36.9, mean $=33.6 \%$ $\mathrm{SL}, \mathrm{n}=36$; depth at pectoral-fin insertion, 31.3-38.4, mean = $34.9 \% \mathrm{SL}, \mathrm{n}=36$ ). The presence of 2 longitudinal scale rows between the pectoral-fin insertion and ventral keel distinguish this species from elongate bodied Triportheus species that have 1 longitudinal scale row between the pectoral-fin insertion and the ventral keel. Among deep bodied Triportheus species, T. nematurus differs by the combination of the number of gill rakers on the lower limb of the first gill arch (38-48, mean $=42.7, \mathrm{n}=34)$; the number of lateral-line scales (33-37, mean $=34.2, \mathrm{n}=32$ ); the number of branched anal-fin rays $(25-31$, mean $=28.5, \mathrm{n}=35)$; and the presence of longitudinal dark stripes on the lateral surface of the body.

Description. Morphometric data for Triportheus nematurus presented in Table 8. Body deep and compressed laterally. Greatest body depth located slightly posterior to vertical through pectoral-fin insertion. Dorsal profile of head straight from snout to rear of head. Dorsal profile of body gently curved from rear of head to dorsal-fin origin; posteroventrally slanted from dorsal-fin origin to caudal peduncle; nearly straight along caudal peduncle.

Ventral profile of head straight from tip of lower lip to anteroventral margin of dentary; arched from that point to pelvic-fin insertion; nearly straight from pelvic-fin insertion to anal-fin origin; posterodorsally slanted along anal-fin base; straight along caudal peduncle. Prepelvic region very expanded ventrally and flattened, with well developed keel.

Head pointed in profile; posterior opercle margin almost reaching vertical through pectoral-fin insertion. Snout somewhat rounded anteriorly. Mouth terminal; lower jaw usually as long as upper jaw, but slightly longer in some specimens. Most specimens with very small barbel at each side of the mouth. Nostrils of each side close together; anterior opening circular; posterior elongate.

Gill rakers thin and close together, length equivalent to one-half of branchial filament length; gill rakers on lower portion of first gill arch 38-48 [47] $($ mean $=42.7, \mathrm{n}=34)$. 


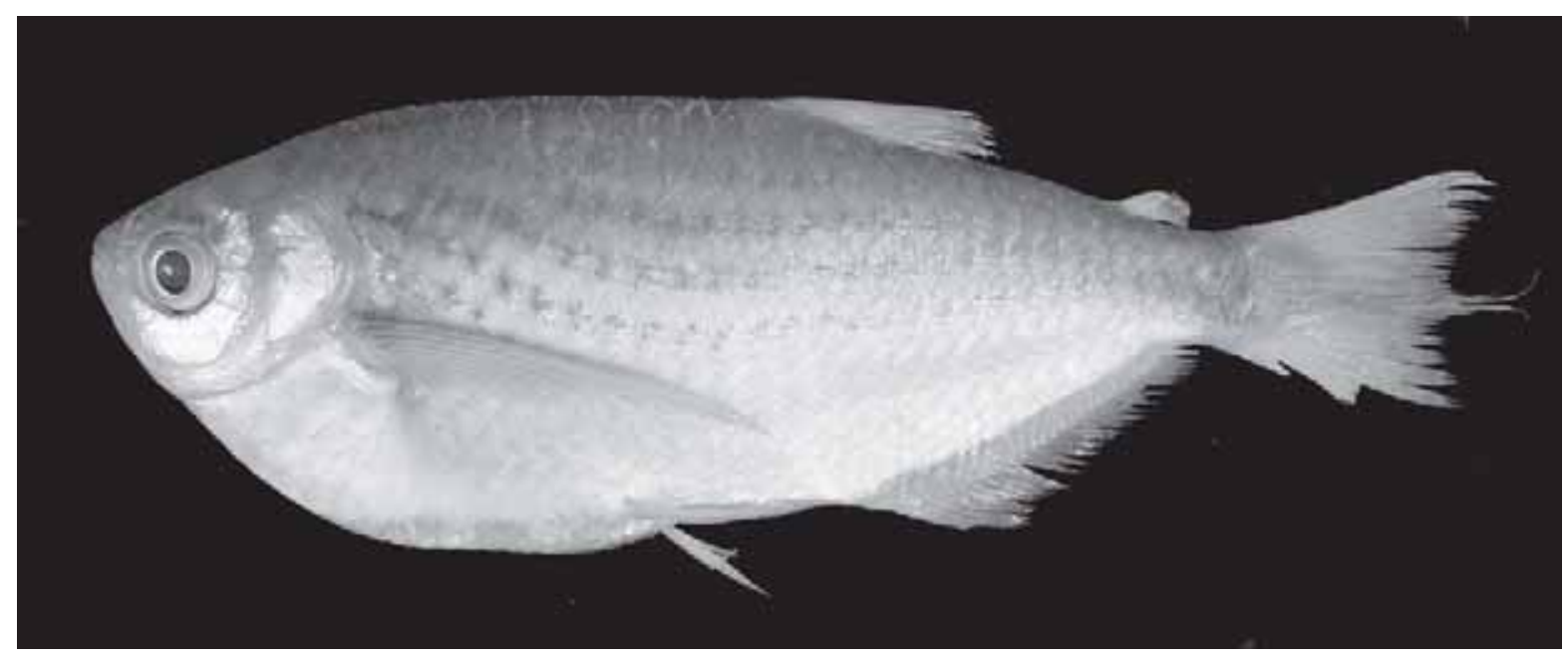

Fig. 11. Triportheus nematurus, NRM 50734, 135.81 mm SL, Paraguay, Presidente Hayes, río Paraguay.

Table 8. Morphometrics of Triportheus nematurus. Ranges include measurements of non-type specimens: MZUSP 85808 (28), USNM 326324 (1), USNM 181691 (3 of 4), USNM 181682 (3), USNM 181687 (1).

\begin{tabular}{lcccc}
\hline \multicolumn{1}{c}{ Character } & Lectotype & $\mathrm{N}$ & Range & Mean \\
\hline Standard length (mm) & 148.2 & 36 & $59.3-159.0$ & 113.9 \\
& Percents of standard length & \\
Bony head length & 23.9 & 36 & $22.9-28.0$ & 25.2 \\
Snout to anal-fin origin & 68.9 & 36 & $64.7-74.9$ & 69.6 \\
Snout to dorsal-fin origin & 58.2 & 35 & $56.1-61.6$ & 58.8 \\
Snout to pelvic-fin origin & 50.9 & 36 & $47.9-54.8$ & 51.6 \\
Anal-fin base length & 26.1 & 36 & $22.2-29.2$ & 26.1 \\
Caudal peduncle length & 7.1 & 36 & $6.8-10.7$ & 8.7 \\
Caudal peduncle depth & 8.9 & 36 & $8.2-9.8$ & 9.0 \\
Depth at dorsal-fin origin & 31.7 & 36 & $30.9-36.9$ & 33.6 \\
Depth at pectoral fin & 33.7 & 36 & $31.3-38.4$ & 34.9 \\
Dorsal-fin height & 17.6 & 36 & $17.6-22.3$ & 19.7 \\
Pelvic-fin length & 13.2 & 36 & $11.1-15.7$ & 13.5 \\
Pectoral-fin length & 35.1 & 35 & $35.5-40.0$ & 37.2 \\
& 21.9 & 35 & $19.9-25.8$ & 22.7 \\
Snout length & 22.6 & 36 & $19.2-27.9$ & 23.0 \\
Upper jaw length & 29.1 & 34 & $27.8-33.7$ & 30.6 \\
Horizontal eye diameter & 31.3 & 36 & $28.0-40.1$ & 34.1 \\
Least interorbital width & \multicolumn{4}{c}{ Percents of head length } \\
\hline
\end{tabular}

Teeth on premaxilla in 3 rows; teeth of inner row largest. Four to 5 tricuspidate teeth on outer row; outer row teeth arranged along margin of mouth and visible externally in closed mouth. Medial row with 3 tricuspidate teeth. Inner row with 6, rarely 7 , multicuspidate teeth. Maxilla with 0-2 flattened teeth smaller than those on premaxilla. Teeth on lower jaw in 2 rows; outer row with 4-5 larger anterior teeth, and 4-6 smaller posterior teeth. Inner row consisting of conical symphyseal tooth.

Scales cycloid, thin, large. Lateral line distinctly decurved ventrally, completely pored from supracleithrum to base of caudal-fin rays. Thirty-three to 37 [35] $($ mean $=34.2, \mathrm{n}=32)$ scales in lateral line; 6 scale series above lateral line; $1-2$ scale rows below lateral line. Two scale rows between pectoral-fin insertion and midventral keel; 5-6 scale series on caudal peduncle. Scales along mid-dorsal line very irregular; scales 7 13 [9] $($ mean $=9.5, \mathrm{n}=29)$ from tip of supraoccipital process to dorsal-fin origin.
Dorsal-fin rays ii,9; anal-fin rays iii,25-31 [28] ( $m e a n=28.5$, $\mathrm{n}=35$ ); pectoral-fin rays i,10-12; pelvic-fin rays i,6. Dorsal-fin margin straight; dorsal-fin base situated on posterior onehalf of the body; base of last dorsal-fin ray located at vertical through base of third or fourth anal-fin ray; first branched ray longest with following rays gradually decreasing in length. Pectoral fin pointed, tip reaching vertical through distal onethird of pelvic fin. Anal fin margin straight, first branched anal-fin ray longest; following rays gently decreasing in length. Margin of caudal fin truncate; median rays extend to varying degrees beyond margin of remainder of fin. Scales present over basal one-third of fin.

Total vertebrae 36-37 [37].

Coloration in alcohol. Overall ground color yellowish silvery. Snout and dorsal portion of head dark. Scattered dark chromatophores on opercle and infraorbitals 4-6. Body darker dorsally and on caudal peduncle. Five or 6 sinuous, brown, longitudinal stripes present along scale rows on dorsolateral portion of body. Dark chromatophores distributed over and between rays of all fins. Dorsal-fin rays outlined by dark chromatophores. Middle caudal-fin rays very dark.

Distribution. Río Paraguay and lower rio Paraná basins (Fig. 12).

Remarks. Two Triportheus species occur in the río La Plata drainage, including the rio Paraná and río Paraguay basins. These can be easily distinguished based on the number of lateral line scales and gill rakers. Two nominal species of Triportheus have been described for this drainage: $T$. nematurus (Kner, 1858) and T. paranensis (Günther, 1874). These names have been recently applied (Portugal, 1990; Britski et al., 1999; Reis et al., 2003) to the two Triportheus species recognized in the rio Paraná and rio Paraguay. Triportheus nematurus has been assigned to the form with lower counts of lateral line scales (28-32) and gill rakers (2633 ); while $T$. paranensis has been used for the form with higher counts (34-37 lateral line scales, 38-48 gill rakers). 


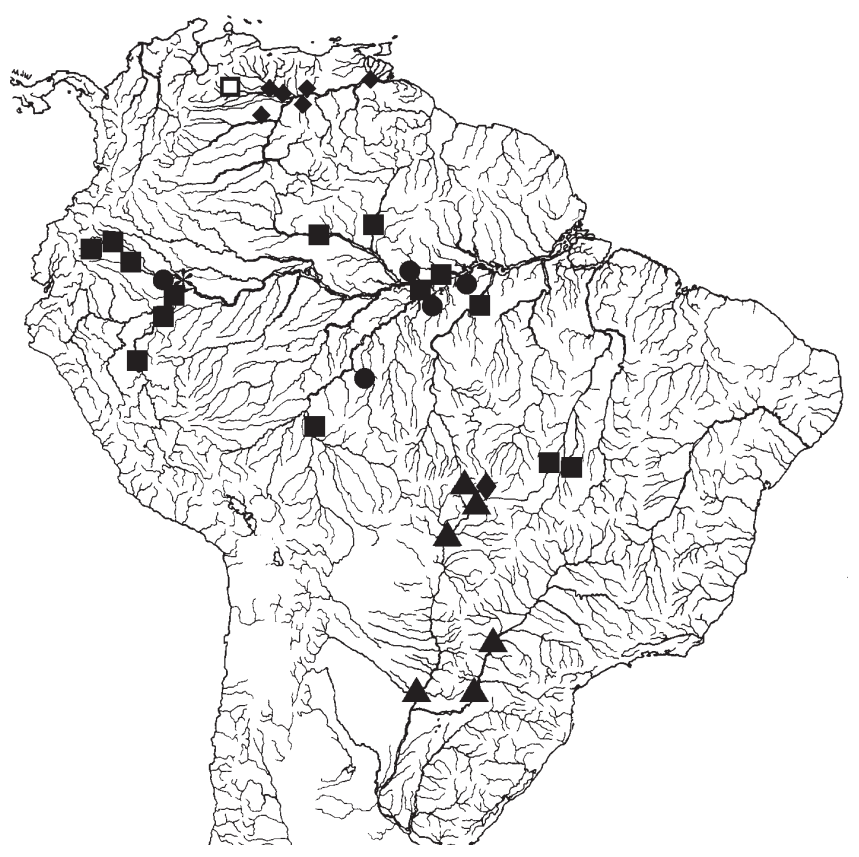

Fig. 12. Map of central and northern South America showing geographic distribution of $T$. culter (circles; asterisk = type-locality), T. albus (squares; asterisk = type-locality), T. nematurus (triangles; diamond = type-locality) and $T$. venezuelensis (lozenges; white square = type-locality) (some symbols represent more than one locality or lot of specimens).

The examination of the type-specimens of Chalcinus nematurus and $C$. paranensis, however, revealed that both nominal species are based on the form with higher lateral line and gill rakers counts. Since Chalcinus nematurus Kner, 1858 is the oldest available name, Chalcinus paranensis Fowler, 1950 becomes a junior synonym.

As a result, the species with higher lateral line and gill rakers counts referred to as T. paranensis by Portugal (1990), Britski et al. (1999) and Reis et al. (2003) is rather T. nematurus. This necessitates a new name for the species with lower lateral line and gill rakers counts erroneously referred by those authors as T. nematurus (see account of T. pantanensis).

Remarks about type-specimens. Syntypes of Chalcinus nematurus include 3 lots: NMW 69034(1), NMW 62694 (2) and NMW 62689 (2). The specimens of NMW 69034 and NMW 62694, have 35-36 lateral line scales, account that agrees with the 34-36 scales reported in the original description of $C$. nematurus (Kner, 1860). Lot NMW 69034 (1) is herein designated as the lectotype of $C$. nematurus and the specimens in the lot NMW 62694(2) become paralectotypes.

Type-material examined: Chalcinus nematurus: lectotype by present designation, NMW 69034 (1), 148.22 mm SL, Cujaba, Natterer. Paralectotypes: NMW 62694 (2, 143.91-168.67 mm SL), Cujaba, Natterer; NMW 16171 (1), dry specimen; NMW 62689 (2), 181-190 mm SL, Cujaba, Suaguragua, Caicara, J. Natterer .
Chalcinus paranensis, holotype, BMNH 1872.5.6:32 (1), 97.25 mm SL, rio Paraná.

Non-type material. Brazil: Mato Grosso: MZUSP 85808 (28), Ilha de Taiamã, rio Paraguay (10¹6'S, 5540'W). USNM 326324 (1), río Paraguay and tributaries around Cáceres (16² $\left.\mathrm{S}, 57^{\circ} 41^{\prime} \mathrm{W}\right)$. Paraguay: Presidente Hayes: NRM 50734(2), río Paraguay, (2450'4’S, 5746'0’'W); USNM 181691 (3 of 4); USNM 181682 (3); USNM 181687 (1), Baía Asuncion, río Paraguay, near Asuncion $\left(25^{\circ} 15^{\prime} \mathrm{N}, 57^{\circ} 40^{\prime} \mathrm{W}\right)$.

\section{Triportheus albus Cope, 1872 Fig. 13}

Triportheus albus Cope, 1872: 264 (type-locality: "from the Ambyiacu").

Chalcinus albus. Garman, 1890:6 (description, Chalcinus knerii Steindachner, 1876 as synonym). Fowler, 1906:447 (description; type-material listed). Jordan, 1919:363 (designation of "logotype"). Triportheus albus. Fowler, 1945:154 (listed; synonyms).

Chalcinus knerii Steindachner, 1876:50 (type not seen) typelocality: Tefé [rio Solimões].

Chalcinus rotundatus iquitensis Nakashima, 1941:65 (type locality: Porto de Iquitos).

Diagnosis. An elongate Triportheus species reaching 151 $\mathrm{mm} \mathrm{SL}$ (depth at dorsal-fin origin, 23.2-30.4, mean $=27.6 \%$ $\mathrm{SL}, \mathrm{n}=81$; depth at pectoral-fin insertion, 24.2-33.2, mean = $28.8 \% \mathrm{SL}, \mathrm{n}=79$ ). The presence of 1 longitudinal scale row between the pectoral-fin insertion and the ventral keel distinguishes this species from all deep-bodied Triportheus species all of which have 2 longitudinal scale rows between the pectoral-fin insertion and the ventral keel. The combination of the possession of 32-35 lateral line scales, 24-28 branched anal-fin rays, and 30-39 gill rakers on the lower limb of the first gill arch distinguish T. albus from elongatebodied congeners except T. brachipomus. T. albus is distinguished from T. brachipomus by the length of the postorbital region of the head (43.3-48.9\% of HL, mean $=45.8, \mathrm{n}=$ 30 versus $36.1-44.6 \%$ of $\mathrm{HL}$, mean $=39.9, \mathrm{n}=30$ in $T$. brachipomus), and the distance from the insertion of posterior most dorsal-fin ray to the adipose-fin origin (20.2-23.2\% of $\mathrm{SL}$, mean $=21.4, \mathrm{n}=30$ versus $14.5-21.2 \%$ of $\mathrm{SL}$, mean $=$ $17.4, \mathrm{n}=30$ in $T$. brachipomus)

Description. Morphometric data for Triportheus albus presented in Table 9. Body elongate and compressed laterally. Greatest body depth located slightly posterior to vertical through pectoral-fin insertion. Dorsal profile of head convex from upper lip to nares; nearly straight from nares to rear of head. Dorsal profile of body gently convex from rear of head to dorsal-fin origin; posteroventrally slanted along dorsal-fin base; straight from posterior terminus of dorsal-fin base to caudal peduncle; slightly concave along caudal peduncle. Dorsal portion of body transversely rounded. 


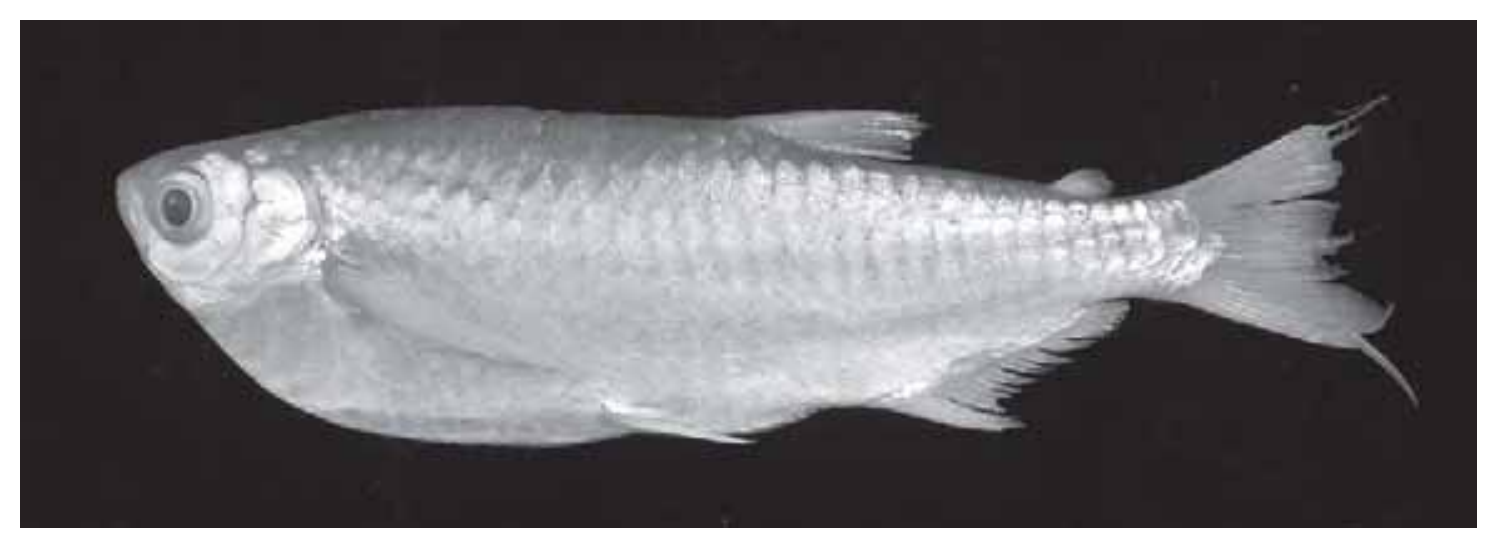

Fig. 13. Triportheus albus, MUSM 9676, 114.64 mm SL, Peru, Madre de Dios, río Madre de Dios, Tambopata.

Table 9. Morphometrics of Triportheus albus. Ranges include measurements of non-type specimens: FMNH 103053 (8), FMNH 94414 (3), FMNH 103052 (6 of 11), UMMZ 204248 (10), INHS66933 (11), INHS 65906 (7), MZUSP 30509 (5), MZUSP 5832 (10 of 14), MCP17210 (4 of 5), MCP 15160 (1), FMNH 56496 (8), INHS 38943 (8 of 9). Dashes indicate values that could not be taken as a consequence of damage to holotype.

\begin{tabular}{lcccc}
\hline \multicolumn{1}{c}{ Character } & Holotype & $\mathrm{N}$ & Range & Mean \\
\hline Standard length (mm) & 54.4 & 81 & $40.4-151.0$ & 95.5 \\
& Percents of standard length & & \\
Bony head length & 29.0 & 81 & $21.2-28.1$ & 23.5 \\
Snout to anal-fin origin & 69.4 & 81 & $67.4-77.0$ & 73.0 \\
Snout to dorsal-fin origin & 60.7 & 81 & $56.8-61.8$ & 59.1 \\
Snout to pelvic-fin origin & - & 81 & $49.0-56.1$ & 51.6 \\
Anal-fin base length & 22.0 & 81 & $19.7-25.6$ & 21.7 \\
Caudal peduncle length & 7.7 & 80 & $3.7-10.1$ & 7.1 \\
Caudal peduncle depth & 7.0 & 81 & $7.8-9.8$ & 8.6 \\
Depth at dorsal-fin origin & - & 81 & $23.2-30.4$ & 27.6 \\
Depth at pectoral fin & - & 79 & $24.2-33.2$ & 28.8 \\
Dorsal-fin height & - & 79 & $14.5-21.0$ & 17.3 \\
Pelvic-fin length & - & 81 & $9.9-16.5$ & 13.5 \\
Pectoral-fin length & - & 81 & $28.0-35.0$ & 32.1 \\
& Percents of head length & & \\
Snout length & 19.4 & 81 & $14.6-25.9$ & 21.1 \\
Upper jaw length & 21.9 & 80 & $18.5-29.4$ & 23.9 \\
Horizontal eye diameter & 30.7 & 81 & $22.8-33.9$ & 27.8 \\
Least interorbital width & 27.4 & 81 & $21.9-31.8$ & 27.2 \\
\hline
\end{tabular}

Ventral profile of head vertically straight from dorsal border of lower lip to anteroventral margin of dentary; very slightly convex from that point to isthmus. Ventral profile of body distinctly convex from isthmus to pelvic-fin insertion; nearly straight from that point to anal-fin origin; posterodorsally slanted along anal-fin base; slightly concave along caudal peduncle. Prepelvic region ventrally expanded with midventral keel.

Head obtusely pointed in profile; snout nearly straight in profile. Mouth terminal; lower jaw equal to upper jaw. Nostrils of each side close together; anterior opening circular; posterior kidney-shaped. Eye large, without adipose eyelid.

Gill rakers thin and close together; gill-rakers length about one-half of branchial filament length; gill rakers on lower limb of first gill arch 30-39 [32] ( mean =35.2, $\mathrm{n}=74)$.
Premaxilla with 2 irregular tooth rows. Outer row formed by 5 pentacuspidate teeth. Seven teeth on inner row; 2 medial teeth smaller than other teeth in series. Maxilla with 2-3 tricuspidate teeth all smaller than teeth on premaxilla. Teeth on lower jaw in 2 rows, with 6 teeth of 5-7 cusps on outer row; inner row consisting of conical symphyseal tooth.

Scales cycloid, thin, large. Lateral line distinctly decurved ventrally, completely pored from supracleithrum to base of caudal-fin rays. Thirty-two to 35 (mean $=33.6, \mathrm{n}=75$ ) scales in lateral line ( $50 \%$ of specimens with 34 scales); 5 scale series between lateral line and dorsal-fin origin; 1-2 scale rows from lateral line to pelvic-fin insertion. A series of large scales between pectoral-fin insertion and midventral keel; 9-14 (mean $=11.5, \mathrm{n}=68$ ) scales along mid-dorsal line between tip of supraoccipital process and dorsal-fin origin. Four or 5 rows of scales on caudal peduncle.

Dorsal-fin rays ii,9; anal-fin rays iii,24-28 [26] ( mean $=25.4$, $\mathrm{n}=78)$; pectoral-fin rays $\mathrm{i}, 10-13$ [10] ( mean $=11.1, \mathrm{n}=78)$; pelvic-fin rays i,6. Dorsal-fin margin straight, situated on posterior one-half of body; base of last dorsal-fin ray located anterior to vertical through anal-fin origin. Pectoral fin extending over proximal one-third of pelvic fin. Five most anterior branched anal-fin rays much longer than following rays. Caudal fin emarginate or forked; scaled only basally. Middle caudal-fin rays terminate at or slightly beyond posterior margin of remainder of fin.

Total vertebrae 38 [37].

Coloration in alcohol. Overall ground color yellowish brown. Body with diffuse, mid-lateral, silver stripe extending posteriorly from supracleithrum to caudal peduncle; stripe expanding vertically posteriorly. Body brownish dorsal to midlateral stripe; light yellow ventral to stripe. Pectoral fin dark pigmented along first rays. Dorsal and anal fin sparsely pigmented with dark chromatophores. Distal tips of anal-fin rays dark. Caudal-fin darkly outlined; series of chromatophores distributed on anterior one-third of caudal-fin rays.

Distribution. Rios Amazonas, Tocantins and Araguaia basins (Fig. 12). 
Type-material remarks. Cope (1872: 264) did not provide a catalog number for the type material of Triportheus albus, but only described it as "total length m..061; length to basis of dorsal fin .0292; from D.I to basis caudal .02" and refers to the type locality as "the Ambyiacu". Subsequently, Fowler (1906:447) listed the type as ANSP 21234. The holotype is a very damaged young specimen lacking the ventral margin of the body.

No type was designated for Chalcinus rotundatus iquitensis by Nakashima (1941) and the synonymy of that species into T. albus in this paper is based on information in the original description, in particular the 31 lateral line scales and $17+35$ gill rakers ("branquiespinas"). Chalcinus rotundatus iquitensis is an homonym of Chalcinus elongatus iquitensis Nakashima (1941:63) described in the same paper.

The types of Chalcinus knerii could not be located at NMW (H. Wellendorf pers. comm., Feb.1999). The single lot identified as Chalcinus knerii in that collection (NMW 1256263), is not labeled as type, and contains two specimens, instead of the one described by Steindachner. Although one of these specimens fits the length provided in the original description of $C$. knerii, it was collected in rio Negro, rather than "Amazonas (bei Teffe?)" as cited in the original description. Nonetheless, some data in the original description (lateral line scales 34 , anal-fin rays 29 , scale series above lateral line 5) suggests that $C$. knerii is a junior synonym of Triportheus albus.

Type- material. Triportheus albus, holotype, ANSP 21234, 54.4 mm SL, Peru, río Ambyiacu, J. Hauxwell.

Non-type material. Bolivia: Beni: UMMZ 204248 (10), río Itenez ( = rio Guaporé), opposite Costa Marques (12 $29^{\circ} \mathrm{S}$,

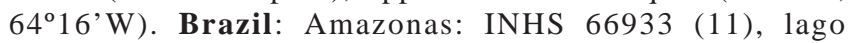
Marchantaria (4 $4^{\circ}$ 'S, 59 $9^{\circ}$ 'W); INHS 65906 (7) lake Terra Preta, about $8 \mathrm{~km} \mathrm{SW}$ Manaus (4ำ' $\left.12^{\prime} \mathrm{S}, 5^{\circ} 57^{\prime} \mathrm{W}\right)$; INHS 73035 (1 of 4),

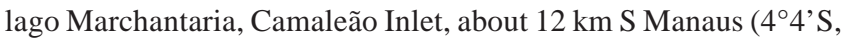
$59^{\circ} 7^{\prime} \mathrm{W}$ ); MZUSP 58853 (8), rio Negro, São Gabriel da Cachoeira $\left(0^{\circ} 7^{\prime} \mathrm{S}, 67^{\circ} 5^{\prime} \mathrm{W}\right)$; MZUSP 5852 (10 of 14), rio Negro, Manaus ( $\left.3^{\circ} 10^{\prime} \mathrm{S}, 60^{\circ} 0^{\prime} \mathrm{W}\right)$. Roraima: MZUSP 30509 (5), rio Branco, Marara ( $\left.1^{\circ} 2^{\prime} \mathrm{N}, 62^{\circ} 10^{\prime} \mathrm{W}\right)$. Goiás: MCP 17210 (4 of 5), lakes of rio Araguaia, near Luis Alves $\left(13^{\circ} 14^{\prime} \mathrm{S}, 50^{\circ} 35^{\prime} \mathrm{W}\right)$. Mato Grosso: MZUSP 53590 (4), rio Araguaia, furo near Aldeia Fontoura. Pará: MCP 15160 (1), rio Tapajós, in the Centro Educacional Boas Novas, Itaituba (4¹6’S, 5559’W); FMNH 56496 (8), Santarém (0`57'S, 4659'W). Ecuador: Napo: FMNH 103053 (8), río Napo at Destacamento Tiputini (047'S, 75³3'W); FMNH 94414 (3), río Napo, at Coca, beach in middle of river just upstream from bridge ( $\left.0^{\circ} 27^{\prime} \mathrm{S}, 7^{\circ} 54^{\prime} \mathrm{W}\right)$; FMNH 103052 (6 of 11), río Yasuni, laguna Jatuncocha ( $1^{\circ} 0$ 'S, $\left.75^{\circ} 29^{\prime} \mathrm{W}\right)$; FMNH 103054 (1), río Tiputini, near mouth in río Napo and Quebradas $\left(0^{\circ} 49^{\prime} \mathrm{S}\right.$, $75^{\circ} 31^{\prime}$ W). Peru: Loreto: INHS 38943 (8 of 9), Iquitos at Requena (034' 'S, 73¹4'W); INHS 43617 (1), río Napo and Quebradas. Madre de Dios: USNM 295169 (2), Parque Nacional Manu, Pakitza and vicinity ( $\left.7^{\circ} 16^{\prime} \mathrm{S}, 76^{\circ} 46^{\prime} \mathrm{W}\right)$; USNM 264028 (1), shore of island about $15 \mathrm{~km}$ downriver of junction of río Tambopata and río Madre de Dios (12³0’S, 698'W); MUSM 9676 (4), río Madre de Dios, Tambopata (12³0’49’S, 6847’44”W). Ucayali: USNM
280577 (1), Província Coronel Portillo, main channel and side pools of río Ucayali, $10 \mathrm{~km}$ upstream of Pucallpa ( $8^{\circ} 31^{\prime} \mathrm{S}$, $\left.74^{\circ} 22^{\prime} \mathrm{W}\right)$.

\section{Triportheus culter (Cope, 1872)}

Fig. 14

Chalcinus culter Cope, 1872:265 (description; type locality not mentioned).

Coscinoxyron culter. Fowler, 1907:450-451 (description; type species of the new genus Coscinoxyron). Eigenmann \& Allen, 1942:262 (designation as type species of the new genus Coscinoxyron).

Triportheus culter. Géry, 1977:343 (key; upper Amazon).

Chalcinus elongatus iquitensis Nakashima, 1941:64 (type not seen), Iquitos, Peru.

Diagnosis. An elongate Triportheus species reaching 245 $\mathrm{mm}$ SL (depth at dorsal-fin origin, 20.6-25.9, mean $=22.6 \%$ $\mathrm{SL}, \mathrm{n}=13$; depth at pectoral-fin insertion, 23.9-28.5, mean $=26.1 \% \mathrm{SL}, \mathrm{n}=13$ ). The presence of 1 longitudinal scale row between the pectoral-fin insertion and the midventral keel distinguish this species from all deep-bodied Triportheus species all of which that have 2 longitudinal scale rows between the pectoral-fin insertion and the ventral keel. The combination of the number of lateral-line scales $(43-47$, mean $=45.1, \mathrm{n}=12)$ and number of gill rakers on the lower limb of the first gill arch (53-83, mean $=70.7, \mathrm{n}$ = 13) distinguishes T. culter from all other elongate-bodied Triportheus species.

Description. Morphometric data for Triportheus culter presented in Table 10. Body elongate and compressed laterally. Greatest body depth located slightly posterior to vertical through pectoral fin insertion. Dorsal profile of head slightly convex from upper lip to nares; slightly slanted, nearly straight from nares to rear of head. Dorsal profile of body gently convex, almost straight from rear of head to dorsal-fin origin; posteroventrally slanted along dorsalfin base; less inclined from posterior terminus of dorsalfin base to caudal peduncle; slightly concave along caudal peduncle.

Ventral profile of head vertically straight from dorsal border of lower lip to anteroventral margin of dentary; straight from that point to isthmus. Ventral profile of body arched from isthmus to pelvic-fin insertion; slightly curved to nearly straight from that point to anal-fin origin; posterodorsally slanted along anal-fin base; slightly concave along caudal peduncle. Prepelvic region expanded, with midventral keel.

Head pointed in profile; snout straight, slightly blunted in profile. Mouth terminal; slightly upturned; lower jaw equal to upper jaw. Nostrils of each side close together; anterior opening circular; posterior kidney-shaped. Eye large, without adipose eyelid. 


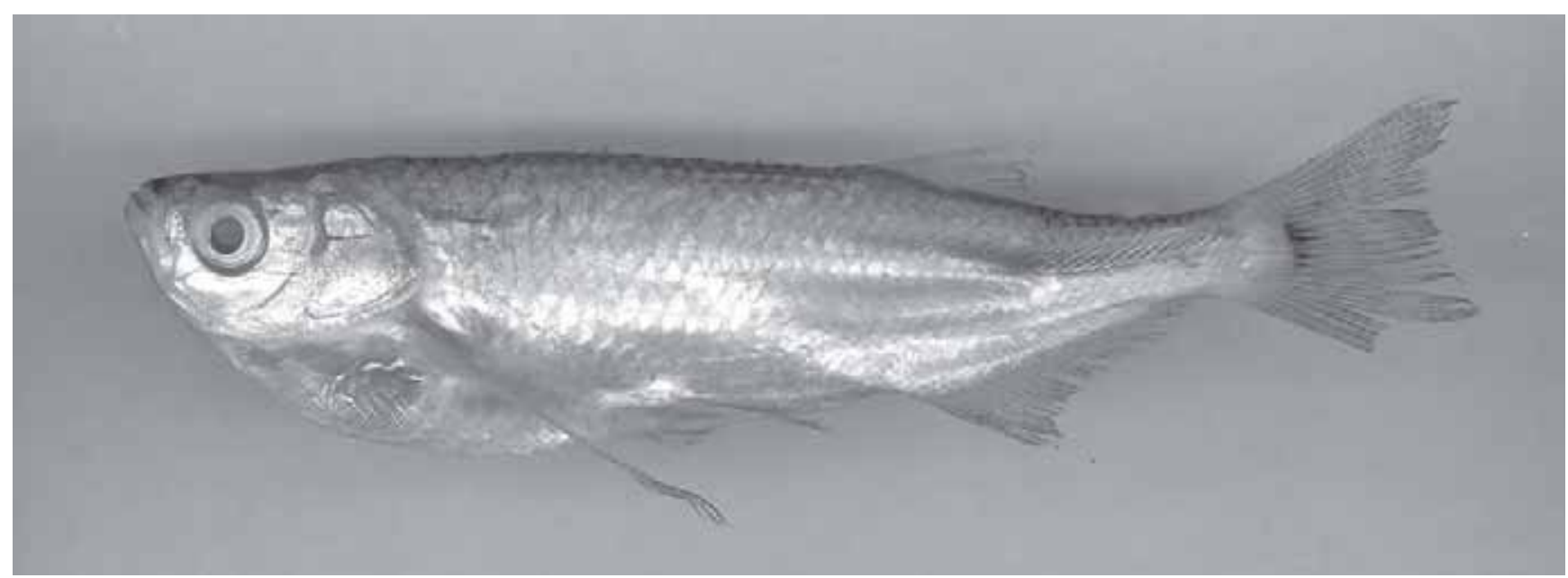

Fig. 14. Triportheus culter, INHS 43246, 100.62 mm SL, Peru, río Napo, 103 km NE Mazari.

Table 10. Morphometrics of Triportheus culter. Range includes measurements of non-type specimens: USNM 229129 (1), INHS 72547 (1), MZUSP 26438 (1), MZUSP 6068 (1), MZUSP 14047 (4), INHS 43246 (1), MUSM 12653 (2), MUSM 12683 (1), USNM 352932 (1 of 2). Dashes indicate values that could not be taken as a consequence of damage to holotype.

\begin{tabular}{lcccc}
\hline \multicolumn{1}{c}{ Character } & Holotype & $\mathrm{N}$ & Range & Mean \\
\hline Standard length (mm) & 130.5 & 13 & $100.6-245.0$ & 189.2 \\
& Percents of standard length & & \\
Bony head length & 26.43 & 13 & $23.0-26.6$ & 24.6 \\
Snout to anal-fin origin & 70.7 & 13 & $67.9-77.6$ & 71.3 \\
Snout to dorsal-fin origin & 65.2 & 13 & $63.2-70.2$ & 66.1 \\
Snout to pelvic-fin origin & 48.5 & 11 & $48.1-52.3$ & 49.9 \\
Anal-fin base length & 21 & 13 & $22.0-24.3$ & 23.0 \\
Caudal peduncle length & 7.24 & 13 & $4.7-9.1$ & 7.1 \\
Caudal peduncle depth & 6.68 & 13 & $7.0-8.2$ & 7.6 \\
Depth at dorsal-fin origin & - & 13 & $20.6-25.9$ & 22.6 \\
Depth at pectoral fin & - & 13 & $23.9-28.5$ & 26.1 \\
Dorsal-fin height & 14.3 & 12 & $9.4-14.7$ & 13.4 \\
Pelvic-fin length & 10.3 & 13 & $13.1-15.7$ & 14.2 \\
Pectoral-fin length & 34.6 & 13 & $32.2-37.8$ & 35.5 \\
& 22.1 & 13 & $18.6-25.2$ & 21.1 \\
Snout length & 17.6 & 13 & $16.4-20.7$ & 18.4 \\
Upper jaw length & 22.4 & 13 & $21.9-27.4$ & 23.8 \\
Horizontal eye diameter & 27.9 & 13 & $24.7-33.9$ & 28.8 \\
Least interorbital width & & & & \\
\hline
\end{tabular}

Opercle posteriorly expanded, its posterior margin reaching vertical through pectoral-fin insertion. Gill rakers thin and close together, gill-rakers as long as length of branchial filaments; gill rakers on lower limb of first gill arch 53-83 [62] (mean $=70.7, \mathrm{n}=13)$.

Teeth on premaxilla in two rows somewhat irregular giving appearance of 3 rows; teeth of inner row larger. Outer row formed by 6 pentacuspidate teeth. Six teeth on inner row; second tooth from symphysis smaller than other teeth in series. Maxilla with 2 teeth smaller than smallest premaxilla tooth. Teeth on lower jaw in two rows, with 5-6 teeth with 5-7 cusps on outer row; inner row consisting of 1 conical symphyseal tooth.
Scales cycloid, thin, large. Lateral line distinctly decurved ventrally, completely pored from supracleithrum to base of caudal-fin rays. Forty-three to 47 (mean $=45.1, \mathrm{n}=12$ ) scales in lateral line; 7 scale series between lateral line and dorsal-fin origin; 2 scale series between lateral line and pelvic-fin insertion. One large scale between pectoral-fin insertion and midventral keel; 18-22 scales along mid-dorsal line between tip of supraoccipital process and dorsal-fin origin. Four rows of scales on caudal peduncle.

Dorsal-fin rays ii,9; anal-fin rays iii,28-32 [32] (mean = 29, $\mathrm{n}=13$ ); pectoral-fin rays i,11-13 [12]; pelvic-fin rays i, 6 . Dorsal-fin base situated on posterior one-half of the body; base of last dorsal-fin ray located along vertical through first anal-fin ray. Pectoral fin long, reaching posteriorly to vertical through tip of pelvic fin. First branched anal-fin ray longest; following rays rapidly decreasing in length. Caudal fin emarginate, covered by scales only basally. Middle caudal-fin rays terminate at posterior margin of remainder of fin.

Total vertebrae 40 [40].

Coloration in alcohol. Overall ground color yellowish brown. Snout, lower lip, and dorsal portion of head dark. Scattered chromatophores present on all head bones. Body with dark mid-lateral stripe extending posteriorly from supracleithrum to caudal peduncle; stripe becoming diffuse posteriorly and broadened into distinctly wider diffuse dark spot on lateral surface of caudal peduncle. Body darker dorsal to midlateral stripe. All fins outlined by dark chromatophores. Caudal-fin rays outlined by series of chromatophores.

Distribution. Rio Amazonas basin (Fig. 12).

Type-material examined. Triportheus culter: holotype, ANSP 16672,130 mm SL, Peru, río Ampiyacu, John Hauxwell. 
Type-locality and type-material remarks. Cope (1872:265) did not furnish a catalog number for the type of Chalcinus culter and provided only the following information about that specimen: "Total length .158 m.; length to dorsal fin .087, to anal .098." The locality of collection is referred only in the introduction, in a general reference to the fishes listed in his paper. According to Cope the collection includes fishes from small tributaries of the río Ampiyacu, collected by John Hauxwell, and some additional species collected by Robert Perkins in an expedition from the mouth of rio Negro to the río Ucayali. The holotype and only specimen used by Cope was subsequently cited as ANSP 16672 by Fowler (1907:450) and Böhlke (1984:45). This specimen is cited as having been collected in Equador ( = Ecuador), by J. Hauxwell, in a locality that is now within Peru. It is a very damaged specimen but has 62 gill rakers (a count typical of $T$. culter).

No type was designated for Chalcinus elongatus iquitensis Nakashima, 1941. The synonym of the species into Triportheus culter herein is based on combination of characters presented in the description: number of lateral line scales (46) and gill rakers ("branquiespinas", 16+62).

Non-type material. Brazil: Amazonas: USNM 229129 (1), lago Terra Preta (412'S, 5957’ W); INHS 72547 (1), lago Terra Preta, Januari (4 ${ }^{\circ} 12^{\prime}$ S, 59 $\left.57^{\circ} \mathrm{W}\right)$; MZUSP 6068 (1), Manaus, rio Preto da Eva (36'S, 60 $\left.1^{\prime} \mathrm{W}\right)$; USNM 352932 (1 of 2), lago de Coari (48'S, 6320'W). Rondônia: MZUSP 14047 (4), rio Machado lago Jacundá ( $9^{\circ} 6^{\prime}$ S, $\left.62^{\circ} 48^{\prime} \mathrm{W}\right)$. Peru: Loreto: MZUSP 26438 (1), Supay-cocha (6 $\left.{ }^{\circ} 16^{\prime} \mathrm{S}, 74^{\circ} 48^{\prime} \mathrm{W}\right)$; INHS 43246 (1), río Napo, 103 km NE Mazari ( $\left.3^{\circ} 28^{\prime} \mathrm{S}, 72^{\circ} 45^{\prime} \mathrm{W}\right)$; MUSM 12653 (2), Maynas, rio Amazonas, Quistococha ( $\left.3^{\circ} 0^{\prime} \mathrm{S}, 7^{\circ} 39^{\prime} \mathrm{W}\right)$; MUSM 12683 (1), Maynas, rio Amazonas, Quistococha ( $\left.3^{\circ} 49^{\prime} \mathrm{S}, 73^{\circ} 16^{\prime} \mathrm{W}\right)$.

\section{Triportheus guentheri (Garman, 1890)} Fig. 15

Chalcinus güntheri Garman, 1890:4. (description, typelocality: rio São Francisco). Eigenmann, 1912:377 (as synonym of Chalcinus rotundatus).

Triportheus güntheri. Fowler, 1945:153-154 (listed).

Triportheus guentheri. Fowler, 1950:359 (synonym of $T$. rotundatus).

Chalcinus guentheri. Fowler, 1975:296 (synonym of Triportheus rotundatus).

Diagnosis. A deep-bodied Triportheus species reaching 133.7 $\mathrm{mm}$ of SL (depth at dorsal-fin origin, 28.2-37.0, mean $=33.4 \%$ $\mathrm{SL}, \mathrm{n}=26$ ); depth at pectoral-fin insertion, 29.3-34.9, mean = $32.2 \% \mathrm{SL}, \mathrm{n}=25$ ). The presence of 2 longitudinal scale rows between the pectoral-fin insertion and the ventral keel distinguish this species from Triportheus species with elongate bodies that have 1 longitudinal scale row between the pectoral-fin insertion and the ventral keel. Triportheus guentheri differs from all other deep-bodied congeners in the higher number of gill rakers on the lower limb of the first gill arch (5257 , mean $=54.8, \mathrm{n}=26$ ).
Description. Morphometric data for Triportheus guentheri presented in Table 11. Body deep and compressed laterally. Greatest body depth located slightly posterior to vertical through pectoral-fin insertion. Dorsal profile of head very slightly convex from snout to rear of head. Dorsal profile of body gently curved from rear of head to dorsal-fin origin; posteroventrally slanted and slightly convex from dorsalfin origin to caudal peduncle; slightly curved along caudal peduncle.

Ventral profile of head straight from tip of lower lip to anteroventral margin of dentary; slanted from that point to isthmus. Ventral profile of body arched from isthmus to pelvic-fin insertion; slightly convex from pelvic-fin insertion to anal-fin origin; posterodorsally slanted along anal-fin base; slightly curved along caudal peduncle. Prepelvic region very expanded ventrally and flattened, with well developed keel.

Head bluntly rounded in profile; posterior margin of opercle falling short of vertical through pectoral-fin insertion. Snout margin vertically straight. Mouth terminal; lower jaw as long as upper jaw. Nostrils of each side close together; anterior opening circular; posterior elongate. Gill rakers thin and close together, length equivalent to that of branchial filaments; gill rakers on lower limb of first arch 52$57[50]$ ( mean $=54.8, \mathrm{n}=26$ ).

Teeth on premaxilla in 3 rows; teeth of inner row largest. Four or 5 tricuspidate teeth in outer row; outer row teeth arranged along external margin of mouth and visible externally in closed mouth. Medial tooth row with 3 tricuspidate teeth. Six, rarely 7, multicuspidate teeth on inner row of premaxilla. Maxilla with 0-2 flattened teeth, smaller than those on premaxilla. Teeth on lower jaw in 2 rows. Outer row with 4-5 larger anterior teeth, followed by 4-6 smaller teeth. Inner row consisting of conical symphyseal tooth.

Scales cycloid, thin, large. Lateral line distinctly decurved ventrally, completely pored from supracleithrum to base of caudal-fin rays. Thirty to 33 (mean $=32.1, \mathrm{n}=20$ ) scales in lateral line; 5 scale series above lateral line; 2 scale rows between lateral line and pelvic-fin insertion. Two scale rows between pectoral-fin insertion and midventral keel; 4-5 scale series on caudal peduncle. Scale series along middorsal line irregular, 6-13 scales from supraoccipital process to dorsalfin origin.

Dorsal-fin rays ii,9; anal-fin rays iii,27-32 [29] $($ mean $=$ $30.5, \mathrm{n}=20$ ); pectoral-fin rays i,11-12 [10]; pelvic-fin rays i,6. Dorsal-fin base situated on posterior one-half of body; base of last dorsal-fin ray located anterior to vertical through anal-fin origin; first branched ray longest with following rays slightly decreasing in length. Pectoral fin pointed, tip reaching vertical through distal one-third of pelvic fin. Anal fin margin straight; first branched anal-fin ray longest; following rays gradually decreasing in length. Margin of caudal fin emarginate; median caudal-fin rays not extended beyond the posterior margin of fin. Scales cover basal onethird of fin.

Total vertebrae [37]. 


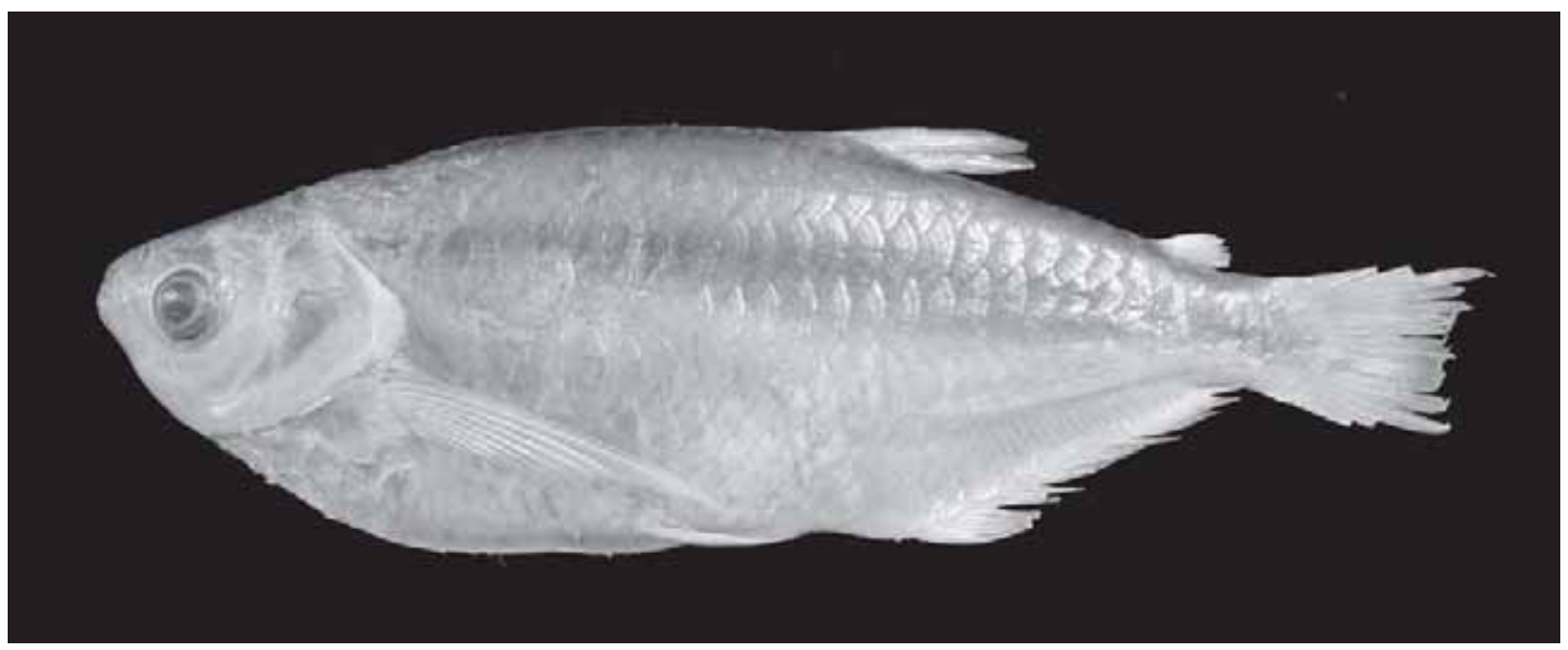

Fig. 15. Triportheus guentheri, MCP 14037, 133.7 mm SL, Brazil, Minas Gerais, rio São Francisco, Represa de Três Marias.

Table 11. Morphometrics of Triportheus guentheri. Ranges include measurements of non-type specimens: MZUSP 20436 (2), MZUSP 19663 (13 of 24), MCP 14037 (3 of 16), MCP 16710 (3 of 30), FMNH 56494 (5).

\begin{tabular}{lcccc}
\hline \multicolumn{1}{c}{ Character } & Holotype & $\mathrm{N}$ & Range & Mean \\
\hline Standard length $(\mathrm{mm})$ & 105.9 & 26 & $50.4-133.7$ & 95.8 \\
& Percents of standard length & & \\
Bony head length & 26.4 & 26 & $24.9-28.8$ & 26.5 \\
Snout to anal-fin origin & 69.4 & 26 & $65.7-71.6$ & 68.7 \\
Snout to dorsal-fin origin & 62.5 & 26 & $56.3-61.3$ & 59.8 \\
Snout to pelvic-fin origin & 49.1 & 24 & $48.2-52.3$ & 50.7 \\
Anal-fin base length & 28.9 & 26 & $23.8-30.7$ & 28.0 \\
Caudal peduncle length & 9.2 & 26 & $6.7-11.6$ & 8.5 \\
Caudal peduncle depth & 10.3 & 26 & $8.5-10.2$ & 9.6 \\
Depth at dorsal-fin origin & 36.7 & 25 & $28.2-37.0$ & 33.4 \\
Depth at pectoral fin & 35.4 & 25 & $29.3-34.9$ & 32.2 \\
Dorsal-fin height & 17.5 & 25 & $16.9-19.6$ & 18.2 \\
Pelvic-fin length & 9.24 & 25 & $10.0-14.4$ & 12.8 \\
Pectoral-fin length & 27.2 & 26 & $29.8-37.6$ & 33.9 \\
& 22.6 & 26 & $17.9-25.4$ & 22.2 \\
Snout length & 18.5 & 26 & $20.8-27.8$ & 24.4 \\
Upper jaw length & 23.9 & 26 & $24.0-33.9$ & 28.6 \\
Horizontal eye diameter & 31.9 & 26 & $26.9-32.6$ & 30.2 \\
Least interorbital width & & & &
\end{tabular}

Coloration in alcohol. Overall ground color yellowish with silver. Snout and dorsal portion of head darker. Scattered dark chromatophores located posterodorsal and posterior to orbit on infraorbitals 5 and 6 and opercle. Longitudinal dark stripe extends from supracleithrum to caudal peduncle. Stripe broadened into diffuse dark spot on lateral surface of caudal peduncle. Body darker above stripe. Dark chromatophores scattered over all fins. Caudal fin outlined by dark pigmentation.

Distribution. Rio São Francisco basin (Fig. 8).

Remarks. Garman (1890:4-5) stated that C. brachypomus Günther, 1864 "is so different in essential aspects from that of Valenciennes [C. brachipomus] that the two cannot be considered identical" and consequently that the material reported on by Günther (1864) represented a new species "Chalcinus güntheri”. Garman provided a brief diagnosis with counts of the dorsal, anal, and pelvic fins as well as the lateral-line scales (D. 11, A. 28, V. 7, L.1. 34), that seems to be a copy of the description of C. brachypomus by Günther (1864). In the description that follows this diagnosis, Garman, however, described a specimen ("Taking one from the San Francisco river as a typical specimen,...”) with counts different that those reported for C. brachypomus by Günther (1864) most notably the counts of anal-fin rays and lateral-line scales. The specimen discussed by Garman is then the holotype of Triportheus guentheri which differs from Chalcinus brachipomus Valenciennes, 1850. In the same paper, Garman (1890:3) considered, "C. brachipomus Val." to be synonym of $C$. angulatus and different from " $C$. brachypomus Günther". Later authors erroneously refer Chalcinus brachypomus as a junior synonym of Triportheus guentheri, following Garman (1890).

Günther (1864:341) presented a new spelling [brachypomus] for Chalcinus brachipomus Valenciennes, 1850, described from Mana, Essequibo River.

Type material. Chalcinus guentheri, holotype, MCZ 21173, 105.9 mm SL, Brazil, Minas Gerais, São Francisco river, 'below the falls" [probably near Pirapora, Brazil], F.C. Hartt, 1867 (Pirapora coordinates $\left.17^{\circ} 21^{\prime} \mathrm{S}, 44^{\circ} 56^{\prime} \mathrm{W}\right]$.

Type-material remarks. Garman (1890:1) cited his studied material as having been collected by the Thayer Expedition and deposited in the Museum of Comparative Zoology. Eschmeyer (1998:686) considered three uncatalogued BMNH specimens as syntypes of $C$. guentheri, which the type-locality as Essequibo and São Francisco based on the argument that Garman did not clearly designate a type. However, T. guentheri was based on one specimen (MCZ21173) from rio São Francisco ("Taking one from San Francisco river as a typical specimen") and as such the BMNH specimens are not syntypes. 


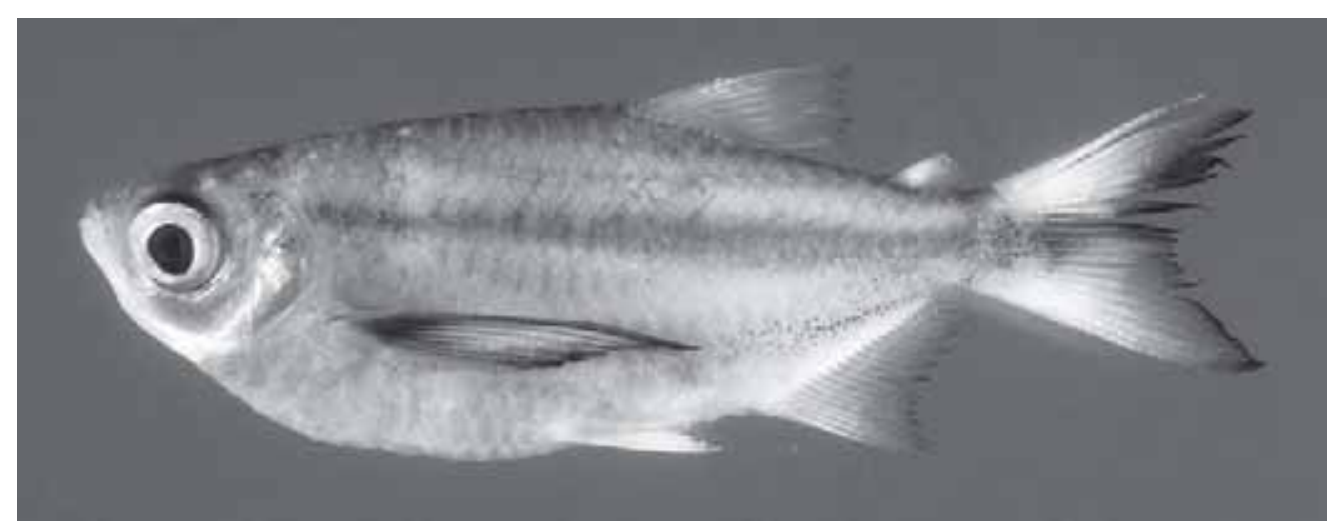

Fig. 16. Triportheus pictus, INHS 36731, 61.4 mm SL, Peru, Loreto, río Nanay, Amazonas drainage, Santa Clara, W of Iquitos.

Non-type material. Brazil: Bahia: MZUSP 20436 (2), Represa de Sobradinho (1260'S, 38 $59^{\prime} \mathrm{W}$ ); MCP 16710 (3 of 30), Bom Jesus da Lapa, riacho Santana, $31 \mathrm{~km}$ from Bom Jesus da Lapa

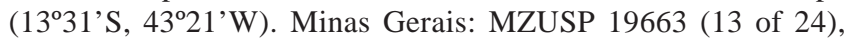
Represa de Três Marias (18 $40^{\circ} \mathrm{S}, 4^{\circ} 15^{\prime} \mathrm{W}$ ); MCP 14037 (3 of 16), rio São Francisco, Represa de Três Marias (18 $40^{\circ}$ 'S, $45^{\circ} 15^{\prime} \mathrm{W}$ ). Alagoas: FMNH 56494 (5), Penedo (10¹6'S, $\left.36^{\circ} 35^{\prime} \mathrm{W}\right)$.

\section{Triportheus pictus (Garman, 1890)}

Fig. 16

Chalcinus pictus Garman, 1890:5 (description, Brazil, Amazonas, rio Jutaí).

Triportheus pictus. Fowler, 1950:358 (listed, rio Jutahy)

Diagnosis. A deep bodied Triportheus species reaching 107.3 mm of SL (depth at dorsal-fin origin, 34.9-37.1\% SL; depth at pectoral-fin insertion, 35.4-36.6\% SL). The presence of 2 longitudinal scale rows between the pectoral-fin insertion and the ventral keel distinguish this species from elongated body Triportheus species that have 1 longitudinal scale row between the pectoral-fin insertion and the ventral keel. Triportheus pictus differs from all other deep bodied congeners in its lower number of gill rakers on the lower limb of the first gill arch $(22-24$, mean $=22.8, \mathrm{n}=4)$, and lower anal-fin ray count $(20-21$, mean $=20.5, \mathrm{n}=4)$.

Description. Morphometric data for Triportheus pictus presented in Table 12. Body very deep and compressed laterally. Greatest body depth located slightly posterior to vertical through pectoral-fin insertion. Dorsal profile of head straight from posterior border of premaxilla to rear of head. Dorsal profile of body very slightly convex, almost straight, from rear of head to dorsal-fin origin; posteroventrally slanted from dorsal-fin origin to caudal peduncle; straight along caudal peduncle.

Ventral profile of head somewhat anteriorly curved and then nearly straight to isthmus. Ventral profile of body arched from isthmus to pelvic-fin insertion; slightly curved from pel- vic-fin insertion to anal-fin origin; posterodorsally slanted along anal-fin base; straight along caudal peduncle. Prepelvic region ventrally expanded and flattened, with well developed keel.

Head pointed in profile; snout slightly blunted. Mouth terminal; lower jaw as long as upper jaw. Nostrils of each side close together; anterior opening circular; posterior elongate. Posterior margin of opercle falling short of pectoral-fin insertion.

Gill rakers thick and short, length equivalent to half of branchial filament length; gill rakers on lower limb of first $\operatorname{arch} 22-24$ [24] $($ mean $=22.8, \mathrm{n}=4)$.

Teeth on premaxilla in 2 rows; teeth of inner row largest. Five or 6 tricuspidate teeth on outer row and 6 multicuspidate teeth on inner row. Maxilla with 0 to 3 small, tricuspidate teeth. Teeth on lower jaw in 2 rows; outer row with 5 teeth with 5-7 cusps; teeth decreasing in size. Inner dentary tooth row consisting of one conical symphyseal tooth.

Scales cycloid, thin, large. Lateral line distinctly decurved ventrally, completely pored from supracleithrum to base of caudal-fin rays. Thirty to 32 scales in lateral line [32] (mean $=31, \mathrm{n}=4$ ); 5 to 6 scale series above lateral line; 2 scale rows below lateral line. Two scale rows between pectoral fin insertion and midventral keel; 5 scale series on caudal peduncle. Scales along mid-dorsal line 11-13 from supraoccipital process to dorsal-fin origin.

Dorsal-fin rays ii,9; anal-fin rays iii,20-21 [20] $($ mean $=$ 20.5, $\mathrm{n}=4$ ); pectoral-fin rays i,13-14 [13]; pelvic-fin rays i,6. Dorsal fin situated on posterior one-half of body; base of last dorsal-fin ray situated anterior to vertical through analfin origin. Dorsal fin margin straight; first branched ray longest. Pectoral fin pointed, tip reaching to vertical falling in region from middle to tip of pelvic fin. Anal-fin margin straight with first branched anal-fin ray longest and following rays gradually decreasing in length. Margin of caudal fin forked; median rays aligned, and not extending beyond margin of remainder of fin. Scales covering basal one-third of caudal fin.

Total vertebrae 36 [36]. 
Table 12. Morphometrics of Triportheus pictus. Range includes measurements of 4 non-type specimens: INHS 36731 (4).

\begin{tabular}{lccc}
\hline \multicolumn{1}{c}{ Character } & Holotype & Range & Mean \\
\hline Standard length (mm) & 107.3 & $54.7-61.4$ & 57.1 \\
& Percents of standard length & & \\
Bony head length & 24.2 & $27.7-29.1$ & 28.4 \\
Snout to anal-fin origin & 71.3 & $76.0-77.9$ & 77.0 \\
Snout to dorsal-fin origin & 59.2 & $59.9-61.8$ & 60.6 \\
Snout to pelvic-fin origin & 47.8 & $57.7-76.2$ & 62.6 \\
Anal-fin base length & 20.6 & $21.4-21.8$ & 21.6 \\
Caudal peduncle length & 9.4 & $5.4-6.0$ & 5.8 \\
Caudal peduncle depth & 9.8 & $9.6-10.3$ & 9.8 \\
Depth at dorsal-fin origin & 32.4 & $34.9-37.1$ & 36.1 \\
Depth at pectoral fin & 29.8 & $35.4-36.6$ & 36.0 \\
Dorsal-fin height & 22.5 & $20.5-23.0$ & 22.2 \\
Pelvic-fin length & 15.6 & $15.6-17.3$ & 16.5 \\
Pectoral-fin length & 37.6 & $39.6-41.3$ & 40.3 \\
& & \\
Snout length & 24.7 & $20.1-21.8$ & 21.0 \\
Upper jaw length & 24.7 & $25.2-28.8$ & 27.0 \\
Horizontal eye diameter & 34.8 & $33.8-35.8$ & 34.8 \\
Least interorbital width & 37.4 & $32.4-35.0$ & 33.9 \\
\hline
\end{tabular}

Coloration in alcohol. Overall ground color yellowish with silvery regions. Snout, dorsal portion of head and supraorbital regions dark. Some scattered dark chromatophores on opercle and infraorbitals 5 and 6. Longitudinal silver stripe extending from opercle to caudal peduncle. Body dorsal to stripe darkened by chromatophores concentrated in diffuse stripes.

Body darker on area above anal-fin base and on peduncle. Pectoral fins strongly pigmented along rays, with more intense pigmentation on first unbranched ray and along fin margin. Dorsal and anal fins slightly outlined by dark chromatophores. Some dark chromatophores outlining anal-fin rays. Caudal fin with diagonal dark stripe extending from caudal peduncle to posterior limit of dorsal caudal fin lobe.

Distribution. Rio Amazonas basin (Fig. 4).

Type-material remarks. In the original description of Chalcinus pictus Garman (1890:1) cited the material as originating from the Thayer Expedition and deposited in the $\mathrm{Mu}$ seum of Comparative Zoology but did not provide a catalog number for the holotype, referring only to "a specimen from Jutahy". One MCZ specimen labeled as Chalcinus pictus and collected by the Thayer expedition in the rio Hyutahy [Jutaí] (MCZ 21261) is considered to be the holotype. Features in this specimen (total length, head length, number of lateral line scales) agree with the information in the original description, in particular the very low number of anal-fin rays (20) typical of $T$. pictus. Higuchi (1996) cites complete data for the Thayer Expedition rio Jutahy site as: $2^{\circ} 43^{\prime} \mathrm{S}$, $66^{\circ} 57^{\prime}$ W, Sep-Oct 1865 , W. James, S. V. Thayer \& Talisman collectors.

Type-material examined. Chalcinus pictus: holotype. MCZ 21261 (107.34 SL), Brazil, Amazonas, rio Hyutahy, [rio Jutaí,
Solimões tributary, approx. $\left.2^{\circ} 43^{\prime} \mathrm{S}, 6^{\circ} 6^{\circ} 7^{\prime} \mathrm{W}\right]$ Sep 1865 , W. James, S. V. Thayer \& Talisman.

Non-type material. Peru: Loreto: INHS 36731 (4), río Nanay, Amazonas drainage, Santa Clara, W of Iquitos ( $\left.3^{\circ} 28^{\prime} \mathrm{S}, 73^{\circ} 5^{\prime} \mathrm{W}\right)$.

\section{Triportheus curtus (Garman, 1890)}

Fig. 17

Chalcinus angulatus curtus Garman, 1890:4 (diagnosis; described as subspecies of C. angulatus; type-locality: Brazil, "Pará and Arary").

Triportheus angulatus curtus. Fowler, 1940:101 (listed; Bolívia, Laguna Rogagua, Cachuela Esperanza, Rurrenabaque).

Triportheus curtus. Portugal, 1990:159-165 (description; synonymy list; illustration; map,).

Diagnosis. A deep-bodied Triportheus species reaching 106.8 $\mathrm{mm}$ of SL (depth at dorsal-fin origin, 33.5-36.2; depth at pectoral-fin insertion, 35.5-39.5\% SL). The presence of 2 longitudinal scale rows between the pectoral-fin insertion and the ventral keel distinguishes this species from elongate-bodied Triportheus species that have 1 longitudinal scale row between the pectoral-fin insertion and the ventral keel. Triportheus curtus differs from other deep-bodied Triportheus species by the combination of the number of gill rakers on the lower limb of the first gill arch $(23-28$, mean $=25.8, n=4)$; the number of lateral-line scales (32-34); the number of branched anal-fin rays $(24-28$, mean $=25.0, \mathrm{n}=4)$; the head length $(24.6$ 29.4 , mean $=28.4 \%$ of SL); the distance from the snout to the anal-fin origin $(74.5-75.9$, mean $=75.2 \%$ of SL); and the analfin base length $(23.1-24.5$, mean $=23.9 \%$ of SL).

Description. Morphometric data of Triportheus curtus presented in Table 13. Body very deep and compressed laterally. Greatest body depth located slightly posterior to vertical through pectoral-fin insertion. Dorsal profile of head straight from margin of premaxilla to rear of head. Dorsal profile of body very slightly convex, from rear of head to dorsal-fin origin; posteroventrally slanted from dorsal-fin origin to caudal peduncle; straight along caudal peduncle. Dorsal portion of body slightly keeled.

Ventral profile of head curved from tip of lower lip to isthmus. Ventral profile of body arched from isthmus to pelvic-fin insertion; slightly curved from pelvic-fin insertion to anal-fin origin; posterodorsally slanted along analfin base; straight along caudal peduncle. Prepelvic region very expanded ventrally and flattened, with well developed keel.

Head pointed in profile; snout slightly rounded. Mouth dorsally oriented; lower jaw equals to upper jaw. Nostrils of each side close together; anterior opening circular; posterior elongate. Posterior margin of opercle reaching to vertical through pectoral-fin insertion. 


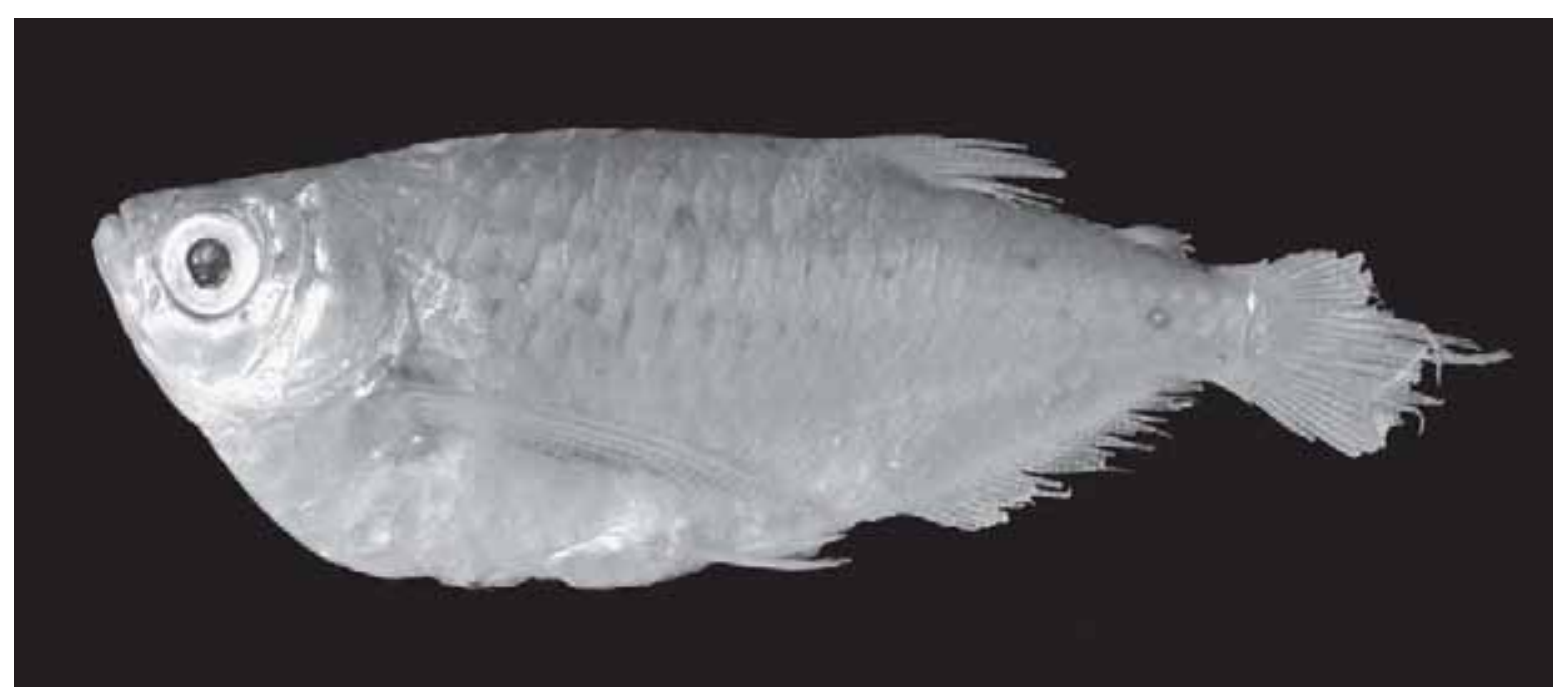

Fig. 17. Triportheus curtus, MUSM 6978, 51.12 mm SL, Peru, Ucayali, río Curanja, Cocha Grau.

Gill rakers thick and spaced, length equivalent to three quarters of branchial filament length; gill rakers on lower limb of first arch 23-28 [27-28].

Teeth on premaxilla in 2 rows; teeth of inner row larger. Outer row teeth irregularly arranged with 5 or 6 tricuspidate teeth. Six multicuspidate teeth on inner row in premaxilla. Maxilla with 0 to 3 small, tricuspidate teeth. Teeth on lower jaw in 2 rows, outer row with 5 teeth with 5-7 cusps, tooth size decreasing posteriorly. Inner dentary row consisting of conical, symphyseal tooth.

Scales cycloid, thin, large. Lateral line distinctly decurved ventrally, completely pored from supracleithrum to base of caudal-fin rays. Thirty-two to 34 scales in lateral line [32-34]; 5 scale series above lateral line; 2 scale rows below lateral line. Two scale rows between pectoralfin insertion and midventral keel; 5 scale series on caudal peduncle. Scales along mid-dorsal line very irregular, 613 [13-14] from supraoccipital process and to origin of dorsal fin.

Dorsal-fin rays ii,9; anal-fin rays iii,24-28 [26-28]; pectoral-fin rays i,11-13 [11]; pelvic-fin rays i,6. Dorsal fin situated on posterior one-half of body; base of last dorsal-fin ray located at vertical line running through base of fourth or fifth branched anal-fin ray; second unbranched and first branched ray longest; following rays gradually decreasing in length. Pectoral fin pointed, reaching vertical falling within area between middle and tip of pelvic fin. Anal-fin margin straight, first branched anal-fin ray longest; following rays gradually decreasing in length. Margin of caudal fin truncate; median rays extended beyond margin of remainder of fin. Scales cover basal one-third of fin.

Total vertebrae 36-37 [37].

Coloration in alcohol. Overall ground color yellowish with silver regions. Some small, dark spots scattered over body.

Distribution. Rio Amazonas basin (Fig. 8).
Type-material remarks. Garman (1890:1) cited the material that served as the basis of his description of Chalcinus angulatus curtus as being collected by the Thayer Expedition and deposited in MCZ. Garman did not list the type of his subspecies but 3 specimens identified as the syntypes of Chalcinus angulatus curtus (MCZ 21272 (2), MCZ 21264 (1)) are in the MCZ collections.

Type-material examined. Chalcinus angulatus curtus: syntype, MCZ 21272 (1 of 2), 70.9 mm SL, Brazil, Pará, lago Arari, Ilha de Marajó ( $0^{\circ} 20^{\prime}$ 'S, 49¹0' W), L. Agassiz, 1-5 Mar 1866. MCZ 21264 (1), syntype, $106.8 \mathrm{~mm}$ SL, J. Couto de Magalhães, 19-21 Aug 1865 [01 $\left.{ }^{\circ} 10^{\prime \prime} \mathrm{S}, 49^{\circ} 00^{\prime \prime} \mathrm{W}\right]$.

Non-type material. Peru: Ucayali: MUSM 6978 (4), Purus, río Curanja, Cocha Grau (0957’'S, 7059’ W).

Table 13. Morphometrics of Triportheus curtus. Ranges include measurements of 4 non-type specimens: MUSM 6978.

\begin{tabular}{lccc}
\hline \multirow{2}{*}{\multicolumn{1}{c}{ Character }} & Syntypes & \multicolumn{2}{c}{ Non-types } \\
\cline { 3 - 4 } & & Range & Mean \\
\hline Standard length (mm) & $70.9-106.8$ & $51.1-60.4$ & 55.7 \\
& Percents of standard length & & \\
Bony head length & $24.6-26.6$ & $27.9-29.4$ & 28.4 \\
Snout to anal-fin origin & $64.4-69.4$ & $74.5-75.9$ & 75.2 \\
Snout to dorsal-fin origin & $59.2-62.9$ & $61.9-64.1$ & 63.0 \\
Snout to pelvic-fin origin & $52.2-52.3$ & $57.9-60.7$ & 59.2 \\
Anal-fin base length & $22.4-29.3$ & $23.1-24.5$ & 23.9 \\
Caudal peduncle length & $96.3-10.0$ & $5.9-6.8$ & 6.3 \\
Caudal peduncle depth & $9.6-10.2$ & $8.0-9.2$ & 8.7 \\
Depth at dorsal-fin origin & $33.8-34.1$ & $33.5-36.2$ & 34.7 \\
Depth at pectoral fin & $35.5-35.7$ & $37.4-39.5$ & 38.7 \\
Dorsal-fin height & $19.5-20.1$ & $19.2-22.2$ & 20.5 \\
Pelvic-fin length & $14.9-16.4$ & $13.5-15.6$ & 14.6 \\
Pectoral-fin length & $38.4-39.5$ & $38.9-40.2$ & 39.7 \\
& Percents of head length & & \\
Snout length & $23.3-24.6$ & $18.9-20.9$ & 19.9 \\
Upper jaw length & $20.6-26.8$ & $21.9-23.3$ & 22.8 \\
Horizontal eye diameter & $29.2-29.5$ & $30.1-31.0$ & 30.6 \\
Least interorbital width & $36.1-39.3$ & $29.7-31.9$ & 31.0 \\
\hline
\end{tabular}




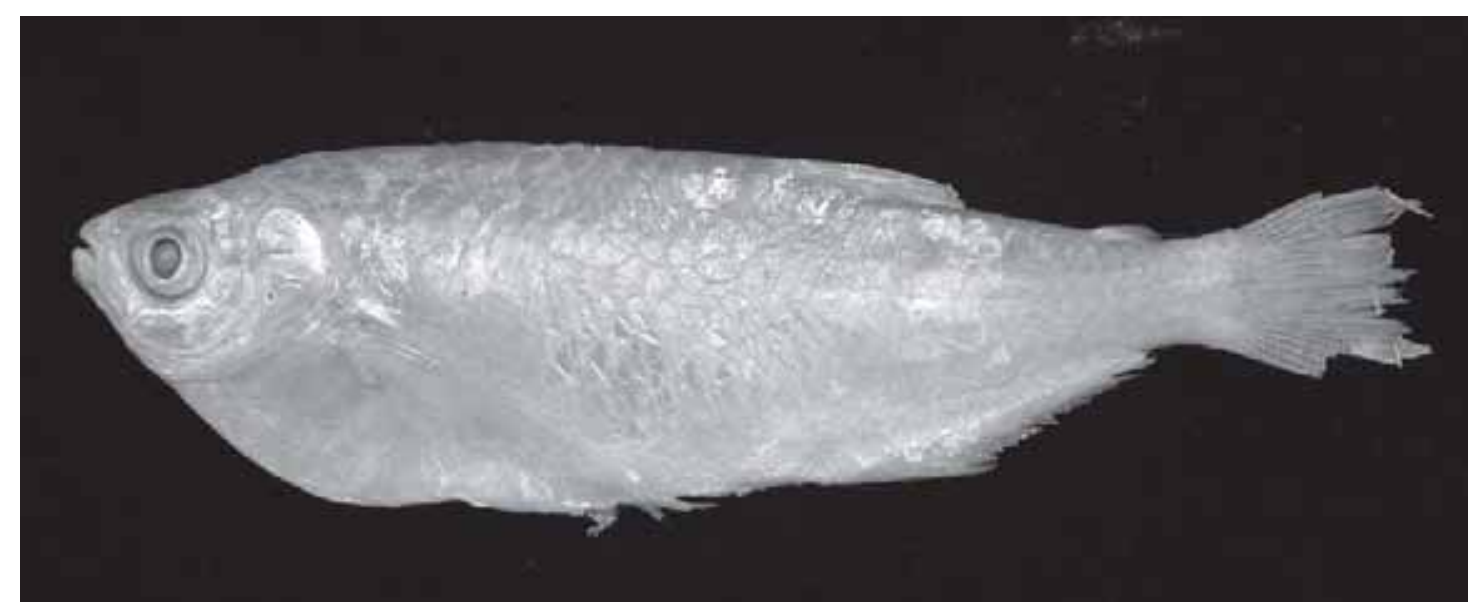

Fig. 18. Chalcinus angulatus signatus, syntype, MCZ 21267, 136.49 mm SL, Brazil, rio Poti.

Triportheus signatus (Garman, 1890)

Figs. 18 and 19

Chalcinus angulatus signatus Garman, 1890:4 (diagnosis; described as a variety of $C$. angulatus; type-locality: Brazil, "Rio Puty").

Triportheus angulatus signatus. Fowler, 1950:357 (synonymy; Brazil rio Itapicuru).

Triportheus signatus. Portugal, 1990:159-165 (redescription; synonymy list; illustration; map).

Diagnosis. A deep-bodied Triportheus species reaching 158.0 $\mathrm{mm}$ of SL (depth at dorsal-fin origin, 27.6-35.0 \% SL; depth at pectoral-fin insertion, 29.5-37.2\% SL). The presence of 2 longitudinal scale rows between pectoral-fin insertion and the ventral keel distinguishes this species from elongate-bodied Triportheus species that have 1 longitudinal scale row between pectoral-fin insertion and the ventral keel. Among deep bodied Triportheus species T. signatus can be distinguished by the combination of the number of gill rakers on the lower limb of the first gill arch $(35-44$, mean $=39.2, \mathrm{n}=32)$; the number of lateral-line scales (34-37, mean $=35.8, \mathrm{n}=29)$; and the presence of 6 scale series dorsal to the lateral-line series.

Description. Morphometric data for Triportheus signatus presented in Table 14. Body deep and compressed laterally. Greatest body depth located slightly posterior to vertical through pectoral-fin insertion. Dorsal profile of head straight from snout to rear of head. Dorsal profile of body gently curved from rear of head to dorsal-fin origin; posteroventrally slanted from dorsal-fin origin to caudal peduncle; gently curved along caudal peduncle.

Ventral profile of head straight from tip of lower lip to anteroventral margin of dentary; straight from that point to isthmus. Ventral body profile strongly arched from isthmus to pelvic-fin insertion; slightly convex from pelvic-fin insertion to analfin origin; posterodorsally slanted along the anal-fin base; nearly straight along the caudal peduncle. Prepelvic region very expanded ventrally and compressed, with well-developed keel.
Mouth slightly upturned, with lower jaw equals to upper jaw. Posterior margin of opercle almost reaching vertical through pectoral-fin insertion. Nostrils of each side close together; anterior opening circular; posterior elongate.

Gill rakers thin and close together, length equivalent to one-half of branchial filament length; gill rakers on lower limb of first arch 35-44 [37-43] ( mean = 39; $\mathrm{n}=33$ ).

Teeth on premaxilla in 3 rows; teeth of inner row largest. Five to 6 tricuspidate teeth on outer row; outer row teeth arranged along external margin of mouth and can be seen externally in closed mouth. Middle tooth row with 2-3 tricuspidate teeth. Inner row with 6 or 7 multicuspidate teeth. Maxilla with 1-3 teeth tricuspidate and much smaller than those on premaxilla. Teeth on lower jaw in two rows, outer row with 4-6 larger teeth, with 5-7 cusps, teeth decreasing in size posteriorly. Inner dentary row consisting of conical, symphyseal tooth.

Scales cycloid, thin, and large. Lateral line distinctly decurved ventrally, completely pored from supracleithrum to base of caudal-fin rays. Scales along lateral line 34-37 [35-37] $($ mean $=35.8 ; \mathrm{n}=33) ; 6$ scale series above lateral line; 2 scale rows below lateral line. Two scale rows between pectoral-fin insertion and midventral keel; 5 scale series on caudal peduncle. Scales along mid-dorsal line irregular, 9-14 scales from tip of supraoccipital spine to dorsal-fin origin.

Dorsal-fin rays ii, 9; anal-fin rays iii, 25-31 (mean $=28.6$; $\mathrm{n}=33$ ) [29-31]; pectoral-fin rays i, 10-13 [10-12]; pelvic-fin rays i, 6 . Dorsal-fin margin straight, situated on posterior one-half of body; base of last dorsal-fin ray located along vertical through base of first anal-fin ray; second unbranched and first branched dorsal-fin ray longest with following rays progressively decreasing in length. Pectoral-fin pointed, reaching up to vertical through middle of pelvic fin. Anal-fin margin straight, first branched anal-fin ray longest; following rays gradually decreasing in length. Margin of caudal fin truncate; median rays extended for one-third of their length beyond margin of remainder of fin. Basal one-third of caudal fin covered with scales.

Total vertebrae 37-38 [37-38] 


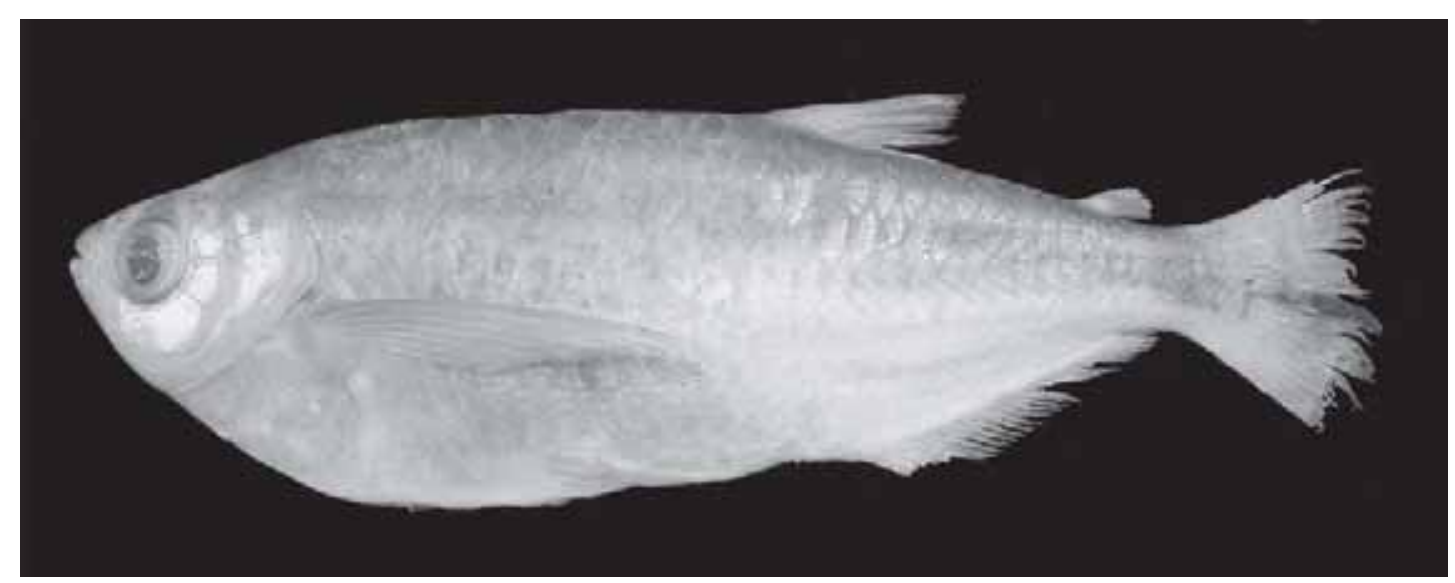

Fig. 19. Triportheus signatus, MCP 22682, $126.28 \mathrm{~mm}$ SL, Brazil, rio Parnaíba, Teresina on the road between Teresina and Palmerais.

Table 14. Morphometrics of Triportheus signatus. Ranges include measurements of 17 syntypes and non-type specimens: UMMZ 147372 (5), MCP 22063 (3), USNM 181973 (4), MZUSP 37581 (10), MZUSP 5105 (6), UMMZ $147364(5)$.

\begin{tabular}{|c|c|c|c|c|}
\hline \multirow{2}{*}{ Character } & \multirow{2}{*}{ Syntypes } & \multicolumn{3}{|c|}{ Non-types } \\
\hline & & $\mathrm{N}$ & Range & Mean \\
\hline Standard length (mm) & $92.6-147.1$ & 33 & $50.2-158.0$ & 108.5 \\
\hline \multicolumn{5}{|c|}{ Percents of standard length } \\
\hline Bony head length & $22.5-26.4$ & 33 & $22.5-27.7$ & 24.7 \\
\hline Snout to anal-fin origin & $63.2-70.7$ & 33 & $66.8-74.8$ & 70.6 \\
\hline Snout to dorsal-fin origin & $57.8-72.5$ & 33 & $58.3-69.2$ & 61.2 \\
\hline Snout to pelvic-fin origin & $46.0-67.0$ & 32 & $48.9-56.0$ & 52.7 \\
\hline Anal-fin base length & 24.4-29.9 & 32 & $24.4-29.8$ & 27.0 \\
\hline Caudal peduncle length & $7.6-10.8$ & 33 & $5.2-8.7$ & 6.8 \\
\hline Caudal peduncle depth & $8.2-9.2$ & 33 & $7.9-9.6$ & 8.9 \\
\hline Depth at dorsal-fin origin & $26.8-30.3$ & 33 & $27.6-35.0$ & 30.7 \\
\hline Depth at pectoral fin & $29.5-31.8$ & 33 & $30.0-37.2$ & 32.9 \\
\hline Dorsal-fin height & $16.8-19.4$ & 21 & $15.4-19.9$ & 17.6 \\
\hline Pelvic-fin length & $9.1-13.3$ & 24 & $9.4-14.0$ & 12.1 \\
\hline Pectoral-fin length & $31.5-36.5$ & 29 & $26.4-37.9$ & 32.4 \\
\hline \multicolumn{5}{|c|}{ Percents of head length } \\
\hline Snout length & $19.7-24.8$ & 33 & $19.7-24.1$ & 21.8 \\
\hline Upper jaw length & $20.4-29.7$ & 33 & $22.4-29.2$ & 25.1 \\
\hline Horizontal eye diameter & $24.7-30.5$ & 33 & $24.3-37.4$ & 28.4 \\
\hline Least interorbital width & $24.8-31.9$ & 33 & $25.2-33.4$ & 30.2 \\
\hline
\end{tabular}

Coloration in alcohol. Overall ground color yellowish. Snout and dorsal portion of head dark. Some scattered dark chromatophores on opercle and postorbital region. Body darker dorsally and over anal-fin base and peduncle. Three or four weak, dark longitudinal stripes present on dorsolateral portion of body. Dark chromatophores distributed over all fins. Scattered, dark chromatophores present on pectoral, dorsal, and anal fins. Middle caudalfin rays very dark.

Distribution. Rio Parnaíba basin and some Brazilian northeastern coastal drainages (Fig. 4).

Type-material remarks. Garman (1890:1) cites the material that served as the basis of the description of Chalcinus angulatus signatus as having been collected by the Thayer expedition and deposited in MCZ, but did not provide cata$\log$ numbers for the type-material. MCZ 21267 consists of 17 specimens labeled as syntypes of Chalcinus angulatus signatus.

Type-material examined. Chalcinus angulatus signatus: syntypes, MCZ21267 (17), 92.6-147.1 mm SL, Brazil, Piauí, rio Puty, Therezina [rio Poti, tributary rio Parnaíba, in Teresina] Dec 1865, O. St. John [Appr. 55'S, 42²4'W].

Non-type material. Brazil: Paraíba: UMMZ 147372 (5), açude Piranhas, Cajazeiras ( $\left.7^{\circ} 10^{\prime} \mathrm{S}, 38^{\circ} 28^{\prime} \mathrm{W}\right)$; USNM 181973 (4), açude Piranhas ( $\left.7^{\circ} 10^{\prime} \mathrm{S}, 38^{\circ} 28^{\prime} \mathrm{W}\right)$. Maranhão: MZUSP 19359 (2) rio Mearim ( $\left.3^{\circ} 4^{\prime} \mathrm{S}, 4^{\circ} 34^{\prime} \mathrm{W}\right)$. MZUSP 19571 (4), rio

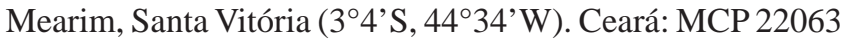
(3), rio Turiaçu, Araguana (6³5'S, 4840'W). MZUSP 37581 (10), Aiuaba, riacho do Umbuzeiro ( $6^{\circ} 33^{\prime} \mathrm{S}, 40^{\circ} 0$ ' $\left.\mathrm{W}\right)$; UMMZ 147364 (5), Icó, rio Salgado (6¹9’S, 3841'). Piauí: MCP 22682 (1), Brazil, rio Parnaíba, Teresina on the road Teresina-

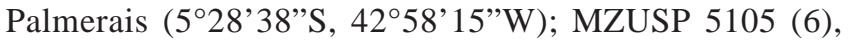
Teresina, rio Paraíba ( $\left.5^{\circ} 4^{\prime} \mathrm{S}, 42^{\circ} 48^{\prime} \mathrm{W}\right)$.

\section{Triportheus magdalenae (Steindachner, 1878)}

Figs. 20 and 21

Chalcinus magdalenae Steindachner, 1878:88, 91 (diagnosis; type-locality:"Magdalenen-stromes" [Colombia, Río Magdalena]). Steindachner, 1879: 20, 60-61 (detailed description; Pl. 11, figs. 1-2: male, female, dentition).

Triportheus magdalenae. Miles, 1947:163-164

Diagnosis. An elongate Triportheus species reaching 199 $\mathrm{mm} \mathrm{SL}$ (depth at dorsal-fin origin, 22.4-29.1\% SL, $\mathrm{n}=51$; depth at pectoral-fin insertion, 25.7-32.5, $\mathrm{n}=51$ ). The presence of 1 longitudinal scale row between the pectoral-fin insertion and the ventral keel distinguishes this species from deepbodied Triportheus species that have 2 longitudinal 


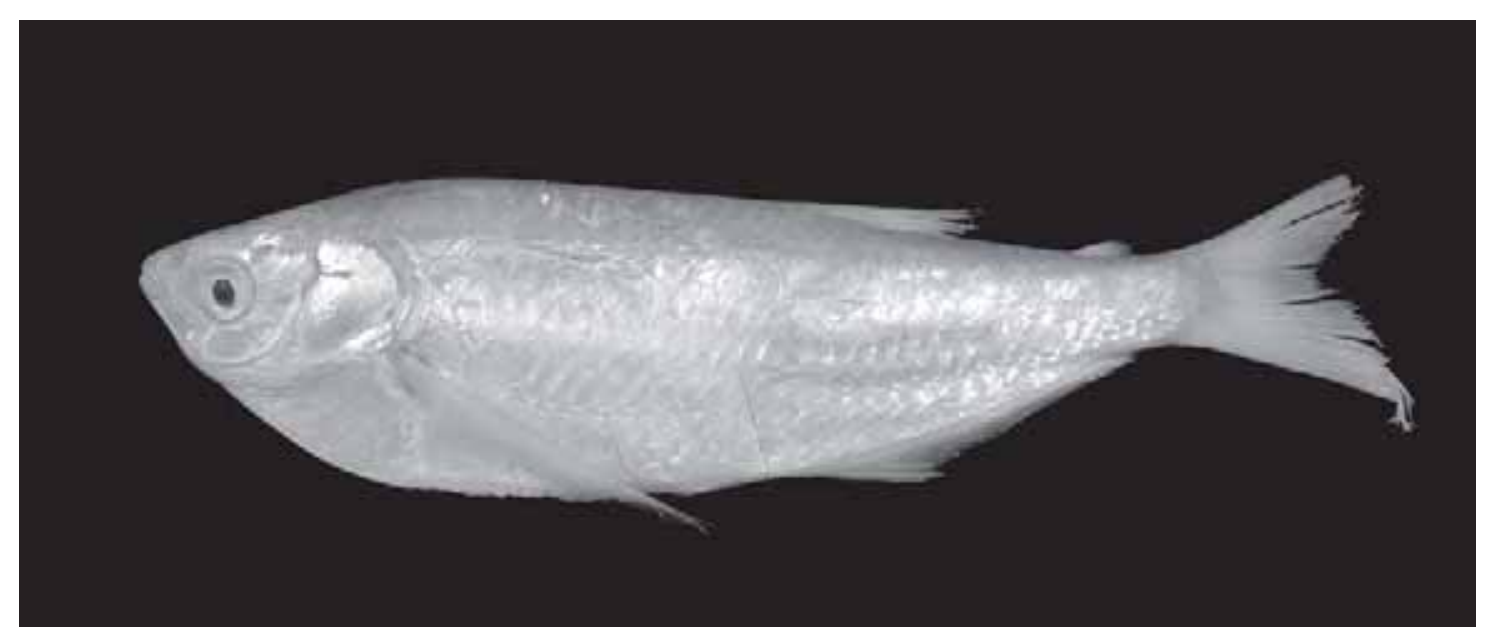

Fig. 20. Triportheus magdalenae, MZUSP 42201, 151.58 mm, Colombia, Antioquia, río Cauca, Caucasia.

scale rows between the pectoral-fin insertion and the ventral keel. This species can be further distinguished from all other Triportheus species by the high number of anal-fin rays (32-39).

Description. Morphometric data of Triportheus magdalenae presented in Table 15. Body elongate, distinctly compressed laterally. Greatest body depth located slightly posterior to vertical through pectoral-fin insertion. Dorsal profile of head nearly straight from margin of snout tip to rear of head. Dorsal profile of body in females convex from rear of head to dorsal-fin origin; posteriorly slanted from that point to caudal peduncle. Dorsal profile less convex in males from rear of head to dorsal-fin origin. Ventral profile of body distinctly arched from lower jaw tip to anal-fin origin; straight and posterodorsally slanted along base of anal fin; slightly concave along caudal peduncle. Prepelvic region between isthmus to pelvic-fin insertion distinctly expanded ventrally, with well-developed midventral keel.

Head obtusely pointed in profile; with posterior margin of the opercle reaching vertical through pectoral-fin insertion. Mouth terminal; lower jaw as long as upper. Gill rakers on lower limb of first arch 33-90 [73-87] (mean =70.5, $\mathrm{n}=49)$; 5090 in specimens over $60 \mathrm{~mm}$ SL (see Remarks).

Two rows of teeth on premaxilla; teeth of inner row larger. Inner tooth row with 7 tricuspidate to pentacuspidate teeth. Outer row with 5 teeth. Maxilla with 0 to 2 teeth smaller than smallest teeth on premaxilla. Dentary with 2 tooth rows; outer row with 7-8 teeth, decreasing in size posteriorly; dentary teeth with 3-5 cusps; inner row consisting of conical symphyseal tooth.

Scales cycloid, thin, and large. Lateral line distinctly decurved ventrally, completely pored from supracleithrum to base of caudal-fin rays. Thirty-eight to 42 scales in lateral line [38-39] $($ mean $=39.1, \mathrm{n}=47$ ); 6-7 scale series between the lateral line and dorsal fin origin; 2 scale rows from lateral line to pelvic-fin insertion. A large scale present between pectoral-fin insertion and midventral keel; 11-17 [14-17] $($ mean = $14.1, \mathrm{n}=26$ ) scales along mid-dorsal line between tip of su- praoccipital process and origin of dorsal fin. Four to 6 [4-5] rows of scales on caudal peduncle.

Dorsal-fin rays ii,9; anal-fin rays iii,32-39 [34-38]; pectoralfin rays i,10-12 [10-11]; pelvic fin rays i,6. Dorsal-fin base situated on posterior one-half of body; base of last dorsal-fin ray located anterior to vertical through anal-fin origin. Pectoral fin large, reaching vertical through tip of pelvic fin. First branched anal-fin ray longest; following rays rapidly decreasing in length. Caudal fin forked, lobes obtusely pointed; scaled only at base.

Total vertebrae 39-40 [39-40].

Color in alcohol. Overall color of specimens preserved in alcohol silvery yellow. Outline of posterior margin of caudal fin dark.

Remarks. Triportheus magdalenae is the only member of the genus known from the río Magdalena drainage, Colombia. This species demonstrate a large degree of variation in body shape, length of the anal-fin base, and the number of gill rakers. The variation in body shape is apparently associated with sexual dimorphism. Male specimens have a more elongate body (body knife-shape) than females (body fusiform). However, only a few specimens could be dissected to confirm this observation and further analysis is necessary. Nonetheless the variation in body shape does not reveal any patterns that would justify the recognition of more than one species. Although the high number of gill rakers is distinctive for T. magdalenae, this number varies increasing ontogenetically, as shown in Figure 22.

Distribution. Río Magdalena basin (Fig. 23).

Type-material examined. Chalcinus magdalenae: syntypes, NMW 69151 (7), 141-199 mm SL, Colombia, Magdalena Strom (= río Magdalena), 31 Sep 1876; NMW 69152 (2), syntypes, 153191 mm SL, Magdalena Strom, Colombia; 31 Nov 1876. NMW 69153 (4), syntypes, 155-192 mm SL, Magdalena Strom, Cienaga [11.01 $\left.{ }^{\circ} \mathrm{N} 74.26^{\circ} \mathrm{W}\right]$, Colombia; 1876. NMW 69154 (2), syntypes, 137 mm SL, Magdalena Strom, Colombia; 31 Nov 1876. 


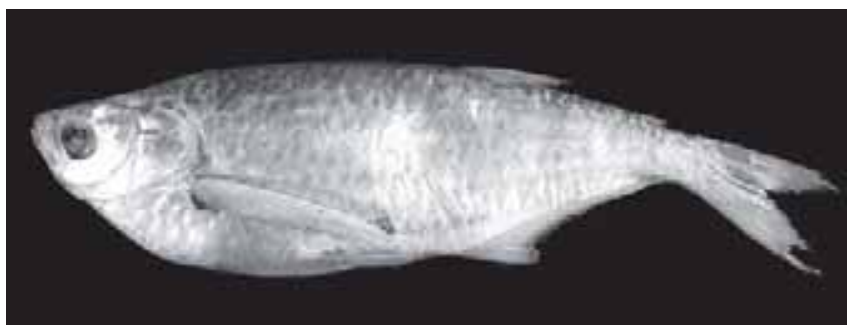

Fig. 21. Chalcinus magdalenae, syntype, NMW 69152, 191 mm SL, Colombia, Magdalena, Río Magdalena.

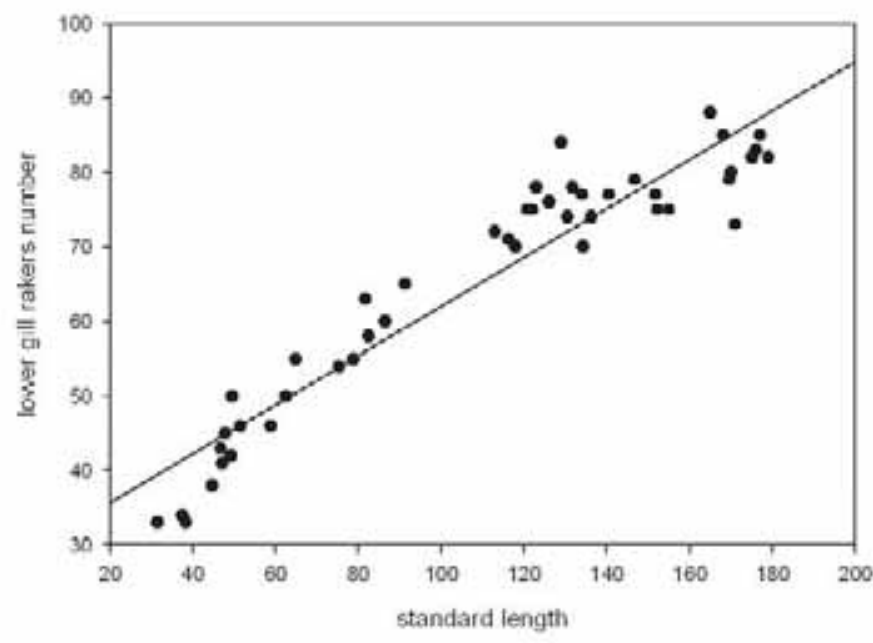

Fig. 22. Linear regression of gill rakers count versus standard length for Triportheus magdalenae $(\mathrm{n}=47 ; 31-180 \mathrm{~mm} \mathrm{SL})$.

Table 15. Morphometrics of Triportheus magdalenae. Ranges include measurements of 15 syntypes and 44 non-type specimens: FMNH 56321 (5 of 9), FMNH 56324 (10), FMNH 56327 (5), FMNH 56328 (4 of 8), FMNH 69628 (7 of 149), FMNH 69756 (10 of 91), FMNH 88185 (6 of 16), MZUSP 42201 (2), USNM 079182 (3), USNM 116460 (1), USNM 167797 (2), USNM 175327 (6).

\begin{tabular}{lcccc}
\hline \multirow{2}{*}{ Character } & \multirow{2}{*}{ Syntypes } & \multicolumn{3}{c}{ Non-types } \\
\cline { 3 - 5 } & & $\mathrm{N}$ & Range & Mean \\
\hline Standard length (mm) & $137.0-199.0$ & 44 & $47.8-189.0$ & 126.0 \\
& Percents of standard length & & \\
Bony head length & $24.6-29.9$ & 44 & $22.7-27.3$ & 25.5 \\
Snout to anal-fin origin & $63.1-77.4$ & 44 & $57.7-67.2$ & 63.4 \\
Snout to dorsal-fin origin & $60.8-73.4$ & 44 & $59.7-66.9$ & 61.9 \\
Snout to pelvic-fin origin & $45.6-55.7$ & 44 & $42.4-50.1$ & 46.8 \\
Anal-fin base length & $29.2-35.8$ & 44 & $26.6-31.7$ & 29.2 \\
Caudal peduncle length & $10.5-13.8$ & 44 & $7.6-11.5$ & 10.0 \\
Caudal peduncle depth & $7.0-9.2$ & 44 & $6.7-8.6$ & 7.9 \\
Depth at dorsal-fin origin & $22.4-29.0$ & 44 & $24.4-29.1$ & 26.4 \\
Depth at pectoral fin & $25.7-32.5$ & 44 & $25.9-30.6$ & 28.1 \\
Dorsal-fin height & $14.6-16.2$ & 44 & $13.8-19.6$ & 15.8 \\
Pelvic-fin length & $8.8-13.3$ & 44 & $9.7-13.5$ & 12.2 \\
Pectoral-fin length & $30.9-38.0$ & 44 & $30.2-34.9$ & 32.6 \\
& $19.3-22.7$ & 44 & $14.8-23.1$ & 19.5 \\
Snout length & $20.3-23.3$ & 44 & $20.7-26.7$ & 23.1 \\
Upper jaw length & $18.9-22.8$ & 44 & $20.0-44.2$ & 24.6 \\
Horizontal eye diameter & $18.7-23.5$ & 44 & $17.8-25.2$ & 22.0 \\
Least interorbital width & & & &
\end{tabular}

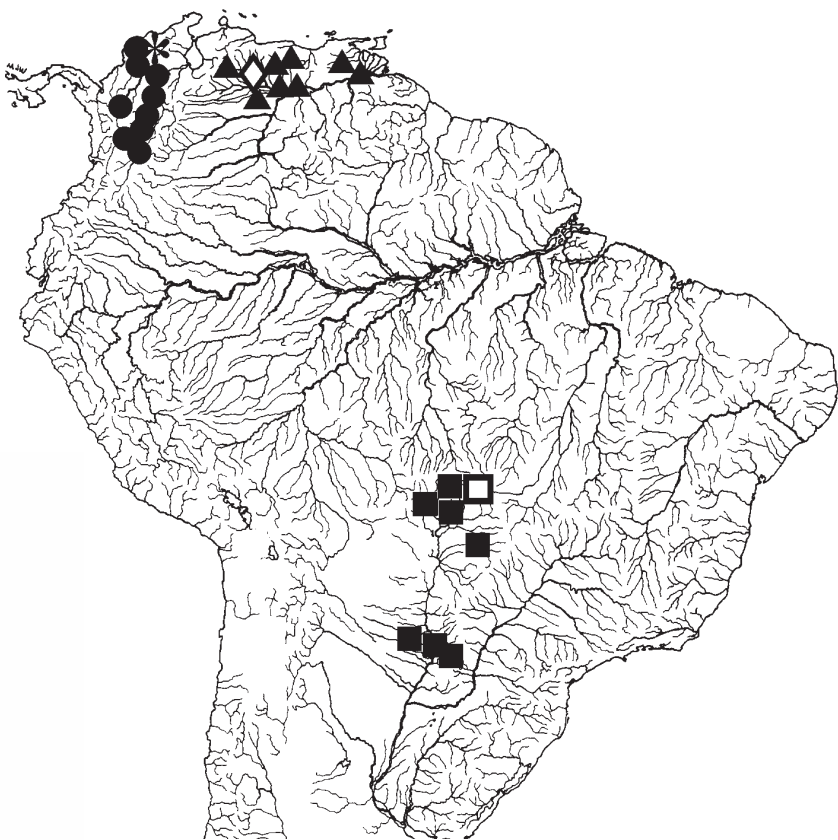

Fig. 23. Map of central and northern South America showing geographic distribution of Triportheus magdalenae (circles; asterisk = type locality), . pantanensis (black squares; white square = type locality) and T. orinocensis n. sp. (triangles; white diamond = type locality) (some symbols represent more than one locality or lot of specimens).

Type-material remarks. In the original description of Chalcinus magdalenae, Steindachner (1878) did not provide information on the specimens that were the basis of the description nor note a specific type locality, only providing a general locality of "Magdalenen-stromes"( = Río Magdalena) for the several fishes listed in that publication. In a subsequent paper, Steindachner (1879) provided a detailed description with illustrations, and indicated that the collecting site (1879: 20) of the $C$. magdalenae was Cienaga. That location is situated in the Colombia coast near the mouth of the río Magdalena (Fig. 23, asterisk). Later, Steindachner (1880:79) provided a list of fishes from the río Cauca and along with a short description of Chalcinus magdalenae " reported on "three specimens of 15-23 cm length". This citation has been misinterpreted by some subsequent authors who cite the río Cauca as the type locality for this species (Eschmeyer, 1998:1001). There are 15 specimens identified as syntypes of $C$. magdalenae deposited in NMW (NMW 69151 (7), NMW 69152 (2), NMW 69153 (4), and NMW 69154 (2), Mikschi and Wellendorf, pers. comm., 1999) and one syntype in the ZMC (Nielsen, 1974), all collected in the río Magdalena.

Non-type material. Colombia: Magdalena: FMNH 56321 (5 of 9), Cienaga ( $\left.10^{\circ} 15^{\prime} \mathrm{N}, 74^{\circ} 54^{\prime} \mathrm{W}\right)$; FMNH 69756 (10 of 91), Calamar $\left(10^{\circ} 15^{\prime} \mathrm{N}, 7^{\circ} 54^{\prime} \mathrm{W}\right)$; FMNH 69628 (7 of 149), Soplaviento $\left(10^{\circ} 22^{\prime} \mathrm{N}, 7^{\circ} 7^{\prime} \mathrm{W}\right)$. Cundinamarca: FMNH 56324 (10), Girardot

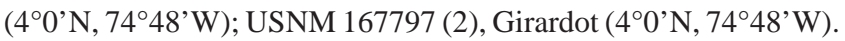
Antioquia: MZUSP 42201 (2), río Cauca, Caucasia $\left(8^{\circ} 0^{\prime} \mathrm{N}\right.$, 75¹1'W). Bolivar: USNM 175327 (6), río Viejo (8¹'N, 759'W). 


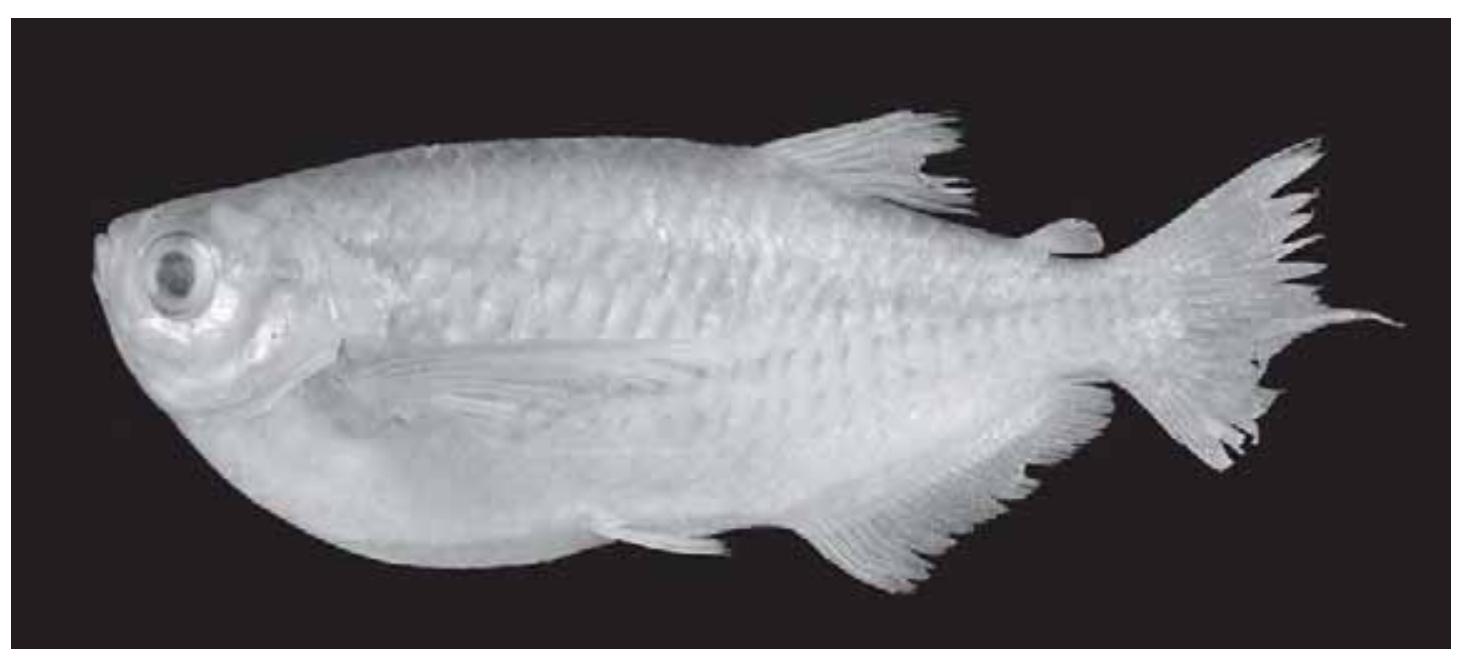

Fig. 24. Triportheus pantanensis, holotype, MCP 35006, $99.5 \mathrm{~mm}$ SL, Brazil, Mato Grosso, pond under bridge along Transpantaneira road, $70 \mathrm{~km} \mathrm{~S}$ of Poconé.

Tolima: FMNH 88185 (16), Honda $\left(8^{\circ} 38^{\prime} \mathrm{N}, 76^{\circ} 5^{\prime} \mathrm{W}\right)$; FMNH 56327 (5), Honda ( $\left.8^{\circ} 38^{\prime} \mathrm{N}, 7^{\circ} 5^{\prime} \mathrm{W}\right)$; USNM 079182 (3), Honda $\left(8^{\circ} 38^{\prime} \mathrm{N}, 76^{\circ} 5^{\prime} \mathrm{W}\right)$; USNM 116460 (1), Honda, Rio Magdalena ba$\sin \left(8^{\circ} 38^{\prime} \mathrm{N}, 76^{\circ} 5^{\prime} \mathrm{W}\right)$; FMNH 56328 (4 of 8), Puerta de Río, 1912; Manuel Gonzales [I have found no localities named Puerta de Río, in Colombia. According to Eigenmann (1922:4), Manuel Gonzales joined to his expedition from Bogota to Cartagena, but he listed no localities named Puerta de Río in his report (p.15-17)].

\section{Triportheus pantanensis, new species} Fig. 24

Triportheus nematurus. Portugal, 1990:166. Britski et al., 1999:29.

Holotype. Triportheus pantanensis, MCP 35006, 99.5 mm SL, rio Paraguay, pond under bridge along Transpantaneira road, $70 \mathrm{~km}$ S of Poconé, L. R. Malabarba \& R. E. Reis, 9 Feb 1986 (16ํำ's, 56 $\left.50^{\circ} \mathrm{W}\right)$.

Paratypes. Brazil: Mato Grosso: MCP 10751 (6, 77-84.7 mm SL), rio Paraguay, pond under bridge along Transpantaneira road, $70 \mathrm{~km}$ S of Poconé, L. R. Malabarba \& R. E. Reis, 9 Feb 1986 (1651'S, 56 50’ W); MCP 10733 (3, 92.7-94.5 mm SL), rio Pixaim on Porto de Pixaim, $60 \mathrm{~km}$ from Poconé, L. R. Malabarba \& R. E. Reis, 9Feb 1986 (16²45'S, 56 51'W); MCP 15741 (1, 88.6 $\mathrm{mm} \mathrm{SL}$ ), stream in Porto Estrada, on road to Barra do BugresCáceres $35 \mathrm{~km}$ S from Barra do Bugres, R. E. Reis, L. R. Malabarba \& N. A. Menezes, 11 Aug 1991 (15²4'S, 57 $15^{\circ}$ 'W); MCP 35824 (4, 68.3-81.5 mm SL), rio Paraguay in Cáceres and vicinity, R. E. Reis, L. R. Malabarba \& N. A. Menezes, 11 Aug 1991 (164'S, 57² '`W); MZUSP 27187 (2, 89,5-111.8 mm S) L, Taiamã, río Paraguay, A. S. Soares, 01-07 Dec 1980 (18²8’S, 5540’W). Paraguay: Presidente Hayes: NRM 31456 (11, 77.9-125.8 mm SL), Estancia La Rural, río Confuso, S. O. Kullander et al., 15 Oct 1994 (245ㅇ'S, 57²4'W); USNM 181682 (2, 107-117.5 mm SL), Asuncion Bay, río Paraguay, near Asuncion, C. J. D. Brown,
10 Jan 1957 ( $\left.25^{\circ} 15^{\prime} \mathrm{S}, 5^{\circ} 40^{\prime} \mathrm{W}\right)$; USNM 181689 (2, 137.2-158 $\mathrm{mm}$ SL), lago Ypacaray near San Bernardino, C. J. D. Brown, 11 Oct $1956\left(25^{\circ} 28^{\prime} \mathrm{S}, 57^{\circ} 33^{\prime} \mathrm{W}\right)$.

Diagnosis. A deep-bodied Triportheus species reaching 158 $\mathrm{mm} \mathrm{SL}$ (depth at dorsal-fin origin, 34.6-42.5, mean $=38.6 \% \mathrm{SL}, \mathrm{n}$ $=32$; depth at pectoral-fin insertion, 30.7-42.8, mean $=38.4 \%$ $\mathrm{SL}, \mathrm{n}=32$ ). The presence of 2 longitudinal scale rows between the pectoral-fin insertion and the ventral keel distinguishes this species from elongate-bodied Triportheus species that have 1 longitudinal scale row between the pectoral-fin insertion and the ventral keel. Among deep-bodied Triportheus species, $T$. pantanensis differs from its congeners by the combination of few gill rakers on the lower limb of the first gill arch (26-33, mean $=29.1, \mathrm{n}=29)$; the lateral-line scales counts $(28-33$, mean $=31.1, \mathrm{n}=32)$, the bony head length $(22.5-27.3$ of SL, mean = 25.1 , the snout to anal-fin origin distance (66.4-74.1, mean = $70.2)$, the length of anal-fin base (25.5-31.0, mean $=28.1)$, and the possession of median caudal-fin rays that extend well beyond the caudal-fin margin.

Description. Morphometric data for Triportheus pantanensis presented in Table 16. Body deep and compressed laterally. Greatest body depth located slightly posterior to vertical through pectoral-fin insertion. Dorsal profile of head straight from margin of snout to rear of head. Dorsal profile of body gently convex from rear of head to dorsal-fin origin; posteroventrally slanted from dorsal-fin origin to caudal peduncle; and slightly concave along caudal peduncle.

Ventral profile of head straight from margin of lower lip to anteroventral margin of dentary; distinctly convex from that point to pelvic-fin insertion; slightly convex from pelvicfin insertion to anal-fin origin; posterodorsally slanted along anal-fin base; straight along caudal peduncle. Prepelvic region distinctly expanded ventrally and laterally flattened, with well developed keel. 
Table 16. Morphometrics of Triportheus pantanensis. Ranges include measurements of 31 paratypes: MCP 10751 (6), MCP 10733 (3), MCP 15741 (1), MCP 35824 (4), MZUSP 27187 (2), NRM 31456 (11), USNM 181682 (2), USNM 181689 (2).

\begin{tabular}{|c|c|c|c|c|}
\hline Character & Holotype & $\mathrm{N}$ & Range & Mean \\
\hline Standard length $(\mathrm{mm})$ & 99.5 & 31 & $67.7-158.0$ & 93.4 \\
\hline \multicolumn{5}{|c|}{ Percents of standard length } \\
\hline Bony head length & 26.0 & 31 & $22.5-27.3$ & 25.1 \\
\hline Snout to anal-fin origin & 70.0 & 31 & $66.4-74.1$ & 70.2 \\
\hline Snout to dorsal-fin origin & 60.6 & 31 & $59.3-64.6$ & 61.9 \\
\hline Snout to pelvic-fin origin & 51.9 & 30 & $49.9-66.9$ & 54.2 \\
\hline Ana & 28.7 & 30 & 25. & 28.1 \\
\hline gth & 6.7 & 31 & $5.5-$ & 7.3 \\
\hline Caudal peduncle & 11.0 & 31 & $9.2-11.1$ & 10.1 \\
\hline Depth & 36.4 & 31 & $34.6-42.5$ & 38.7 \\
\hline Depth at pectoral fin & 36.8 & 31 & $30.7-42.8$ & 38.5 \\
\hline fin height & 19.8 & 31 & $18.0-22.8$ & 20.6 \\
\hline & 13.9 & 30 & & 14.6 \\
\hline Pectoral-fin length & 38.8 & 31 & $32.9-42.7$ & 39.1 \\
\hline \multicolumn{5}{|c|}{ Percents of head length } \\
\hline & 21.6 & 31 & $18.2-25.2$ & 21.2 \\
\hline Upper jaw length & 24.3 & 31 & $21.1-26.3$ & 23.9 \\
\hline Horizontal eye diameter & 30.1 & 31 & $25.0-32.5$ & 29.1 \\
\hline Least interorbital width & 35.1 & 31 & $31.6-38.9$ & 35.4 \\
\hline
\end{tabular}

Head blunt in profile; posterior margin of opercle falling short of vertical through pectoral-fin insertion. Mouth terminal; lower jaw as long as upper jaw. Nostrils of each side close together; anterior opening circular, posterior elongate.

Gill rakers thin and close together, length equivalent to one-half length of branchial filament; gill rakers on lower limb of first gill arch 26-33 [30] $($ mean $=29.1, n=29)$.

Teeth on premaxilla in 3 rows with teeth of inner row largest. Four or 5 cusp teeth on outer row, and arranged along external margin of mouth and visible externally in closed mouth. Medial tooth row with 3 tricuspidate teeth. Six, rarely 7 , multicuspidate teeth on inner row in premaxilla. Maxilla with 0-2 flattened teeth much smaller than those of premaxilla. Teeth on lower jaw in 2 rows, outer row with 4-5 larger anterior teeth and 4 to 6 smaller posterior teeth. Inner row with conical symphyseal tooth.

Scales cycloid, thin, and large. Lateral line distinctly decurved ventrally, completely pored from supracleithrum to base of caudal-fin rays. Scales in lateral line 28-33 [30] (mean $=31.1, \mathrm{n}=32$ ); 6 scale series above lateral line; 2-3 scale rows below lateral line. Two scale rows between pectoralfin insertion and midventral keel; 5-6 scale series on caudal peduncle. Scales along mid-dorsal line very irregular, 6-13 (mean $=10.2, \mathrm{n}=29)$ scales from supraoccipital process to dorsal-fin origin.

Dorsal-fin rays ii,9; anal-fin rays iii,25-30 [29] $($ mean $=$ $27.9, \mathrm{n}=31$ ); pectoral-fin rays i,10-12 [12]; pelvic-fin rays i,6. Dorsal-fin distal margin straight. Dorsal fin situated on posterior one-half of body. Last dorsal-fin ray located at vertical through base of third or fourth anal-fin ray; first branched ray longest; following rays gradually decreasing in length. Pectoral fin pointed, with tip reaching vertical through distal one-third of pelvic fin. Anal fin margin straight; first branched anal-fin ray longest, following rays gradually decreasing in length. Margin of caudal fin truncate; median rays extending one-half of their length beyond margin of remainder of fin. Scales cover basal onethird of caudal fin.

Total vertebrae 36-37.

Coloration in alcohol. Overall ground color yellowish and overlain in areas by guanine. Snout and dorsal portions of head dark. Scattered dark chromatophores present on opercle and infraorbitals 5 and 6. Body darker dorsally and above anal-fin base and on caudal peduncle. Five or 6 longitudinal brown stripes present on dorsolateral portion of body. Dorsal-fin rays outlined by dark chromatophores. Chromatophores distributed over pectoral-fin membranes, with more intense pigmentation on first unbranched ray. Anal-fin margin darkened. Middle caudalfin rays very dark.

Remarks. This species was previously erroneously referred to as Chalcinus nematurus or Triportheus nematurus by Ribeiro (1941), Fowler (1975), Portugal (1990), and Britski et al. (1999). Triportheus nematurus, however, is a distinct species. See remarks under Triportheus nematurus.

Distribution. Río Paraguay and lower rio Paraná basins (Fig. 23).

Etymology. The species name, pantanensis, refers to the Pantanal de Mato Grosso, region where the new species commonly occurs and should be considered in apposition to the genus name.

\section{Triportheus orinocensis, new species}

Fig. 25

Holotype. MZUSP 85804, 85.49 mm SL. Venezuela, Guarico, caño to West of road from Calabozo to San Fernando, about $35 \mathrm{~km}$ south to Fundo Masaguaral, caño Falcon, R. Vari et al., 20 Jan $1983\left(8^{\circ} 14^{\prime} \mathrm{N}, 67^{\circ} 35^{\prime} \mathrm{W}\right)$.

Paratypes. Venezuela: Guarico: MZUSP 27968 (7, 62.5-79.2 mm SL), same data as holotype. USNM 258037 (7, 65.8-124.8 mm SL), ponds to W of caño Falcon, R. P. Vari et al., 20 Jan 1983 ( $\left.8^{\circ} 14^{\prime} \mathrm{N}, 67^{\circ} 35^{\prime} \mathrm{W}\right)$; USNM 260134 (7, 87.3-93.7 mm SL), río Caracol where crossed by bridge on ranch, Fundo Masaguaral, R. P. Vari et al., 20 Jan 1983 (08³4'N, 67³0’W); INHS 98930 (2, 76.6-85.4), UNELLEZ 51999 (3, 76.6-82.1 mm SL), ANSP 180379 (1,85.8 mm SL), MBUCV-V-32265 (3, 74.1-85.9), MCP 35825 (1, $102.6 \mathrm{~mm} \mathrm{SL}), 74.1-76.6 \mathrm{~mm} \mathrm{SL}$, río Apurito, at mouth of río Guariquito, J. W. Armbruster \& P. Ceas, 14 Jan 1995 (07²4' N, $\left.66^{\circ} 31^{\prime} \mathrm{W}\right)$; INHS 35870 (2, 81-112.9 mm SL), río Cajauito SE of "El Carote" near mouth, D. C. Taphorn et al., 12 Jan 1995 (07²1'N, 66²1'W); INHS 69510 (1, 134.5 mm SL), río Los Aceites, 15 km SSE of Palenque, D. C. Taphorn, L. M. Page, K. 


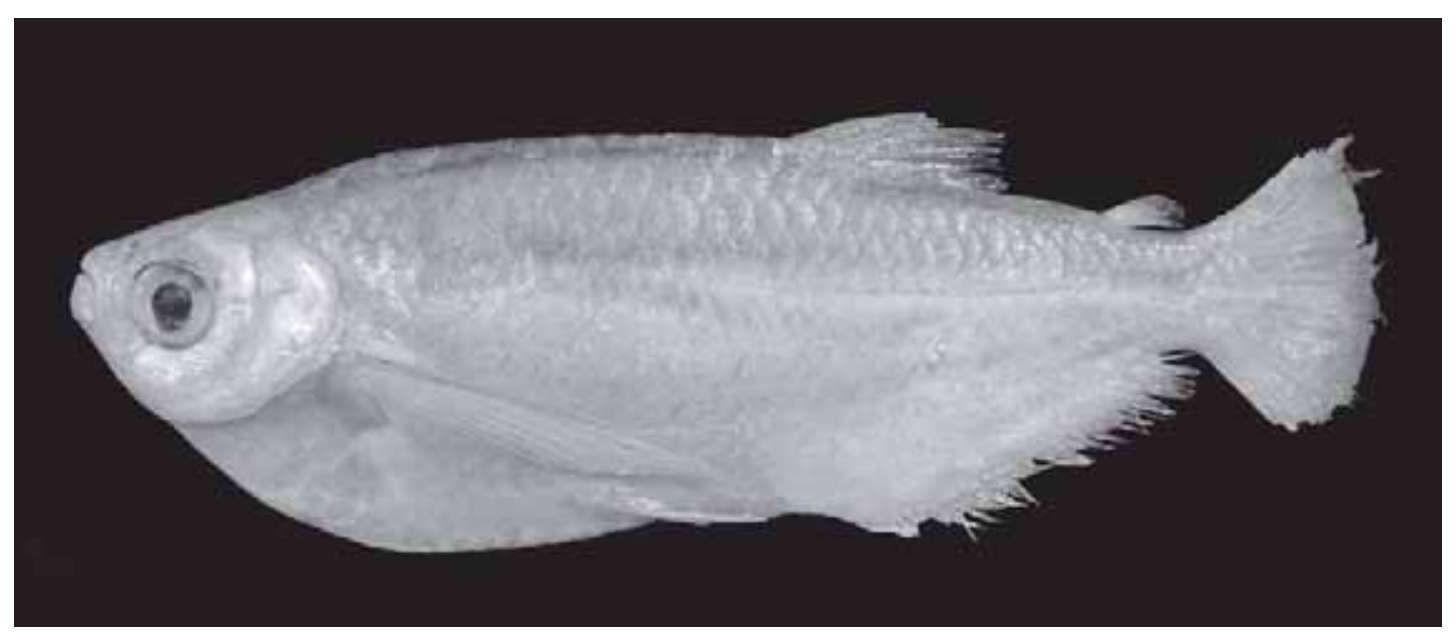

Fig. 25. Triportheus orinocensis, holotype, MZUSP 85804, 85.49 mm SL, Venezuela, Guarico, caño Falcon.

Table 17. Morphometrics of Triportheus orinocensis. Ranges include measurements of paratypes: USNM 258037 (7), USNM 260134 (7), USNM 233640 (12), USNM 348707 (5), USNM 257992 (2), USNM 258120 (4), USNM 233225 (1), ANSP 180379 (1), MBUCV-V-32265 (3), UNELLEZ 51999 (3), INHS 98930 (2), MCP 35825 (1), INHS 98929 (5), INHS 69510 (1), INHS 35870 (2), INHS 32014 (1), MZUSP 27968 (1 of 7).

\begin{tabular}{lcccc}
\hline \multicolumn{1}{c}{ Character } & Holotype & $\mathrm{N}$ & Range & Mean \\
\hline Standard length (mm) & 85.49 & 58 & $57.6-144.3$ & 82.0 \\
& Percents of standard length & & \\
Bony head length & 23.65 & 58 & $21.9-27.6$ & 25.7 \\
Snout to anal-fin origin & 71.23 & 58 & $67.2-75.0$ & 70.6 \\
Snout to dorsal-fin origin & 62.32 & 58 & $58.8-63.7$ & 61.4 \\
Snout to pelvic-fin origin & 50.09 & 56 & $51.2-56.4$ & 53.5 \\
Anal-fin base length & 30.76 & 58 & $26.3-33.0$ & 28.9 \\
Caudal peduncle length & 5.61 & 58 & $4.2-10.4$ & 6.7 \\
Caudal peduncle depth & 9.80 & 56 & $8.9-10.9$ & 10.1 \\
Depth at dorsal-fin origin & 34.64 & 58 & $28.7-37.1$ & 33.4 \\
Depth at pectoral fin & 35.04 & 58 & $32.2-39.3$ & 35.6 \\
Dorsal-fin height & 20.22 & 48 & $11.4-22.9$ & 18.8 \\
Pelvic-fin length & 12.92 & 52 & $9.1-15.9$ & 12.8 \\
Pectoral-fin length & 38.37 & 55 & $32.5-40.9$ & 36.8 \\
& 24.28 & 58 & $19.2-24.6$ & 22.6 \\
Snout length & 27.99 & 58 & $21.8-29.4$ & 25.0 \\
Upper jaw length & 34.07 & 58 & $24.0-35.1$ & 28.4 \\
Horizontal eye diameter & 34.91 & 58 & $31.5-38.6$ & 34.0 \\
Least interorbital width & \multicolumn{3}{c}{} \\
\hline
\end{tabular}

S. Cummings \& D. A. Carney, 21 Jan $1986\left(08^{\circ} 52^{\prime} \mathrm{N}, 66^{\circ} 54^{\prime} \mathrm{W}\right)$. Portuguesa: INHS 35635 (1, 104.7 mm SL), caño Maraca on road from Guanare to Guanarito at $60 \mathrm{~km}$ marker, P. A. Ceas, J. W. Armbruster et al., 1 Jan 1995 (849’N, 69²0'W); INHS 98929 (5, 73.8-144.3 mm SL), Puerto Papelon, caño Igues, D. Rodriguez \& P. Pacheco, 17 Dec $1992\left(8^{\circ} 34^{\prime} \mathrm{N}, 68^{\circ} 5^{\prime} \mathrm{W}\right)$; USNM 348707 (5, 58.3-68.3 mm SL), río Portuguesa, caño Maraca, J. W. Armbruster et al., 24 Dec 1998 (849’N, 69²0’W). Cojedes: INHS 32014 (1, $68.6 \mathrm{~mm}$ SL), río San Carlos, caño Hondo, $5 \mathrm{~km}$ S of Las Vegas (9³4'N, 68 ${ }^{\circ}$ 'W). Apure: USNM 257992 (2, 71.5$74.6 \mathrm{~mm} \mathrm{SL}$ ), side channel of río Apure 5k W of San Fernando de Apure, technicians at Apure fisheries, 21 Jan 1983 (0753'N, $\left.67^{\circ} 29^{\prime} \mathrm{W}\right)$; USNM 258120 (4, 57.5-67.5 mm SL), río El Canito where crossed by road from San Fernando to Cunaviche, 22
Jan $1983\left(07^{\circ} 28^{\prime} \mathrm{N}, 6^{\circ}{ }^{\circ} 39^{\prime} \mathrm{W}\right)$. Bolivar: USNM 233640 (12, 66.2$85.3 \mathrm{~mm} \mathrm{SL}$ ), Los Castillos, isolated lagoon on isla Tapatapa, Marsh et al., 10 Nov 1979 ( $\left.08^{\circ} 31^{\prime} \mathrm{N}, 62^{\circ} 26^{\prime} \mathrm{W}\right)$; USNM 233225 (1, $101.9 \mathrm{~mm} \mathrm{SL})$, caño Araguaito, $129 \mathrm{~km}$ from sea buoy, J. Baskin \& D. Stewart, 13 Nov $1979\left(08^{\circ} 40^{\prime} \mathrm{N}, 62^{\circ} 51^{\prime} \mathrm{W}\right)$.

Diagnosis. A deep-bodied Triportheus species reaching $144.3 \mathrm{~mm}$ of SL (depth at dorsal-fin origin, 28.7-37.1, mean = $33.4 \% \mathrm{SL}, \mathrm{n}=58$; depth at pectoral-fin insertion, 32.2-39.3, mean $=35.6 \% \mathrm{SL}, \mathrm{n}=58$ ). This species is readily distinguished from its congeners by the extensive scaling over the caudal and anal fins. The presence of 2 longitudinal scale rows between the pectoral-fin insertion and the ventral keel distinguishes this species from elongate-bodied Triportheus species that have 1 longitudinal scale row between the pectoral-fin insertion and the ventral keel. Triportheus orinocensis further differs from deep-bodied congeners, by the combination of the number of gill rakers on the lower limb of the first gill arch (24-28, mean $=25.8, \mathrm{n}$ $=37$ ); the number of branched anal-fin rays (28-32, mean = $29.9, \mathrm{n}=35)$; and the number of lateral-line scales (34-39, mean $=37.2, \mathrm{n}=31$ ).

Description. Morphometric data for Triportheus orinocensis presented in Table 17. Body deep and laterally compressed. Greatest body depth located slightly posterior to vertical through pectoral-fin insertion. Dorsal profile of head straight from margin of upper lip to rear of head. Dorsal profile of body gently curved from rear of head to dorsal-fin origin; posteroventrally slanted from dorsal-fin origin to caudal peduncle; straight along caudal peduncle. Laterodorsal portion of body slightly keeled.

Ventral profile of head straight from margin of lower lip to anteroventral margin of dentary. Ventral profile of body arched from base of dentary to pelvic-fin insertion; nearly straight from that point to anal-fin origin; gently curved along analfin base; straight along caudal peduncle. Prepelvic region distinctly expanded ventrally and laterally flattened, with welldeveloped keel. 
Head blunt in profile; posterior margin of opercle falling short of pectoral-fin insertion. Snout vertically straight. Mouth terminal; lower jaw as longer as upper jaw. Nostrils of each side close together; anterior opening circular; posterior elongate.

Gill rakers thick and separated, length equivalent to onehalf length of branchial filament; gill rakers on lower limb of first arch 24-28 [25] ( mean = 25.8, $\mathrm{n}=37)$.

Teeth on premaxilla in 3 rows; with teeth of inner row largest. Four to 5 tricuspidate teeth on outer row; outer row teeth arranged along external margin of mouth and visible externally in closed mouth. Medial tooth row with 3 tricuspidate teeth. Seven multicuspidate teeth on inner row of premaxilla. Maxilla with 2-3 tricuspidate teeth smaller than those of premaxilla. Teeth on lower jaw in 2 rows, outer row with 5 larger tricuspidate to pentacuspidate teeth, followed by 3-4 much smaller, tricuspidate teeth.

Scales cycloid, thin, and large. Lateral line distinctly decurved ventrally, completely pored from supracleithrum to base of caudal-fin rays. Thirty-four to 39 [39] (mean $=37.2, \mathrm{n}$ $=31$ ) scales in lateral line; seven scale series between lateral line and dorsal-fin origin; 2 scale rows from lateral line to pelvic-fin insertion. Two scale rows between pectoral-fin insertion and midventral keel; 5 scale series on caudal peduncle. Scales along mid-dorsal line very irregular, with 6-13 [9] (mean $=8.4, \mathrm{n}=17$ ) scales from tip of supraoccipital spine to dorsalfin origin.

Dorsal-fin rays ii,9; anal-fin rays iii,28-32 [29] $($ mean $=29.9$, $\mathrm{n}=35)$; pectoral-fin rays $\mathrm{i}, 10-13$ [11] ( pelvic-fin rays i,6. Dorsal-fin margin straight, situated on posterior one-half of body; base of last dorsal-fin ray situated approximately along vertical through base of seventh analfin ray; second unbranched and first branched dorsal-fin ray slightly longer than following rays. Pectoral fin pointed, tip extending posteriorly to vertical through middle of pelvic fin. Anal fin margin slightly curved, first branched anal-fin ray longest, and following rays gradually decreasing in length. Four or five series of scales overlying basal portions of analfin rays, and covering one-half of length of rays. Margin of caudal fin truncate to slightly rounded. Scales covering nearly entire fin.

Total vertebrae 37-38 [37].

Coloration in alcohol. Overall ground color yellowish brown. Snout and dorsal portion of head dark. Some scattered dark chromatophores present on opercle. Body with dark midlateral stripe extending from supracleithrum posteriorly to caudal peduncle; stripe expanding vertically posteriorly and broadened into wider diffuse dark spot on lateral surface of caudal peduncle. Body darker dorsal to stripe. Dorsal-fin rays lightly outlined by dark chromatophores. Scattered chromatophores distributed all over pectoral fin; with more intense pigmentation on first unbranched ray and along fin margin. Caudal-fin border dark.

Distribution. Río Orinoco basin (Fig. 23).
Etymology. Species name, orinocensis, from the Río Orinoco, where the new species occurs. The name is treated as a name in apposition.

\section{Triportheus venezuelensis, new species} Fig. 26

Holotype. INHS 34768, 118.64 mm SL, Venezuela, Barinas, río Masparro, Apure drainage, $5 \mathrm{~km}$ NW Libertad on road to Barinas, 25 Jan 1995, L. M. Page, J. W. Armbruster, P. A. Ceas, K. S. Cummings \& C. A. Mayer $\left(08^{\circ} 20^{\prime \prime N}\right.$, 6939”'W).

Paratypes. Venezuela: Bolivar: USNM $270343(17,65.7-83.4 \mathrm{~mm}$ SL), UNELLEZ 52000 (3, 73-83.4 mm SL), small caño connecting with rio Orinoco immediately South of El Burro, 9 Dec 1984, R. Vari, O. Castillo \& C. Ferraris ( $06^{\circ} 11^{\prime}$ N, 67’25'W); INHS 35077 (4, 80.6-83.1 mm SL), laguna Castillero, 10 Jan 1988, M. Rodriguez (07³8'N, 6609'W). Apure: USNM 258079 (6, 76-85 mm SL), río Apure, W of town center, 25 Jan 1983, O. Costillo et al. (7 $7^{\circ} 53^{\prime} \mathrm{N}$; $\left.67^{\circ} 29^{\prime} \mathrm{W}\right)$; FMNH 85488 (10, 36.3-73.6 mm SL), river $24 \mathrm{~km} \mathrm{~S}$ of Biruaca on road to San Juan de Apayara, 7 Jan 1975, J. Thomerson \& D. Taphorn ( $\left.07^{\circ} 56^{\prime} \mathrm{S}, 6^{\circ} 5^{\prime} \mathrm{W}\right)$. Monagas: USNM 233784 (12, 75.6-94.6mm SL); USNM358223 (5,73.5-87.7 mm SL); MCP 35842 $(1,82.4 \mathrm{~mm} \mathrm{SL})$, río Orinoco, laguna Tapatapa on Isla Tapatapa near downstream end of caño Limon, 16 Feb 1978, J. Lundberg \& Lopez (8³2'N, 62²6’W). Guarico: INHS 34573 (3, 68.1-69.8 mm SL), laguna Caricare, 14 Jan 1995, J. Armbruster, P. Ceas, M. Campos, R. Suarez \& J. Llerandi (750'N, 66²32'W); INHS 34484 (2, 82.4-83.1 mm SL), río San Bortolo at Águas Muertas, 8 Jan 1995, L. M. Page et al. (0804' N, 4050’ W); INHS 35294 (3, 74.377.9 mm SL), río Orinoco, laguna Larga Ii, 12 Jan 1987, M. A. Rodríguez \& S. Richardson ( $\left.07^{\circ} 38^{\prime} \mathrm{N}, 66^{\circ} 13^{\prime \prime W}\right)$; INHS 35114 (8, 63.1-77.3 mm SL), río Aguaro, P. N. Aguaro-Guariquito en El Paso, L. M. Page et al., 11 Jan 1995 (0750’N, 66³0’W).

Diagnosis. A deep-bodied Triportheus species reaching $94.9 \mathrm{~mm}$ SL (depth at dorsal-fin origin, 26.7-37.6, mean $=32.9 \%$ SL, $\mathrm{n}=54$; depth at pectoral-fin insertion, 29.2-38.4, mean $=36.1 \% \mathrm{SL}, \mathrm{n}=55$ ). The presence of 2 longitudinal scale rows between the pectoralfin insertion and the ventral keel distinguish this species from elongate-bodied Triportheus species that have 1 longitudinal scale row between the pectoral-fin insertion and the ventral keel. Triportheus venezuelensis is distinguished among deep bodied congeners by the combination of the number of gill rakers on the lower limb of the first gill arch $(27-33$, mean $=30.1, \mathrm{n}=55)$; the number of branched anal-fin rays $(24-27$, mean $=25.6, \mathrm{n}=54)$; and the number of lateral-line scales $(33.0-36.0$, mean $=34.0 \mathrm{n}=51)$.

Description. Morphometric data for Triportheus venezuelensis presented in Table 18. Body deep and compressed laterally. Greatest body depth located slightly posterior to vertical through pectoral-fin insertion. Dorsal profile of head straight from upper lip to rear of head. Dorsal profile of body gently curved from rear of head to dorsal-fin origin; 


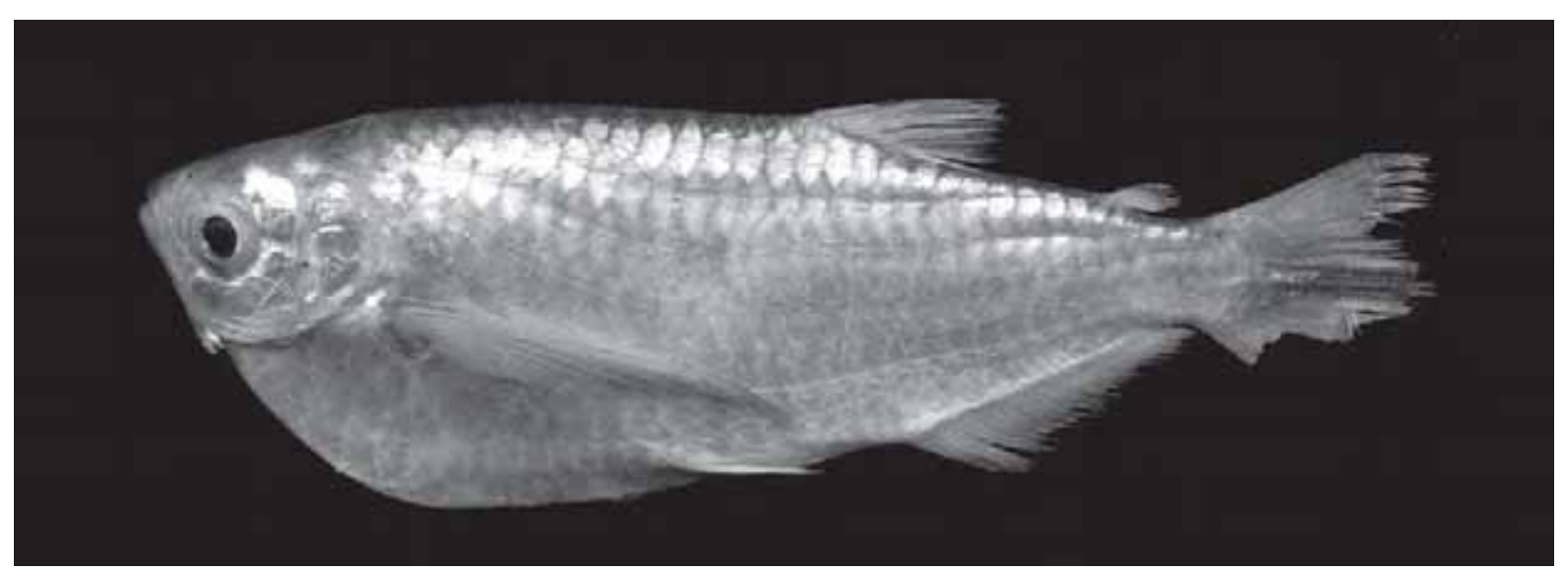

Fig. 26. Triportheus venezuelensis, holotype, INHS 34768, $118.64 \mathrm{~mm}$ SL, Venezuela, Barinas, río Masparro, río Apure drainage, $5 \mathrm{~km} \mathrm{NW}$ of Libertad on road to Barinas.

Table 18. Morphometrics of Triportheus venezuelensis. Ranges include measurements of 55 paratypes: USNM 258079 (6), USNM 233784 (12), USNM 270343 (17), UNELLEZ 52000 (3), FMNH 85488 (10), INHS 34573 (3), INHS 35077 (4).

\begin{tabular}{lcccc}
\hline \multicolumn{1}{c}{ Character } & Holotype & $\mathrm{N}$ & Range & Mean \\
\hline Standard length (mm) & 118.6 & 55 & $36.3-94.6$ & 74.0 \\
& Percents of standard length & & \\
Bony head length & 25.6 & 55 & $24.2-30.5$ & 26.1 \\
Snout to anal-fin origin & 73.7 & 54 & $69.7-79.3$ & 73.4 \\
Snout to dorsal-fin origin & 61.6 & 55 & $57.5-62.3$ & 60.3 \\
Snout to pelvic-fin origin & 53.8 & 52 & $49.9-57.7$ & 54.7 \\
Anal-fin base length & 24.2 & 55 & $20.0-26.0$ & 24.1 \\
Caudal peduncle length & 6.7 & 55 & $4.8-10.3$ & 8.3 \\
Caudal peduncle depth & 9.2 & 55 & $8.5-10.1$ & 9.3 \\
Depth at dorsal-fin origin & 32.1 & 54 & $26.7-37.6$ & 32.9 \\
Depth at pectoral fin & 36.3 & 55 & $29.2-38.4$ & 36.1 \\
Dorsal-fin height & 18.6 & 53 & $18.2-22.5$ & 20.2 \\
Pelvic-fin length & 14.8 & 50 & $12.2-20.0$ & 14.9 \\
Pectoral-fin length & 38.4 & 53 & $32.3-43.1$ & 38.2 \\
& 20.6 & 55 & $18.3-23.2$ & 21.1 \\
Snout length & 26.3 & 55 & $22.7-31.7$ & 25.9 \\
Upper jaw length & 31.0 & 55 & $24.8-34.8$ & 30.7 \\
Horizontal eye diameter & 29.9 & 55 & $27.4-34.8$ & 31.1 \\
Least interorbital width & & & & \\
\hline
\end{tabular}

posteroventrally slanted from dorsal-fin origin to caudal peduncle; curved along caudal peduncle. Dorsal portion of body slightly keeled.

Ventral profile of head straight from tip of lower lip to anteroventral margin of dentary. Ventral profile of head and body arched from base of dentary to pelvic-fin insertion; slightly curved or almost straight from pelvic-fin insertion to anal-fin origin; posterodorsally slanted along anal-fin base; straight along caudal peduncle. Prepelvic region expanded ventrally and strongly keeled.

Head blunt in profile; posterior margin of opercle almost reaching vertical through pectoral-fin insertion. Snout vertically straight. Mouth terminal; upward. Lower jaw as long as upper jaw. Nostrils of each side close together; anterior opening circular; posterior elongate.

Gill rakers thick and separated; length equivalent to one-half of length of branchial filament; gill rak- ers on lower limb of first arch 27-33 [32] ( mean $=30.1$, $\mathrm{n}=55)$.

Teeth on premaxilla in 3 rows; with teeth of inner row largest. Five tricuspidate teeth of outer row arranged along external margin of mouth and externally visible in closed mouth. Medial row with 3 tricuspidate teeth. Seven multicuspidate teeth on inner row on premaxilla. Maxilla with 2-3 tricuspidate teeth smaller than those on premaxilla. Teeth on lower jaw in 2 rows, outer row with 5 medial teeth, followed by 3-4 much smaller, tricuspidate teeth. Inner row consisting of conical posteriorly curved symphyseal tooth.

Scales cycloid, thin, and large. Lateral line distinctly decurved ventrally, completely pored from supracleithrum to base of caudal-fin rays. Thirty-three to 36 [33] ( mean $=34.1, \mathrm{n}$ $=50$ ) scales in lateral line; 5-6 scale series between lateral line and dorsal-fin origin; two scale rows between lateral line and pelvic-fin insertion. Two scale rows between pectoral-fin insertion and midventral keel; 4-5 scale series on caudal peduncle. Scales along mid-dorsal line very irregularly arranged with 6-12 scales from tip of supraoccipital spine to dorsal-fin origin.

Dorsal-fin rays ii,9; anal-fin rays iii,24-27 [25] (mean $=25.6$, $\mathrm{n}=54)$; pectoral-fin rays i,10-12 [10] (mean $=11.6, \mathrm{n}=50)$; pelvic-fin rays i,6. Base of dorsal-fin situated on posterior onehalf of body; base of last dorsal-fin ray located anterior to vertical through anal-fin origin; second unbranched and first branched ray longest with following rays gradually decreasing in length. Pectoral fin pointed with tip extending posteriorly as far as vertical through middle of pelvic fin. Anal-fin margin slightly curved, first branched anal-fin ray longest with following rays gradually decreasing in length. One or 2 series of scale overlaying basal portions of anal-fin rays. Margin of caudal fin truncate with median rays extending for one-half of their length beyond margin of remainder of fin.

Total vertebrae 38 .

Coloration in alcohol. Overall ground color yellowish brown. Snout and dorsal portion of head dark. Some scattered dark 
chromatophores present on opercle and postorbital region. Concentration of chromatophores forming diffuse stripe extending from supracleithrum to caudal peduncle; stripe broadened into wider dark spot on lateral surface of caudal peduncle. Body darker dorsal to midlateral stripe. Dorsal-fin rays outlined by dark chromatophores. Scattered dark chromatophores distributed all over pectoral fin; with more intense dark pigmentation on first unbranched ray and along fin margin. Some dark chromatophores outlining anal-fin rays. Median caudal-fin rays dark.

Distribution. Río Orinoco basin (Fig. 12).

Etymology. Species name, venezuelensis, refers to the country drained by Río Orinoco and must be considered in apposition to the genus name

\section{Discussion}

The external morphology of the species of Triportheus is markedly similar. The species are so conservative that in some instances it is difficult to find diagnostic characters easily recognizable among some of its components. However, two groups of species can be easily recognized: the elongated (T. albus, T. auritus, T. brachipomus, T. culter, $T$. magdalenae) and the deep-bodied species (T. angulatus, $T$. curtus, T. guentheri, T. nematurus, T. orinocensis, T. pantanensis, $T$. pictus, $T$. rotundatus, $T$. signatus, $T$. trifurcatus and T. venezuelensis). Besides the differences in body depth/standard length proportions, as presented in each diagnosis, the species of each of these groups present different patterns in some characters that further allow the informal recognition of each group. In the elongated species, the scales of one of the scale rows filling the space between the pectoral fin insertion and the midventral keel are distinctly larger than the regular scales covering the body. In the deep-bodied species this space is occupied by two rows of regular sized scales. The pigmented longitudinal sinuous bars (5-6) that usually occur laterally on the body of deep-bodied species, does not exist in the elongated species which usually have only one longitudinal bar from opercle to caudal peduncle. The arrangement of the premaxilary teeth is also different in the two groups. In the deep-bodied species 3 tooth rows are defined (the intermediate row always with less teeth), while in the elongated ones a middle row is not clearly recognizable. Although these characters have not been phylogeneticaly evaluated, the patterns detected above suggest a potential use for relationship studies that deserves to be investigated.

\section{Acknowledgments}

For loaning specimens, providing information or photographs we thank Barry Chernoff and Mary Anne Rogers (FMNH), Douglas W. Nelson and William L. Fink (UMMZ), Francisco Provenzano (MBUCV), Franco Andreone (MZUT),
Helmut Wellendorf and Ernst Mikschi (NMW), Hernan Ortega (MUSM), Horst Wilkens (ZMH), J-C. Hureau and Guy Duhamel (MNHN), Jon Armbruster (AUM), John Lundberg and Mark Sabaj (ANSP), Jon Fon (CAS), Karsten Hartel (MCZ), Lígia N. Aranguren, F. Estela Freitas and Lisandro S. Vieira (UFAC), Michael Retzer (INHS), Osvaldo T. Oyakawa (MZUSP), Paulo A. Buckup (MNRJ), Scott A. Schaeffer and Barbara Brown (AMNH), Sven O. Kullander and Erik Ahlander (NRM), and Vinicius Bertaco (MCP). Most of this paper was developed as a postdoctoral project in the Division of Fishes (NMNH, SI) under direction of Richard P. Vari. Assistance of all Division of Fishes staff is gratefully acknowledged. Sandra Raredon assisted us with laboratory work and radiographing dozens of specimens. Luiz R. Malabarba and S. H. Weitzman provided photographs of the specimens. The distribution maps are based on a map of South America prepared by Marilyn Weitzman (NMNH). Richard P. Vari reviewed an early draft of this manuscript. Discussions on Triportheus species with S. H. Weitzman and L. R. Malabarba greatly improved this manuscript.

\section{Literature cited}

Böhlke, E. B. 1984. Catalog of type specimens in the ichthyological collection of the Academy of Natural Sciences of Philadelphia. Academy of Natural Sciences of Philadelphia, Special Publication, 14:1-246.

Bertoni, A. W. 1939. Catálogos sistemáticos de los Vertebrados del Paraguay. Revista de la Sociedad Cientifica de Paraguay, 4(4):1-60.

Britski, H. A., Y. Sato, \& A. B. S. Rosa. 1984. Manual de identificação de peixes da região de Três Marias (com chaves de identificação para os peixes da bacia do São Francisco). Cia. de Desenvolvimento do Vale do São Francisco, Brasília, 143p.

Britski, H. A., K. Z. de Silimon \& A. S. Lopes. 1999. Peixes do Pantanal. Embrapa, Brasília, 184p.

Castelnau, F. de. 1855. Animaux nouveaux ou rares recueillis pendant l'expédition dans les parties centrales de l'Amérique du Sud. Part 7, Zoology, 2:1-112.

Cope, E. D. 1872. On the fishes of the Ambyiacu River. Proceedings of the Academy of Natural Sciences of Philadelphia, 23: 250-294.

Cope, E. D. 1878. Synopsis of the fishes of the Peruvian Amazon, obtained by Professor Orton during his expeditions of 1873 and 1877. Proceedings of the American Philosophical Society, 17:673-701.

Cuvier, G. \& A. Valenciennes. 1850. Histoire naturelle des poissons. P. Bertrand, Paris [Published as 1849], v. 22: 395p.

De Filippi, P. 1853. Nouvelles espèces de poissons. Revue et magasin de Zoologie pure et appliquée, Ser. 2, 5: 164-171.

Eigenmann, C. H. 1910. Catalogue of the fresh-water fishes of tropical and south temperate America. In: Reports of the Princeton University expeditions to Patagonia 1896-1899. Zoology, 3(4):375-511.

Eigenmann, C. H. 1912. The freshwater fishes of British Guiana, 
including a study of the ecological grouping of species, and the relation of the fauna of the plateau to that of the lowlands. Memoirs of the Carnegie Museum, 5(1):1-578.

Eigenmann, C. H. 1922. The fishes of western South America, Part I. The fresh-water fishes of northwestern South America, including Colombia, Panama, and the Pacific slopes of Ecuador and Peru, together with an appendix upon the fishes of the rio Meta in Colombia. Memoirs of the Carnegie Museum, 9(1):1-346.

Eigenmann, C. H. \& W. R. Allen. 1942. Fishes of western South America 1. The intercordilleran and Amazonian lowlands of Peru. 2. The high pampas of Peru, Bolivia, and Northern Chile with a revision of the Peruvian Gymnotidae, and of the genus Orestias. The University of Kentucky, Lexington, 494p.

Eigenmann, C. H. \& B. A. Bean. 1907. An account of Amazon River Fishes collected by J. B. Steere, with a note on Pimelodus clarias. Proceedings of the United States National Museum, 31:659-668.

Eigenmann, C. H. \& R. S. Eigenmann. 1891. A catalogue of the fresh-water fishes of South America. Proceedings of the United States National Museum, 14:1-81.

Eschmeyer, W. N. 1998. Catalog of fishes. California Academy of Sciences, San Francisco, 2905p.

Fink, W. L. \& S. H. Weitzman. 1974. The so-called cheirodontin fishes of Central America with descriptions of two new species (Pisces: Characidae). Smithsonian Contributions to Zoology, Washington, 172:1-46.

Fowler, H. W. 1907. Further knowledge of some heterognathous fishes. Part II. Proceedings of the Academy of Natural Sciences of Philadelphia, 58:431-483.

Fowler, H. W. 1940. A collection of fishes obtained by Mr. William C. Morrow in the Ucayali River Basin, Peru. Proceedings of the Academy of Natural Sciences of Philadelphia, 91(for 1939):219-289.

Fowler, H. W. 1942. Los peces del Peru. Catalogo sistematico de los peces que habitan las aguas peruanas (continuacion). Boletin del Museo de Historia Natural Javier Prado, 6(22-23):352-381.

Fowler, H. W. 1945. Los peces del Peru. Catálogo sistemático de los peces que habitan en aquas peruanas. Museo de Historia Natural Javier Prado, Universidad Nacional Mayor de San Marcos, Lima, 298p.

Fowler, H. W. 1950. Os peixes de água doce do Brasil. Arquivos de Zoologia do Estado São Paulo, 6:205-404.

Fowler, H. W. 1975. A catalog of World Fishes (XXIII). Quarterly Journal of the Taiwan Museum, 28(3/4):277-401.

Garman, S. 1890. On the species of the genus Chalcinus in the Museum of Comparative Zoology at Cambridge, Mass., U.S.A. Bulletin Essex Institute, 22(1-3):1-7.

Géry, J. 1977. Characoids of the World. TFH Publications Inc., Neptune City, 672p.

Goulding, M. 1980. The fishes and the forest, explorations in Amazonian natural history. University of California Press, 280p.
Günther, A. 1864. Catalogue of the fishes in the British Museum. Trustees of the British Museum, London, vol. 5, 455p.

Günther, A. 1874. On new species of fishes. Annals and Magazine of Natural History, 14(84):453-455.

Higuchi, H. 1996. An updated list of ichthyological collecting stations of the Thayer Expedition to Brazil. Electronic version (1996) available at http://www.oeb. harvard.edu/ thayer.htm etc.

Jordan, D. S. 1919. The genera of fishes, part III. From Guenther to Gill, 1859-1880, twenty-two years, with the accepted type of each. A contribution to the stability of scientific nomenclature. Leland Stanford Junior University Publications, University Series, 39: 285-410.

Kner, R. 1858. Zur Familie der Characinen II. Sitzungsberichte Akademie der Wissenschaften, 32(2123):163-168.

Kner, R. 1860. Zur Familie der Characinen. III. Folge. Der Ichthyologischen Beiträge. Denkschriften Akademie der Wissenschaften, 18:9-62.

Kottelat, M. 1988. Authorship, dates of publication, status and types of Spix and Agassiz's Brazilian fishes. Spixiana, 11(1):69-93.

Malabarba, M. C. 1998. Phylogeny of fossil Characiformes and paleobiogeography of the Tremembé Formation, São Paulo, Brazil. Pp.69-84. In: Malabarba, L. R., R. E. Reis, R. P. Vari, C. A. S. Lucena \& Z. M. S. Lucena (Eds.). Phylogeny and classification of Neotropical Fishes. Edipucrs, Porto Alegre, 603p.

Miranda-Ribeiro, P. 1941. Notas para o estudo dos caracinídeos brasileiros. Papéis Avulsos do Departamento de Zoologia, 1(18):159-174.

Miles, R. 1947. Los Peces del Río Magdalena. Secretaria de Agricultura y Fomento del Departamento de Cali, 214p.

Myers, G. S. 1940. Suppression of Acaropsis and Chalcinus, two preoccupied generic names of South American fresh-water fishes. Stanford Ichthyological Bulletin, 1(5):170.

Nakashima, S. 1941. Algunos peces del Oriente Peruano. Boletim do Museu de História Natural Javier Prado da Universidade de San Marcos, 5(16):61-78.

Nielsen, J. G. 1974. Fish types in the Zoological Museum of Copenhagen. University of Copenhagen, Fish Types, 115p.

Ortega, H. \& R. P. Vari. 1986. Annotated checklist of the freshwater fishes of Peru. Smithsonian Contributions to Zoology, 437:1-25.

Papavero, N. 1971. Essays on the history of Neotropical Dipterology, with special reference to collectors (18701905). MZUSP, São Paulo, 2 vols, 446p.

Portugal, L. P.1990. Revisão sistemática do gênero Triportheus Cope (Teleostei, Characiformes, Characidae). Unpublished Ph.D. dissertation, Universidade de São Paulo, São Paulo, 192p.

Queiroz, H. L. \& W. G. Crampton. 1999. Estratégias para manejo de recursos pesqueiros em Mamirauá. MCT-CNPq, 
Sociedade Civil Mamirauá, Brasília,208p.

Rafinesque, C. S. 1815. Analyse de la nature, ou tableau de l'univers et des corps organisés. Palerme, 224p.

Regan, C. T. 1911. The classification of the teleostean fishes of the order Ostariophysi. 1. Cyprinoidea. Annals and Magazine of Natural History, Ser. 8, 8(43):13-32.

Ribeiro, P. M. 1941. Notas para o estudo dos Characinideos brasileiros (Peixes-gênero Chalcinus). Papéis Avulsos de Zoologia, 1(18):159-174.

Schomburgk, R. H. 1841. The natural history of the fishes of Guyana. Part I. In: Jardine, W. (Ed.). The Naturalist's library, Edinburgh, 3:126-263.

Spix, J. B. von \& L. Agassiz. 1829. Selecta genera et species piscium quos in itinere per Brasiliam annos 1817-1820 jussu et auspiciis Maximiliani Josephi I. Selecta genera et species piscium brasiliensium, $138 \mathrm{p}$.

Steindachner, F. 1876. Ichthyologische Beiträge (V). Sitzungsberichte Akademie Wissenshaften, 74(1):49-240.

Steindachner, F. 1878. Zur Fischfauna des MagdalenenStromes. Anzeiger der kaiserlichen Akademie Wissenshaften, 15(12):88-91.
Steindachner, F. 1879. Zur Fisch-fauna des MagdalenenStromes. Denkschriften classe der Kaiserlichen Akademie der Wissenshaften, 39:19-78 [Published as 1878].

Steindachner, F. 1880. Zur Fisch-Fauna des Cauca und der Flüsse bei Guayaquil. Denkschriften der kaiserlichen Akademie Wissenshaften, 42:55-104.

Steindachner, F. 1883. Ichthyologische Beiträge (XIII). Anzeiger der kaiserlichen Akademie Wissenshaften, 20(22):194-197.

Sturm, M. G. de L. \& G. de Souza. 1984. Triportheus elongatus: a new record of a characid fish from Trinidad. Copeia, 1984(1):262-3.

Travassos, H. 1951. Catálogo dos gêneros e subgêneros da subordem Characoidei (Actinopterygii-Cypriniformes). Dusenia, 2(4):273-293.

Ulrey, A. B. 1895. The South American Characinidae collected by Charles Frederick Hartt. Annals of New York Academy of Sciences, 8:257-300.
Received August 2004 Accepted November 2004 